\title{
Sedimentology and chemostratigraphy of Carboniferous red beds in the western Moncton Basin, Sussex area, New Brunswick, Canada: possible evidence for a middle Mabou Group unconformity
}

\author{
M. M. Nazrul Islam and David G. KeighleY* \\ Department of Earth Sciences, University of New Brunswick, Fredericton, New Brunswick E3B 5A3, Canada \\ *Corresponding author $<$ keig@unb.ca $>$
}

Date received: 30 November 2017 Date accepted: 12 July 2018

\begin{abstract}
The area around Penobsquis, east of Sussex, New Brunswick, Canada, is an important location of natural resources for the province. The McCully gas field produces from strata of the Mississippian Horton Group whereas younger strata of the Windsor Group are host to major potash and rocksalt deposits. Overlying these units are over $1 \mathrm{~km}$ of poorly understood red beds currently assigned to the Mississippian Mabou Group. To date, this latter unit lacks significant marker beds and has had no useful biostratigraphic recovery, despite recent extraction of close to $5 \mathrm{~km}$ of drill core. Research on this core broadly identifies siltstone and sandstone at the base of the Mabou Group that gradually coarsen up into conglomerate. The succession is considered the result of alluvial-fan progradation from the northeast. Within this succession, in several of the cores, is a single interval of localized, horizontally laminated to cross-stratified, bluish-grey sandstone, containing carbonaceous plant fragments and siltstone intraclasts. To assess the importance of this interval in the context of the red bed succession, a total of 131 samples of core from three boreholes have been analyzed using Inductively Coupled Plasma and spectroscopic techniques to determine chemostratigraphy. Study of various elemental ratios can delineate two packages, one that corresponds to the grey interval and overlying red beds, and the other to the underlying red beds. Changes in the elemental ratios are interpreted to mark a broader population of mineral species related to greater variation of provenance and diagenesis in the upper sediment package. The reduced horizons and rip-up clasts may have been produced by sediment reworking along a boundary that represents an unconformity (in core, a disconformity) at a stratigraphic level near to where one has been inferred by other workers.
\end{abstract}

\section{RÉSUMÉ}

La région entourant Penobsquis, à lest de Sussex, au Nouveau-Brunswick, au Canada, est un lieu important sur le plan des ressources naturelles pour la province. Le champ de gaz naturel McCully tire ses ressources des strates du groupe de Horton, dans le Mississippien, tandis que les strates plus récentes du groupe de Windsor recèlent d'importants gisements de potasse et d'halite. Plus d'un kilomètre de couches rouges mal comprises, actuellement attribuées au groupe de Mabou, dans le Mississippien, recouvre ce champ. À ce jour, ces couches sont exemptes d'horizon repéré significatif et n'ont fait l'objet d'aucune récupération biostratigraphique utile malgré l'extraction récente de carottes de forage totalisant près de $5 \mathrm{~km}$. Selon les recherches menées sur ces carottes, on y retrouve à la base du groupe de Mabou de grandes quantités de stiltite et de grès qui se transforment graduellement en conglomérat. Cette succession est considérée comme le résultat de la progradation d'un cône alluvial provenant du nord-est. On y a également découvert dans plusieurs carottes un intervalle localisé de grès bleu-gris à lamination horizontale à croisée, contenant des fragments de plantes carbonées et des intraclastes de stiltite. Pour évaluer l'importance de cet intervalle dans le contexte de la succession de couches rouges, 131 échantillons de carottes au total tirés de trois trous de forage ont été analysés au moyen des techniques spectroscopiques et de plasma à couplage inductif afin de déterminer la chimiostratigraphie. Létude de divers ratios élémentaires permet de circonscrire deux ensembles, un correspondant à l'intervalle gris et aux couches rouges supérieures, lautre correspondant aux couches rouges inférieures. L'interprétation des différences dans les ratios élémentaires permet ensuite de repérer une population plus marquée d'espèces minérales en lien avec une diversité accrue de provenances et une diagénèse dans l'ensemble de sédiments supérieur. Les horizons réduits et les clastes arrachés pourraient être issus du remaniement des sédiments le long d'une frontière constituant une discordance (une discordance stratigraphique dans la carotte) à un niveau stratigraphique près de l'endroit où d'autres travailleurs ont inféré pareille discordance.

[Traduit par la redaction] 


\section{INTRODUCTION}

Chemostratigraphic methods include those that characterize sedimentary successions based on distinctive features in their inorganic whole-rock geochemistry. Their applications have most commonly been in the subdivision of deformed red beds, where biostratigraphic and magnetostratigraphic methods are limited by lack of preserved microfossils and uncertain reorientation of magnetic minerals in the strata (e.g., Preston et al. 1998; Pearce et al. 1999, 2005, 2008; Ratcliffe et al. 2004, 2010).

Red beds are common in Upper Devonian to Pennsylvanian strata of southeastern New Brunswick, where they form part of the fill in a system of basins (Cocagne Graben, Moncton, Sackville, and Cumberland basins) that are components of the regional Maritimes Basin Complex (Fig. 1; Keighley 2008). Three tectono-sedimentary megacycles ("allocycles" of St. Peter 1993) have been identified (Fig. 2) that indicate a complex history of fault-controlled subsidence, strike-slip motion, basin inversion, and salt tectonics (e.g., Wilson 2005; Wilson and White 2006; Park and St. Peter 2009; Park et al. 2007, 2010; Waldron et al. 2013; Craggs et al. 2017). Red beds are particularly abundant in the $2^{\text {nd }}$ megacycle (Upper Mississippian), where they have been formally differentiated into several formations in the Moncton and adjacent basins. However, in the western part of the Moncton Basin, limited outcrop and borehole data to date have resulted only in a few broadly based studies of the Upper Mississippian red beds (Anderle et al. 1979; Wilson 2005), an informal lithostratigraphy at the sub-group level (St. Peter 1993), and continued uncertainty as to the presence or importance of a mid-red bed unconformity first inferred by Gussow (1953) and subsequently by Jutras et al. (2007) farther north in southern Québec and northern-most New Brunswick. Limited spore recovery from these red beds also has hindered biostratigraphic subdivision (St. Peter and Johnson 2009).

A recent potash exploration program by the Potash Corporation of Saskatchewan Inc. (PotashCorp), near Sussex, now has resulted in the collection of over $5 \mathrm{~km}$ of drill-core. Sedimentary logging of these cores, together with bulk-rock Inductively Coupled Plasma - Mass Spectrometry (ICPMS) analyses of 131 samples from three of the cores, allows for new insights into the red bed succession, the informal stratigraphy, and supporting evidence for the previously identified unconformity. The results further confirm the utility of whole-rock chemostratigraphy.
GEOLOGICAL SETTING

The $>3.5 \mathrm{~km}$-thick Devonian-Carboniferous stratigraphic succession in southern New Brunswick overlies terranes (southwards, Ganderia, Avalonia, and, in Nova Scotia, Meguma) that accreted to Laurentia in the Silurian-Devonian (Fig. 1). However, in this region these terranes were still subject to later relative movements accompanying oblique collision of Gondwana to Laurentia (Alleghanian orogeny, Murphy et al. 2011; Waldron et al. 2015). This provided a major transtensional-transpressional structural control on the younger stratigraphy. Initially, the result was the development of small-scale sedimentary pull-apart basins, such as the Moncton Basin (Craggs et al. 2017).

The three tectono-sedimentary megacycles recognised in the New Brunswick Devonian-Carboniferous succession (Fig. 2; St. Peter 1993) are separated by interbasinal angular unconformities related to specific tectonic episodes (Murphy et al. 2011). More localized intrabasinal unconformities are identified within individual basins. The fir st megacycle, which culminated in a late Tournaisian to early Visean inversion, consists of strata assigned to the Horton and Sussex groups. The second megacycle contains strata assigned to the Windsor and Mabou groups. The subsequent late Visean to Serpukhovian inversion (Wilson and White 2006; Murphy et al. 2011), is related to the near-continent-wide Mississippian-Pennsylvanian unconformity, and in eastern Canada is signified by a major episode of transpression and uplift associated with the Minas Fault Zone (Fig. 1a; Murphy et al. 2011). Early Pennsylvanian deposition (Cumberland Group) again appears to have been initiated in areas of transtension, and rapidly subject to salt tectonism associated with deformation of buried Windsor Group evaporites (Waldron et al. 2013; Craggs et al. 2017). However, in the later Pennsylvanian, thermal relaxation caused regional cooling and subsidence, leading to the development of an enlarged sedimentary basin, which buried most of the rapidly deposited, locally sediment-sourced, and deformed pull-apart basins. Therefore, in contrast to the first two megacycles, the third evolved to also consist of a blanket of more mature, generally more slowly accumulated sediment (Pictou Group) in a more regional terrestrial drainage sys-tem (Gibling et al. 1992).

The focus of this paper is on red beds currently included in the upper Mississippian $2^{\text {nd }}$ megacycle (Fig. 2). Within this megacycle, carbonate and evaporite rocks are interpreted to have been deposited following marine transgressions, and red beds to have followed regional uplift or marine regression (Giles 1981, 2009; Wilson 2005). Various formations are combined into the Windsor Group, the lower and upper

Figure 1. (next page) (a) General geological map of eastern Canada showing the main basement terranes and erosional remnant of the Maritimes Basin Complex (after Craggs et al, 2017). (b) Geological map of southern New Brunswick detailing the occurrence of Carboniferous strata in the Moncton Basin (after Craggs et al. 2017). (c) Map of the area east of Sussex, New Brunswick. The old mine extracted salt and potash from the northern limb of a subsurface salt diapir. Almost all gas production from the McCully field has been from beneath this limb. New salt exploration boreholes (colour coded) are located south of the diapiric axis. 


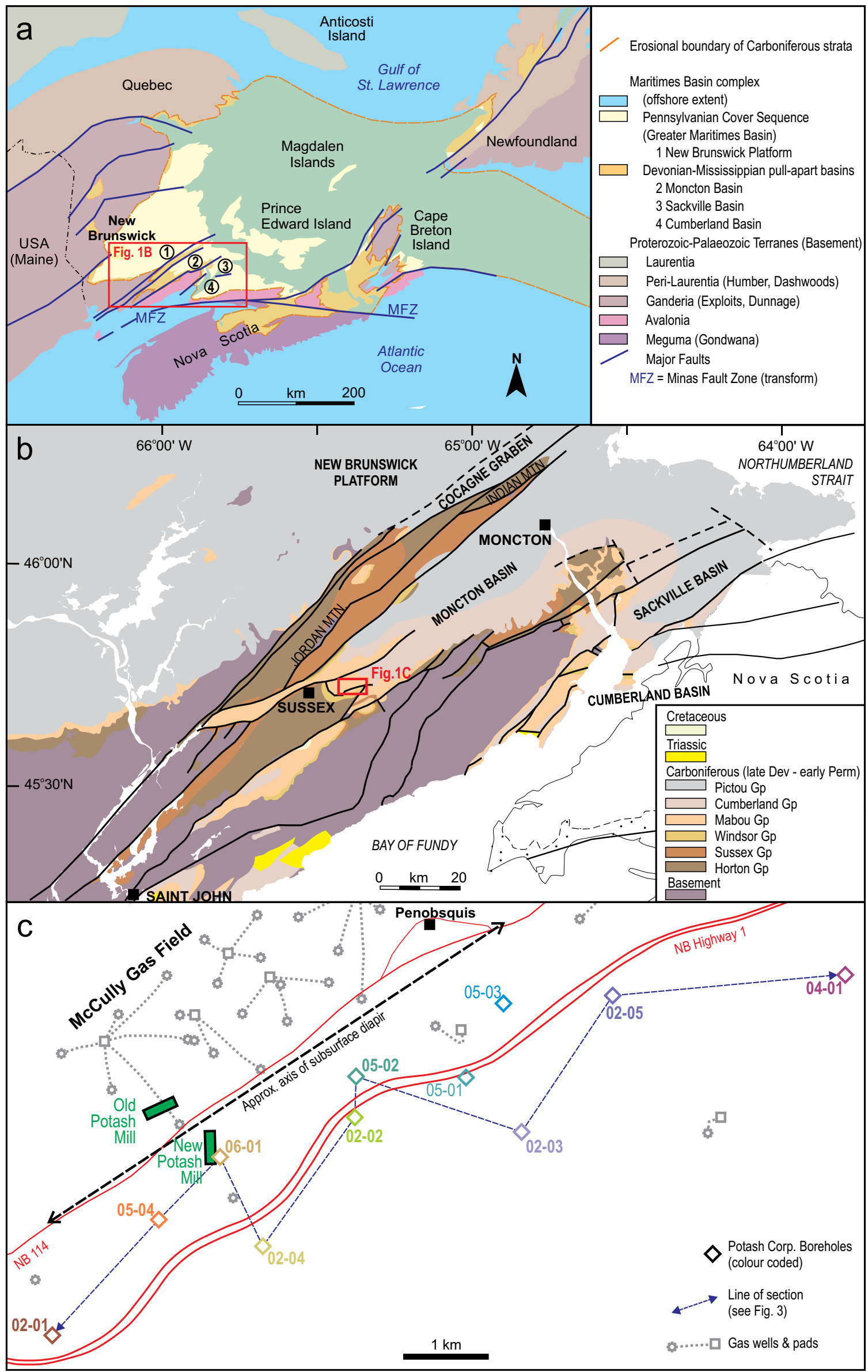




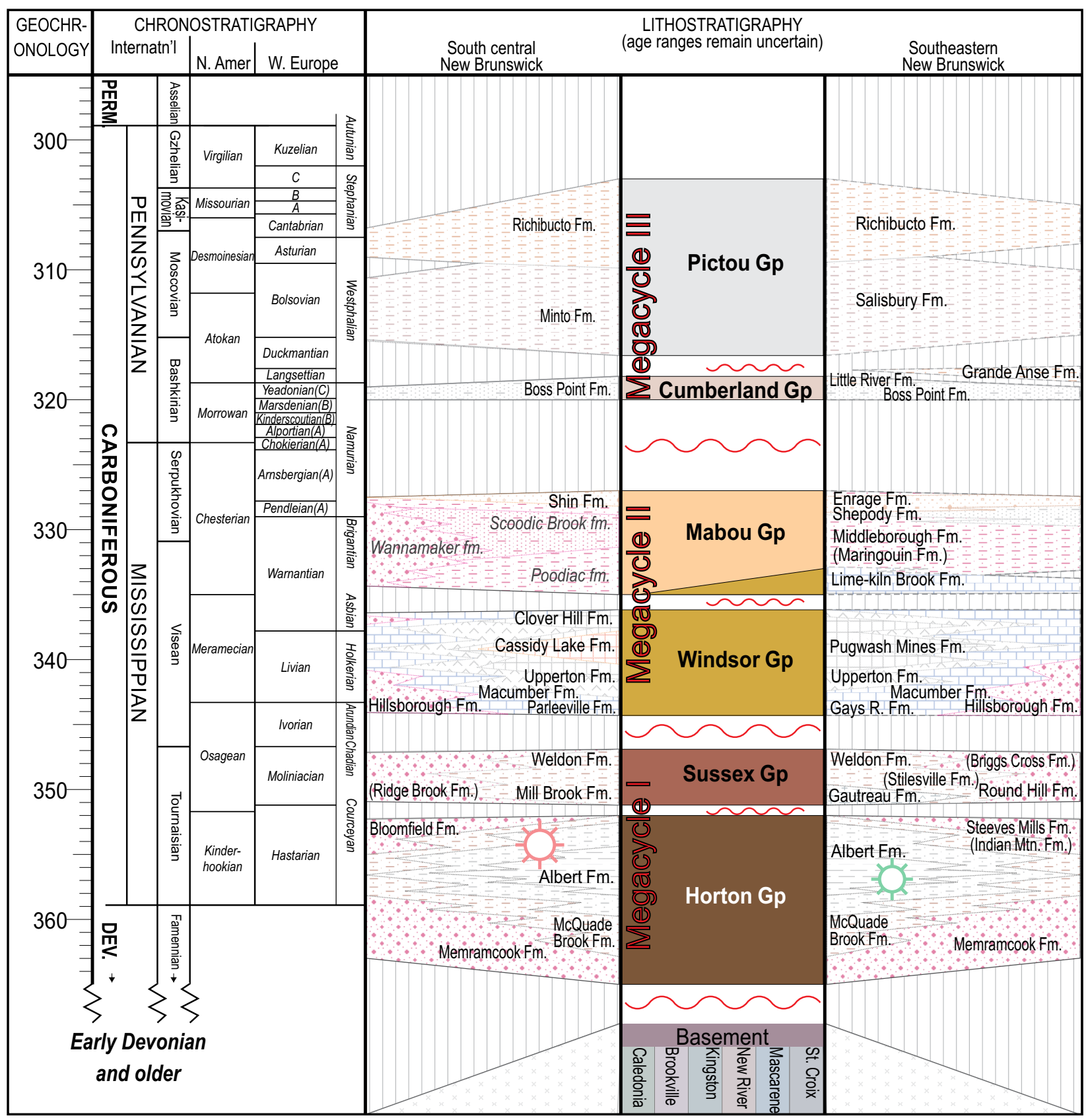

Figure 2. Stratigraphic subdivisions of southern New Brunswick including the Moncton Basin (after Keighley 2008; Craggs et al. 2017). Oil (green well symbol) and gas (red well symbol) are extracted from the Albert Formation.

contacts of which are placed at the base and top of the stratigraphically lowest and highest carbonate or evaporite beds encountered in a particular area (Giles 1981; McCutcheon 1981). In the western Moncton Basin, the uppermost Windsor Group comprises the mined potash and halite (Cassidy Lake Formation) and overlying anhydrite and halite (Clover Hill Formation, McCutcheon 1981; Wilson et al. 2006).

In Nova Scotia, additional cycles of red beds, carbonate rocks, and sulfate rocks are reported overlying Cassidy Lake equivalent strata (e.g., Giles 2009); in New Brunswick a red bed succession up to $1 \mathrm{~km}$ thick overlies the Cassidy Lake Formation (Webb 2009). Originally considered part of the
Gypsiferous Formation (Lyell 1843) or part of Division 8 of the Coal Measures (Logan 1845), and later the Bonaventure Formation (Logan 1864), these red beds in the far southeast of New Brunswick were formally assigned to the Hopewell Group and divided into three units by Norman (1941a, b) and Gussow (1953). A lower, red mudstone-dominated unit (Maringouin Formation, now Middleborough Formation, Jutras et al. 2016), is overlain by interbedded red and grey sandstone, red and grey mudstone, and minor calcareous mudstone-pebble and coalified plant-fragment conglomerate, with $\mathrm{Cu}$-mineralized horizons at the base of the unit (Shepody Formation). The uppermost red beds are inter- 
bedded conglomerate, sandstone, and mudstone (Enragé Formation). Toward the basin margins, a localized conglomeratic unit interfingers with and progressively overlies Windsor Group strata (Hopewell Cape Formation). Despite the ear-lier names noted above, for stability of nomenclature most authors (e.g., Wilson et al. 2006; Force and Barr 2006; St. Pe-ter and Johnson 2009; Utting et al. 2010; Murphy et al. 2011; Allen et al. 2013; Waldron et al. 2013; Hayward et al. 2014; Holt et al. 2014; Stimson et al. 2016; Craggs et al. 2017) in-clude these and laterally equivalent red bed units sitting on Windsor Group strata in the Mabou Group of Belt $(1964,1965)$. Overlying plant-bearing grey sandstone, mudstone, and thin coal beds are assigned to the Boss Point Formation (Cumberland Group, Pennsylvanian).

In the Sussex region, the informal units of Anderle et al. (1979) have been used for the post-Windsor red beds, namely: grey and reddish brown sandstone, siltstone, and minor conglomerate for the Poodiac formation; greyish red conglomerate, and minor sandstone and siltstone for the Wanamaker formation; and red siltstone, and fine sandstone for the Scoodic Brook formation (note that, following the North American Commission on Stratigraphic Nomenclature, 1983, informal names do not warrant capitalization of "formation").

There has been much debate regarding the nature of the contacts associated with the post-Windsor red beds. Gussow (1953) proposed that a "mid-Hopewell" unconformity separating the Shepody and Enragé formations was equivalent to the Mississippian-Pennsylvanian boundary. As evidence, in a seismic-based cross-section (adjacent to the current study area) he interpreted Shepody-involved thrust faulting to be regionally truncated by overlying Enragé Formation. This latter formation, and its equivalent Claremont Formation in Nova Scotia, also have been assigned to the overlying (i.e., $3^{\text {rd }}$ megacycle) Pennsylvanian Cumberland Group by Ryan and Boehner (1994). More recent seismic interpretations identify "a local intra-Mabou unconformity" adjacent to a thrust-related triangle zone, with Gussow's regional Mississippian-Pennsylvanian boundary unconformity picked at the Enragé - Boss Point contact (Wilson and White 2006). This latter contact for the Mississippian-Pennsylvanian boundary is also supported by the palynological work of Utting et al. (2010).

In Québec, Jutras et al. (2001) noted a channelized disconformable contact between underlying red clastic rocks of the type Bonaventure Formation and the overlying plant-bearing grey clastic rocks of the Pointe Sawyer Formation. Although lacking biostratigraphic control, the underlying red beds were considered time equivalent to the upper Windsor Group strata of Nova Scotia and named the Percé Group by Jutras and Prichonnet (2005). As noted above, this splitting of the red beds has not been adopted by other workers in New Brunswick and Nova Scotia.

\section{METHODS}

Drill cores (2.5 inch, or $63.5 \mathrm{~mm}$, diameter) from the 2002, 2005, and 2006 PCS exploration program were selected. From southwest to northeast of the study area (Fig. 1c) these holes are named: PCS-02-01, PCS-05-04, PCS-02-04, PCS-06-01, PCS-02-02, PCS-05-02, PCS-02-03, PCS-02-05, and PCS-04-01. Cores from PCS-05-01 and PCS-05-03 were excluded from detailed lithofacies analysis because they are highly fractured. Logging of the approximately $4 \mathrm{~km}$ of core was undertaken at the centimetre scale from the depth where coring began in the red beds, down to the contact with underlying evaporite or carbonate; study of Windsor Group strata did not form part of this project. Lithofacies analysis was based on the classification scheme of Miall (1978, 1996).

A small biostratigraphic study was attempted on material from grey siltstone beds but no palynologic components were identified that could narrow down the time of deposition beyond what is already known and stated above (G. Dolby, personal communication, 2013).

Several of the logged boreholes were also selected for geochemical sampling. For PCS-02-05, 59 samples were collected systematically at regular $(\sim 10 \mathrm{~m})$ intervals. For boreholes PCS-05-04 $(\mathrm{n}=44)$ and PCS-02-01 $(\mathrm{n}=30)$, samples were collected by random number generation (converted to borehole depth) using Microsoft Excel to achieve more unbiased results. In all cases, to minimize variation resulting simply from grain size factors (Pearce et al. 1999), materials were collected from the finest grained beds within $1 \mathrm{~m}$ of the designated sampling depth.

Following Pe-Piper et al. (2008), sample preparation and analyses were performed by Activation Laboratories Ltd. (Actlabs) in accordance with the International Organization for Standardization (ISO) 17025. Preparation procedures are detailed on the Actlabs website (Activation Laboratories Ltd. 2014). Powdered and fused samples were analyzed by Perkin Elmer Sciex ELAN 6000, 6100 or 9000 ICP/MS, and samples from each core were randomized prior to analysis. Three blanks and five controls (three before the sample group and two after) also were analyzed per group of samples. Control samples included standards NIST694, DNC-1, and BIR-1a for major elements, and OREAS 100a and 101a, NCS DC 86312, 70009, and 70014 for minor and trace elements. The relative standard deviation from replicate analyses of the standard is $<5 \%$ for major elements and $<10 \%$ for minor/trace elements. The uncertainty associated with various determinations is $\pm 100 \%$ at the detection limit (DL), $\pm 15 \%$ at $x 10$ DL and $\pm 5 \%$ at x100 DL. Duplicates were fused and analyzed every 15 samples with instrument recalibration after every 40 samples.

Analyses of the different cores were run several months apart. Although the same standards were run with each analysis, and quality control checks indicate consistent readings, during statistical analyses we follow Tuttle et al. (1983) and do not combine data from different cores into single datasets. 
In whole-rockgeochemical data, variablesarenon-negative and compositional in nature; values are recorded as a proportion of the whole, i.e., ppm or percent (\%). This constrained sample space, or the simplex, leads to what is known as the constant sum problem, which together with an often non-normal distribution of the data, makes basic statistical analyses (e.g., variance, correlation, regression and its derivatives) inapplicable (Pearson 1896; Chayes 1960; Butler 1979; Davis 2002). It also means that the compositional variables are, in fact, ratios whose denominators are rarely the sum of all the constituents available to be measured (Davis 2002). To overcome this problem, Aitchison (1986) demonstrated that centred log ratio (CLR) data transformation allows for the use of standard statistical methods on such geochemical data (Can Mert et al. 2016). This transformation is a simple process done by taking the natural log of each quotient where each compositional variable is divided by the geometric mean of the composition. Elements with more than one recorded value below detection limit remain problematic. For elements with only one such value (cobalt, zinc, germanium, tin, thallium), an artificial value (v) was assigned for statistical purposes, where $\mathrm{v}=\mathrm{x}-(\mathrm{x} / 10)$ and $\mathrm{x}=$ detection limit (Davis 2002). Elements with more than one value below detection limit were excluded from statistical analyses. The raw data (in ppm) are provided in Appendix A.

\section{SEDIMENTOLOGY}

Sedimentological analysis of red bed cores taken from most of the recent vertical PCS exploration boreholes (Figs. $1 c, 3,4)$ resulted in the identification of 11 major lithofacies (Table 1). Lithofacies are mainly reddish-brown, pale brown, brownish-grey, and brown; ferruginous or calcareous; and mainly horizontally stratified. A unique bluish- or brownishgrey sandstone interval containing rip-up clasts and/or plant fragments occurs in the lower parts of most boreholes. The summary sedimentological logs (Fig. 3) indicate that finegrained and/or sandstone-dominated facies broadly coarsen upward to gravel facies, with the amount of coarse-grained sediment also increasing toward the northeastern part of the study area. Accordingly, four intervals, the lower red sandstone-siltstone interval, bluish-grey sandstone interval, upper red sandstone-siltstone interval, and red polymictic conglomerate interval, have been identified. They are briefly reviewed in terms of their lithofacies associations. Also for brevity, since limited information is preserved in core (e.g., lateral facies relationships and larger scale geometries are not present to narrow down an interpretation), a plethora of possible conditions exist under which these various sedimentary structures are deposited, and a comprehensive discussion of all the possible interpretations is not feasible: only our favoured interpretations are presented.

\section{Lower red sandstone-siltstone interval}

Description: This interval comprises pale brown to greyish- brown, very fine- to fine-grained sandstone and siltstone, with rare scattered thin greenish- or bluish-grey bands and blotches. The beds were observed to have dips of $\sim 5$ to $\sim 20$ degrees. The maximum core thickness of this interval is $\sim 220$ $\mathrm{m}$ in PCS-05-04 (in the southwestern part) with a minimum thickness of $\sim 97 \mathrm{~m}$ in PCS-04-01 at the northeast corner of the study area. Packages of sandstone beds range in thickness from $\sim 0.5 \mathrm{~m}$ to $\sim 27 \mathrm{~m}$, and siltstone packages from $\sim 2 \mathrm{~m}$ to $\sim 33 \mathrm{~m}$. Individual packages both coarsen and fine upward; however, the interval shows an overall coarseningupward trend (except PCS-02-04). The most commonly identified lithofacies are Sh, Sx, Sp, Fl, and Fm, with lithofacies St, Sm, and Fd subordinate. Scattered nodular carbonate and sulfate concretions are also present. Cross-laminations in lithofacies Sx are mostly asymmetric and rarely display climbing. Mudstone rip-up clasts, identified in places in sandstone packages, are light brown to dark brown, subangular to subrounded, and elongate. Such clasts may also be present in rare, thinly interbedded polymictic conglomerate of core from the northeastern boreholes.

Interpretation: The colour of the intercalated sandstone and siltstone unit is evidence of subaerial exposure and a low water table in a predominantly oxidizing environment (Walker 1967; Abdul Aziz et al. 2003; Spalletti and Pinol 2005). Horizontally stratified sandstone (Sh) is interpreted as evidence of high energy flow (i.e., upper plane bed), probably associated with flooding events (Miall 1977; Khalifa et al. 2006; Türkmen et al. 2007). Cross-stratified facies (i.e., Sx, Sp, and St) commonly indicate the waning stage of flooding and decreasing velocity of flows towards lower flow regime conditions (Spalletti and Pinol 2005; Khalifa et al. 2006; Hadlari et al. 2006). Asymmetric current ripples were produced by unidirectional current (Chakraborti et al. 2009; Köykkä 2011), and the climbing shape of these ripples indicates high rates of aggradation (Collinson 1996). Finegrained facies (i.e., Fl and Fm) represent deposition mostly from suspension (Hadlari et al. 2006; Köykkä 2011).

Structureless or massive sediments (i.e., Sm and Fm) are interpreted as having formed under conditions of high rates of suspension settling from currents of moderate to high sediment concentration (Abdul Aziz et al. 2003; Spalletti and Pinol 2005). Other possibilities exist but are less likely. For example, animals and plants are known to have colonized the local landscape by Mississippian times (e.g., Keighley and Pickerill 1994, 2003; Falcon-Lang 2004). Thus, massively bedded siltstones might indicate complete bioturbation of the substrate (Rhoads 1967), but there is no instance of partly bioturbated beds with distinct burrows or roots to suggest soil-forming activity, which would be an odd dichotomy.

Soft-sediment deformations (Fd) indicate release of excess pore-water pressure or dewatering (Spalletti and Pinol 2005). Siltstone rip-up clasts are interpreted as a record of high energy flooding and reworking of previously deposited mudstone (Spalletti and Pinol 2005; Köykkä 2011). Interbedded sandstone units indicate deposition from unidirectional water flow of both waning velocity (fining-up beds, 

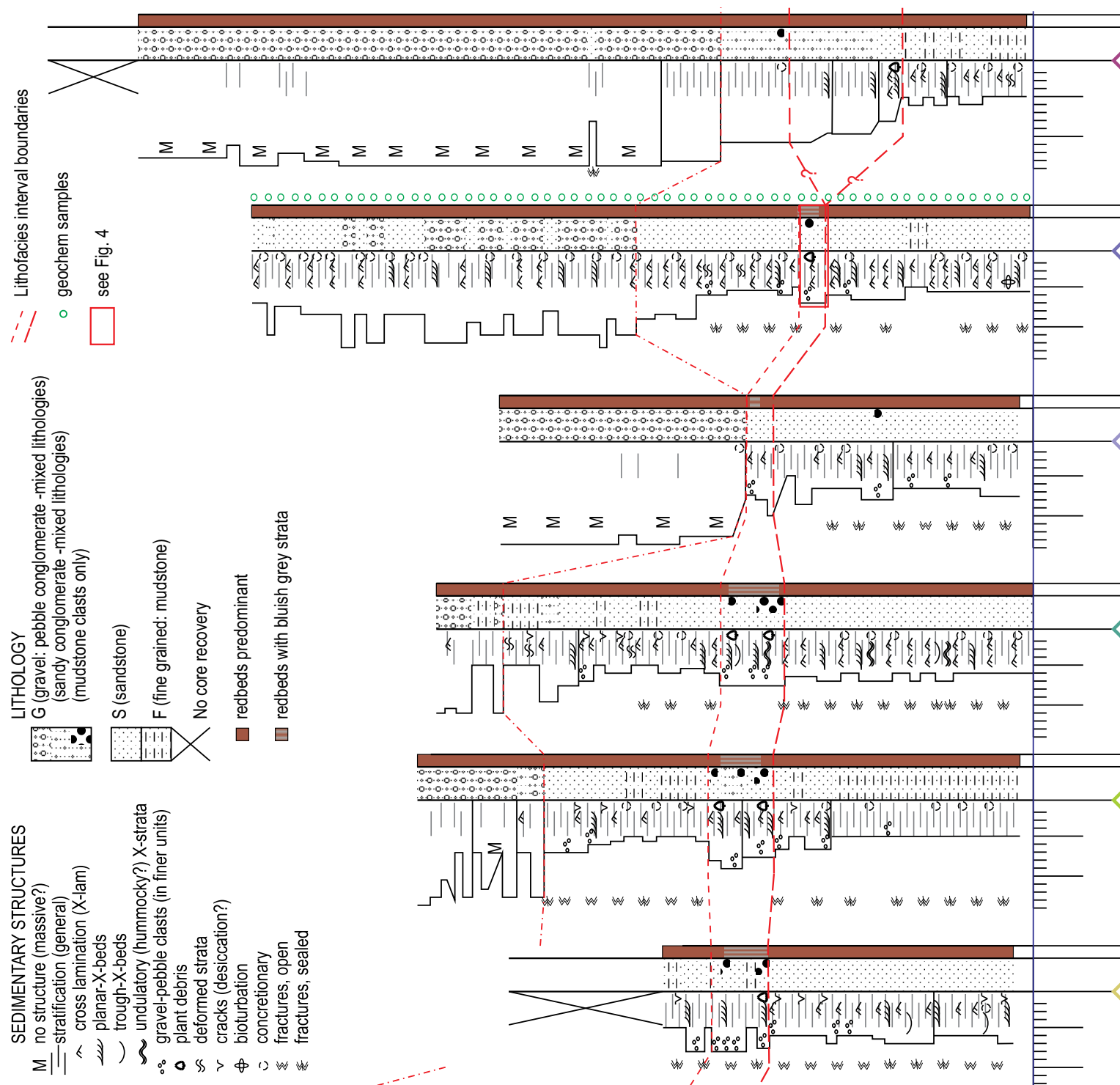
e.g., McEwen et al. 2011) and increasing velocity (coarsening-up beds, e.g., Heward 1978). The presence of siltstone rip-up clasts indicates downcutting into intraformational sediment, which could be considered evidence of upstream channelization. The small core diameter and many core breaks at the contact between sandstone and mudstone preclude confirmation of downcutting and channelization (i.e., fluvial flow). Although coarsening-upward profiles could represent, for example, prograding fan lobes, crevasse splays, or avulsion belts, they can also be related to base-level changes (Türkmen et al. 2007). Collectively this association of sandstone and intercalated siltstone favours a braidplain or distal alluvial fan setting. Laminated red bed mudstone, with rare nodular carbonate and sulfate but no bioturbation and rhizoconcretions, suggest harsh terrestrial conditions in the floodplain environment: regolith, but no paleosol, development.

\section{Bluish-grey sandstone interval}

Description: This interval is composed of gently dipping (up to 20 degrees) pale brown, brownish-grey, bluish-grey, or mottled grey-brown, occasionally pebbly, fine- to coarsegrained (dominantly medium-grained) sandstone and siltstone. Unlike the under- and overlying intervals, the grey strata may be metre scale in thickness. In the western part of the study area, the thickness of this interval is $\sim 75 \mathrm{~m}$ in PCS06-01 and PCS-02-04, but $<20 \mathrm{~m}$ in PCS-02-03 (middle part of the study area). The thickness of the measured sandstone packages range from $\sim 0.5 \mathrm{~m}$ to $\sim 12 \mathrm{~m}$ and siltstone packages range from $\sim 1 \mathrm{~m}$ to $\sim 4 \mathrm{~m}$. Both coarsening- and finingupward packages are identified (but rarely at the scale that can be illustrated in the summary logs, Fig. 3); however, the interval typically shows an overall coarsening-upward trend (only PCS-02-03 shows a distinct fining-upward trend). The major lithofacies identified are Sh, Sx, and Sp with Fl, St, $\mathrm{Sd}$, and $\mathrm{Fm}$ as subordinates. Cross-laminations or ripple cross-laminations $(\mathrm{Sx})$ are asymmetric in profile. Coalified plant fragments (Fig. 4b) are unique to sandstone of this interval, and they were observed in most cores (not PCS-0504 and PCS-02-03). Except for PCS-02-03 and PCS-04-01 (northeastern part of the study area), some sandstone also contains mudstone rip-up clasts of a size that can exceed the diameter of the core. Where occurring discretely, these clasts are grey, light brown or dark brown, angular to subrounded, and typically elongate (Fig. 4d). Again, such clasts may also be one component of several in rare, thinly interbedded polymictic conglomerate that occurs in the northeastern boreholes.

Interpretation: Broadly, the lithofacies association in this interval is little different from that of the underlying lower red sandstone interval. However, the more extensive grey colour of sediment and the preservation of organic matter suggest waterlogged conditions were sufficiently prevalent that organic, likely plant, matter was preserved, and oxidation of iron did not progress far enough to form haematite (Wright and Sandler 1994; Collinson 1996; Abdul Aziz et al. 2003). However, no roots, burrows, or other clear indicators of palaeosol are present.

Across the study area, this interval can be considered to mark a shift to a more permanently high-water table and thus a relative rise in base level, but otherwise still a braidplain or distal alluvial fan setting. The cause of this rise may be the result of one or a combination of factors; rising lake or sea level (eustacy), tectonism resulting in either relative lake-/sea-level rise, or drainage basin reorganization, a wetter climate. This is further discussed below.

\section{Upper red sandstone-siltstone interval}

Description: This interval is of gently dipping ( $\sim 5$ to $\sim 30$ degrees), reddish-brown, pale brown, and brown, very-fine- to fine-grained sandstone and siltstone, with coarse-grained sandstone also present in PCS-02-05 and PCS-04-01. As in the lower interval, thin greenish- or bluish-grey bands and blotches are irregularly present. In the western part of the study area the interval is $\sim 300 \mathrm{~m}$ thick (PCS-06-01), but much thinner (i.e., $\sim 10 \mathrm{~m}$ in PCS-02-03, $\sim 40 \mathrm{~m}$ in PCS-04$01)$ in the middle and northeastern parts of the study area. The thickness of the measured sandstone packages ranges from $\sim 0.5 \mathrm{~m}$ to $\sim 15 \mathrm{~m}$. As previously, both coarsening- and fining-upward packages are identified. Similarly, the interval shows an overall coarsening-upward trend in most boreholes (Fig. 3). Sandstone predominates in most cores, except for PCS-06-01, PCS-05-04, and PCS-02-04 (western and southwestern part of the study area) where siltstone is dominant. In the sandstone, lithofacies Sh, Sx, Sp, and subordinate $\mathrm{Sm}$ are recognized; Fl, Fm, and subordinate $\mathrm{Fd}$ are the commonly identified lithofacies in the siltstone. Again, cross-laminations $(\mathrm{Sx})$ are mostly asymmetric in shape, with climbing cross-laminations identified in PCS-02-01, PCS06-01, and PCS-05-02. Mudstone rip-up clasts, identified rarely in sandstone packages and also in thinly interbedded polymictic conglomerate, are light brown to dark brown, subangular to subrounded, and elongate.

Interpretation: This interval is considered to be similar to the distal alluvial fan to floodplain facies association described for the lower red interval, and represent a return to arid, ephemeral flow conditions in the study area. However, predominance of siltstone in the western and southwestern parts of the study area is inferred to represent waning of flood flow followed by suspension deposition (Hadlari et al. 2006; Köykkä 2011).

\section{Red polymictic conglomerate interval}

Description: This interval is not recorded in logged cores from PCS-02-01 and PCS-02-04 (in the southwestern part), and increases in thickness to over $500 \mathrm{~m}$ in PCS-04-01 in the northeastern end of the study area (Fig. 3). The gently dipping beds (up to $\sim 25$ degrees) comprise conglomerate packages that are up to $\sim 58 \mathrm{~m}$ thick, sandstone packages up 

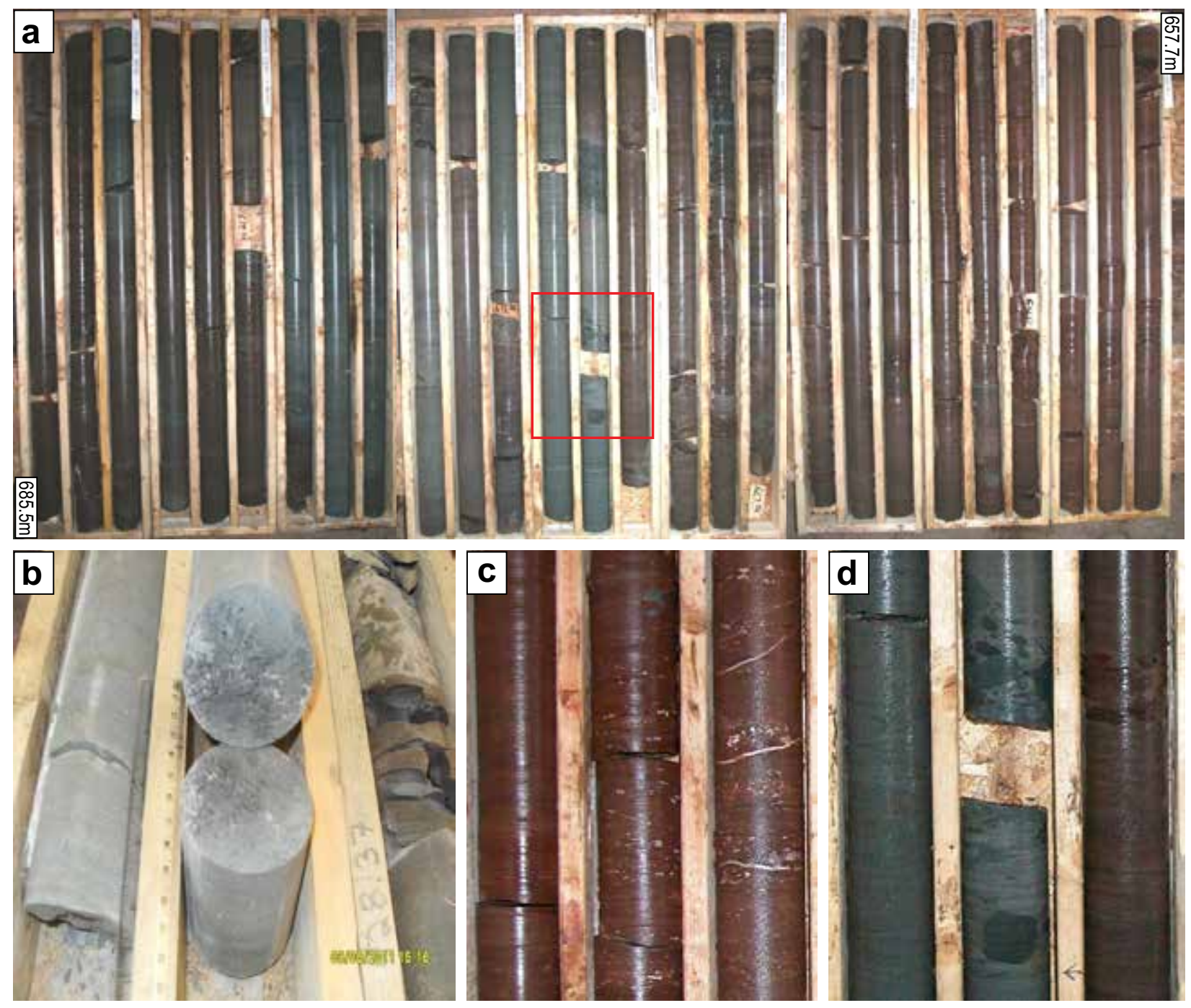

Figure 4. Images of PotashCorp core from the Penobsquis area of New Brunswick. All core is 2.25 inches diameter (for scale). (a) Example of a complete core interval through the Bluish-grey Sandstone Interval, borehole 02-05. (b) Abundant coalified plant debris preserved on bedding planes (broken core slabs) in the Bluish-grey Sandstone Interval, 02-01. (c) Calcite-sealed fractures and calcareous concretions within the Upper Red Sandstone-Siltstone interval, 02-01. (d) Detail of mudstone rip-up clasts from the area shown in the red rectangle in $4 \mathrm{~A}$.

to $\sim 14 \mathrm{~m}$ thick, and siltstone packages up to $\sim 7 \mathrm{~m}$ thick. As with the other intervals, both coarsening- (dominant in this case) and fining-upward sequences exist at different scales. The conglomerate is composed of granule- to pebble-sized, poorly sorted, subangular to subrounded polymictic clasts. Felsic igneous rocks and metamorphic rocks (e.g., schist, gneiss) are the most commonly identified clast types; mudstone clasts also occur. Matrix-supported conglomerate predominates over clast-supported conglomerate (only identified in PCS-02-03, PCS-02-02, and PCS-05-04). The conglomerate matrix typically consists of reddish-brown to pale brown and medium- to very-coarse-grained sandstone. The commonly identified lithofacies within this interval are Gmg, Gcm, and Sh; subordinate lithofacies are Sx, Sp, and Fm. Asymmetric cross-laminations or ripple cross-laminations (Sx) were identified only in PCS-02-05 and PCS-05-02.
Interpretation: Matrix-supported conglomerate (Gmg) indicates deposition from debris flows where they moved as dense masses and the matrix strength was large enough to transport the clasts (Blair and McPherson 2009). Clast-supported conglomerate $(\mathrm{Gcm})$ is also considered the product primarily of debris flows, rather than fluvial flow, because of the combined lack of imbricate pebbles, cross stratification, and erosion surfaces within beds (Blair and McPherson 1992; Martins-Neto 1996; Sohn et al. 1999), although these absences might simply be a function of observations being restricted by the narrow core diameter. The angularity of the clasts indicates deposition probably close to the source (Köykkä 2011). The poor sorting and polymictic nature indicate that there were a variety of sources for the clasts (Veevers et al. 2007). Gravel beds separated by discontinuous lithofacies Sh, Sp, and Sx indicate that deposition of the 
sand occurred within gravel frameworks by sediment-laden aqueous currents (Hadlari et al. 2006). Rare fine-grained sediment $(\mathrm{Fm})$ suggests that distinct flow events alternated with low energy fallout deposits of episodic floods (Spalletti and Pinol 2005). Thicker bedded conglomerate to the northeast indicates that the alluvial fan apex was located in this direction. Overall coarsening- and thickening-upward sequences suggest active alluvial fan progradation and outbuilding (Heward 1978; Türkmen et al. 2007).

\section{CHEMOSTRATIGRAPHY}

The grey sandstone interval is a distinct stratigraphic marker in the study area, the base of which, as interpreted, marks a shift in depositional conditions. The bulk geochemical data collected (from PCS-02-01, PCS-05-04, and PCS-02-05) can be used to statistically test whether the base of the grey sandstone interval is also a distinct chemostratigraphic horizon. Simply, for comparison of variances and mean values, the null hypothesis can be tested against its opposite:

$$
\begin{aligned}
& \mathrm{H}_{\mathrm{o}}: \mathrm{H}_{\text {upper interval }}=\mathrm{H}_{\text {lower interval }} \text { against } \\
& \mathrm{H}_{1}: \mathrm{H}_{\text {upper interval }} \neq \mathrm{H}_{\text {lower interval }}
\end{aligned}
$$

where below the base grey sandstone interval is considered as 'lower interval', and the base grey sandstone interval and above are considered as 'upper interval'. Significance was set at $\alpha=0.05$ in all analyses. Differences in correlation coefficients and simple regression equations (with $\mathrm{SiO}_{2}$ as the explanatory variable) provide additional comparisons.

Geochemical data can be presented in different ways, including simple plots of specific elements against depth or location, and scatter plots (Harker diagrams and discriminant plots) of two elements or two computed groups of elements, e.g., to identify provenance. In the selected plots presented herein (Figs. 5 to 9), data from the lower interval are coloured blue, and data from above the base of the grey sandstone interval are coloured red.

\section{Provenance}

Results: The provenance diagrams of Roser and Korsch (1988) were developed from a principal component analysis of several major elements measured from sandstone and mudstone of readily determinable provenance. The plots of provenance for the Sussex boreholes indicate that the red beds are of mixed quartzitic, felsic, and rare intermediate source (Fig. 5). They also suggest a difference between upper and lower interval samples. Materials from the lower interval are more tightly constrained and plot to the lower right of the data from the upper interval. The plots also suggest that the distinction might be most pronounced in the material from core PCS-02-05. It appears that these provenance graphs were first constructed using non-transformed data and so statistical analyses to test the similarity of upper and lower intervals were not performed using our data. Instead, the suggestion of a difference between the upper and lower interval is further investigated using transformed (centered log ratio) data of paired elements below. These further investigations are undertaken critically because Pe-Piper $e t$ al. (2008) noted that bulk geochemical approaches to provenance analysis of the terrigenous sedimentary rocks lack a globally applicable set of element discriminants.

Interpretation: The provenance plots are indicative of a more restricted suite of minerals, which consist of a higher mafic component, in the lower interval relative to the upper interval. Also, such a distinction may be more pronounced in the more proximal, NE part of the study area.

$$
\mathrm{SiO}_{2}: \mathrm{Al}_{2} \mathrm{O}_{3}
$$

Results: For $\mathrm{SiO}_{2}$ plotted against $\mathrm{Al}_{2} \mathrm{O}_{3}$, the raw data from the Sussex boreholes indicate that $\mathrm{Si}$ and $\mathrm{Al}$ are the two dominant elements, representing between $65 \%$ and $85 \%$ of the total composition (Fig. 6a). The four outliers, from PCS-05-04, represent the samples with the highest $\mathrm{Ca}$ abundance. For the transformed data, a significant difference in the variance of the Si:Al ratios between the upper and lower intervals is identified only in PCS-02-05 (all lithologies combined, Fig. $6 c)$. However, with the exception of the upper interval in PCS-02-05, there is a significant negative correlation both in the upper and lower intervals. A similar pattern is present when the data are subdivided on lithologic character (Figs. $6 \mathrm{~d}$ to $\mathrm{k}$ ). The random sampling program did not result in sufficient mudstone samples for statistical analysis.

Interpretation: Silica $(\mathrm{Si})$ and aluminum $(\mathrm{Al})$ are major elements in many of the same common sedimentary minerals, in a ratio of $\sim 3: 1$ for K-feldspars and $\sim 1: 1$ for anorthite or kaolinite. A mix of kaolinite and K-feldspar, or of other clays and micas (typically also with Si:Al ratios between 3:1 and 1:1) in different samples would give increasing scatter somewhere between 3:1 and 1:1. However, some common Si-bearing minerals lack Al, e.g., quartz, zircon, and titanite. Samples also containing an increasing proportion (with respect to the Al-silicates) of these latter minerals would plot closer to the Si axis and produce even greater scatter. Therefore, viewing the data as a whole, the red beds can be considered a mix primarily of Si-minerals and subordinate alumino-silicate minerals.

Elemental abundances are typically reported as weight

Figure 5. (next page) + Classification plots of discriminant functions $\mathrm{F} 1\left(-1.773 \mathrm{TiO}_{2}+0.607 \mathrm{Al}_{2} \mathrm{O}_{3}+0.76 \mathrm{Fe}_{2} \mathrm{O}_{3}(\mathrm{~T})-1.5 \mathrm{MgO}+\right.$ $\left.0.616 \mathrm{CaO}+0.509 \mathrm{Na}_{2} \mathrm{O}-1.224 \mathrm{~K}_{2} \mathrm{O}-9.09\right)$ and $\mathrm{F} 2\left(0.445 \mathrm{TiO}_{2}+0.07 \mathrm{Al}_{2} \mathrm{O}_{3}-0.25 \mathrm{Fe}_{2} \mathrm{O}_{3}(\mathrm{~T})-1.42 \mathrm{MgO}+0.438 \mathrm{CaO}+\right.$ $\left.1.475 \mathrm{Na}_{2} \mathrm{O}+1.426 \mathrm{~K}_{2} \mathrm{O}-6.861\right)$ for the red beds in the study area. Data indicate mixed quartzitic, felsic and rare intermediate sources. Provenance fields are from Roser and Korsch (1988). 
F2

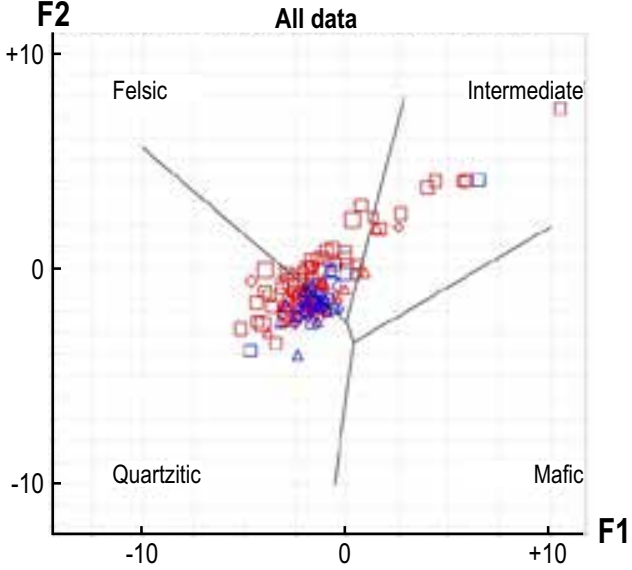

02-05 (NE) All lithologies

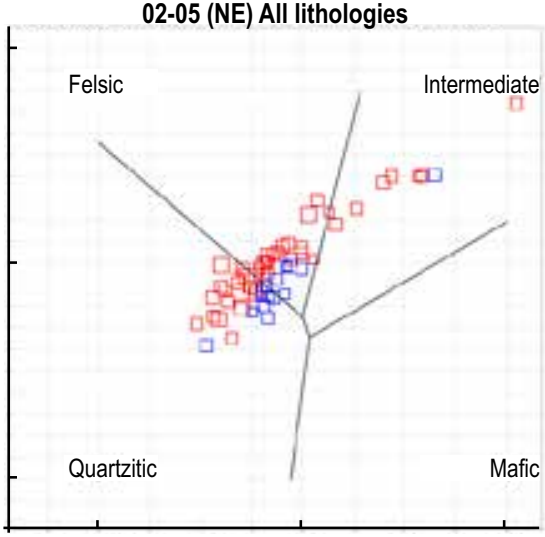

05-04 All lithologies

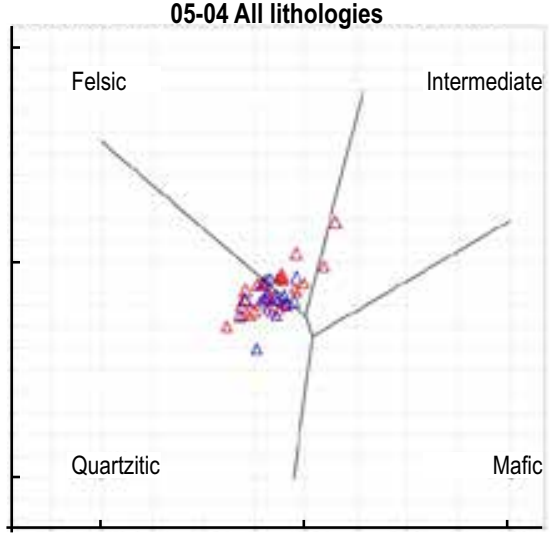

02-01 (SW) All lithologies

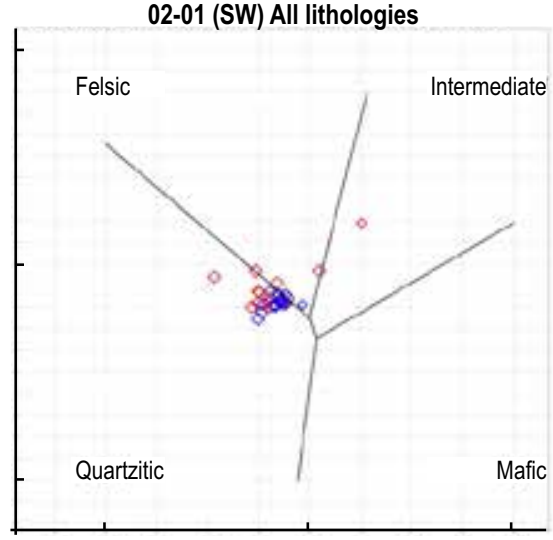

\section{F1}

\section{Legend}

$\diamond$ lower, 02-01, sandstone $\diamond$ upper, 02-01, sandstone

$\diamond$ lower, 02-01, mudstone $\diamond$ upper, 02-01, mudstone

$\square$ upper, 02-05, conglomerate

$\square$ lower, 02-05, sandstone $\quad \square$ upper, 02-05, sandstone

口 lower, 02-05, mudstone $\quad$ upper, 02-05, mudstone

$\Delta$ lower, 05-04, sandstone $\quad \Delta$ upper, 05-04, sandstone

$\Delta$ lower, 05-04, mudstone $\quad \Delta$ upper, 05-04, mudstone
02-05 (NE) Sandstone

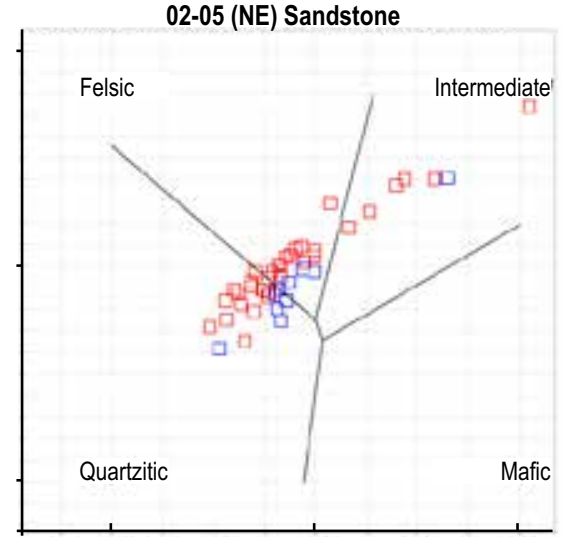

05-04 Sandstone

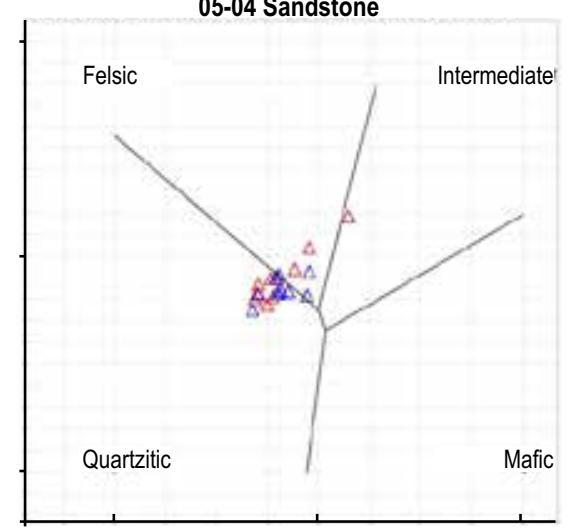

02-01 (SW) Sandstone

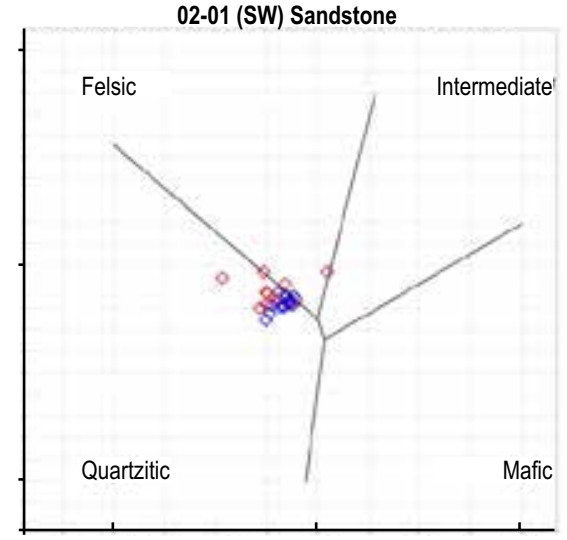

02-05 (NE) Mudstone

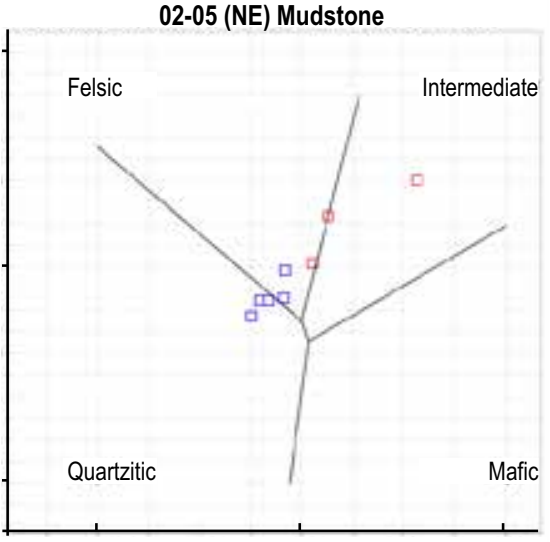

05-04 Mudstone

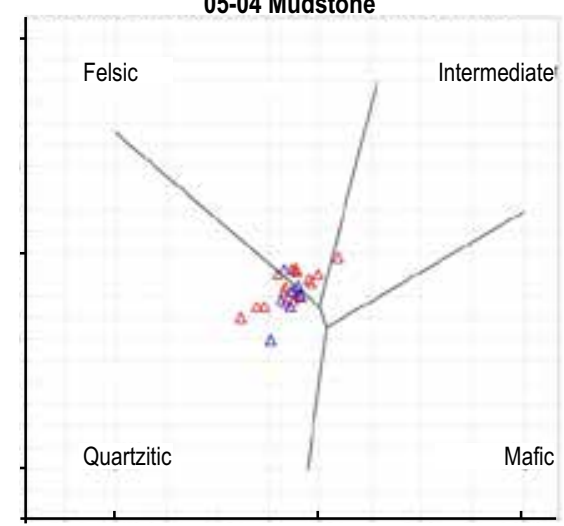

02-01 (SW) Mudstone

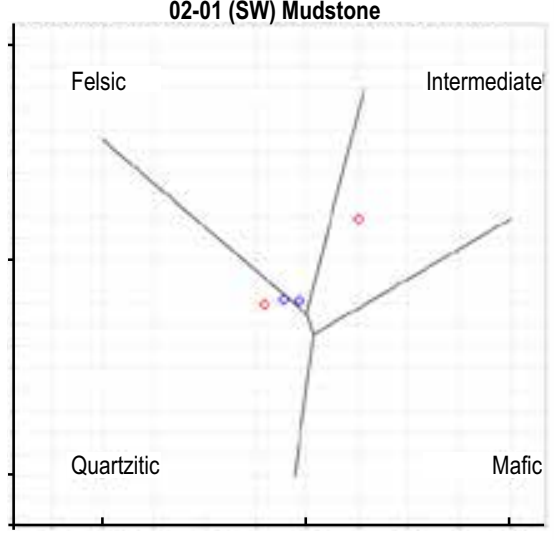


(a) All data (raw compositional)

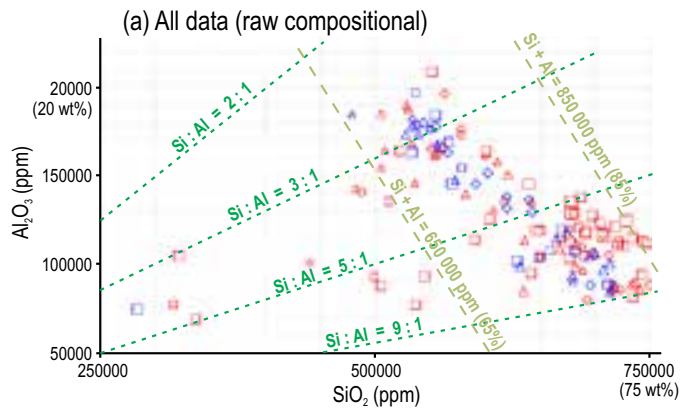

(c) 02-05 [NE] All (clr transformed)

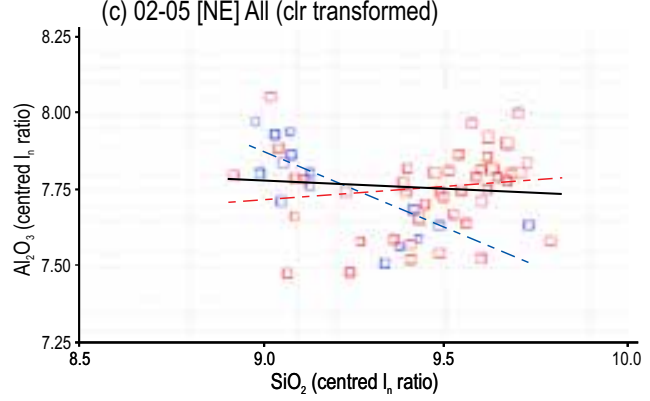

(e) 05-04 (clr transformed)
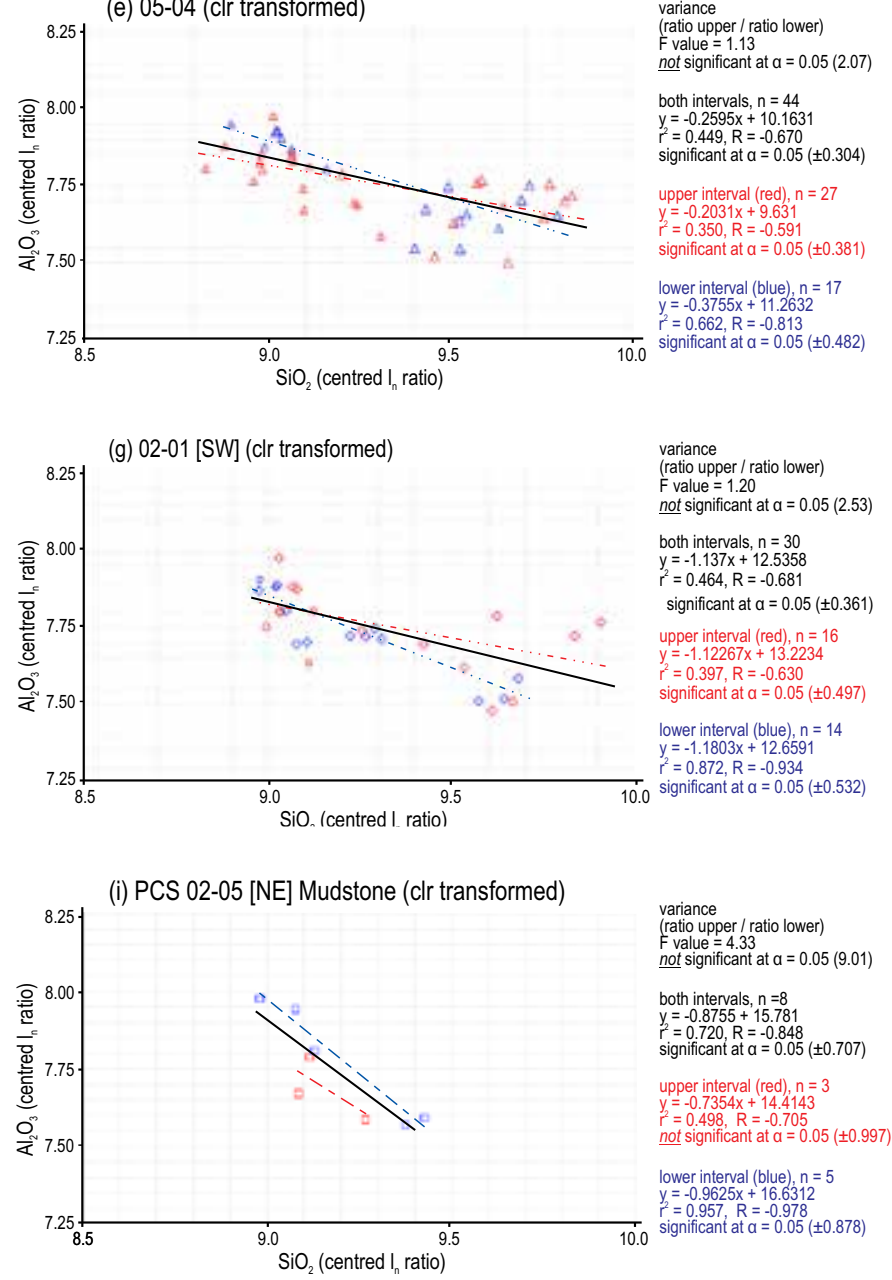

proportions (in \% or $\mathrm{ppm}$ ), and so are subject to the constraint: $\mathrm{x}_{\mathrm{Si}}+\mathrm{x}_{\mathrm{Al}}\left(\ldots+\mathrm{x}_{\mathrm{D}}\right)=100 \%$ (Aitchison 1986). For non-transformed data, the sample space is confined below

variance
(ratio upper / ratio lower)
$F$ value $=1.13$ not significant at $\alpha=0.05(2.07)$

both intervals, $n=44$ $y=-0.2595 x+10.1631$
$r^{2}=0.449, R=-0.670$

upper interval (red), $n=27$ $y=-0.2031 x+9.631$ significant at $\mathrm{a}=0.05( \pm 0.381)$

lower interval (blue), $\mathrm{n}=17$ $y=-0.3755 x+11.2632$ significant at $\alpha=0.05( \pm 0.482)$

variance

(ratio upper / ratio lower) not significant at $\mathrm{a}=0.05(2.53)$

both intervals, $n=30$ $y=-1.137 x+12.5358$ significant at $\mathrm{a}=0.05( \pm 0.361$ upper interval (red), $n=16$ $y=-1.12267 x+13.2234$
$r^{2}=0.397, R=-0.630$ significant at $\mathrm{a}=0.05( \pm 0.497)$ lower interval (blue), $n=14$ $y=-1.1803 x+12.6591$
$r^{2}=0.872, R=-0.934$ significant at $a=0.05( \pm 0.532)$ (b) All data (clr transformed)

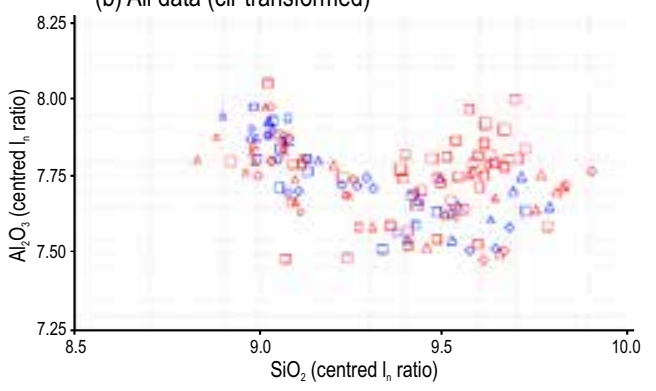

(d) 02-05 [NE] Sandstone (clr transformed)

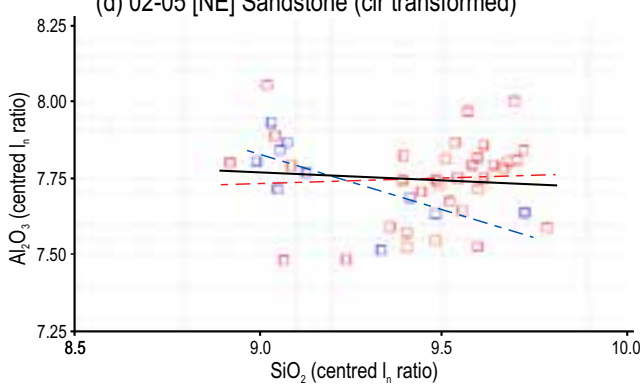

ariance

ratio upper / ratio lower) not significant at $\alpha=0.05$ (2.18)

both intervals, $n=44$

$y=-0.0531+8.2438$

not significant at $\alpha=0.05( \pm 0.304)$

upper interval (red), $n=34$

$=0.0344 x+7.4186$

$t^{2}=0.003, R=+0.053$

not significant at $\alpha=0.05( \pm 0.349)$

lower interval (blue), $n=10$

$y=-0.3636 x+11.0971$

significant at $\alpha=0.05( \pm 0.632)$

$=0.588, R=-0.767$

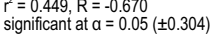

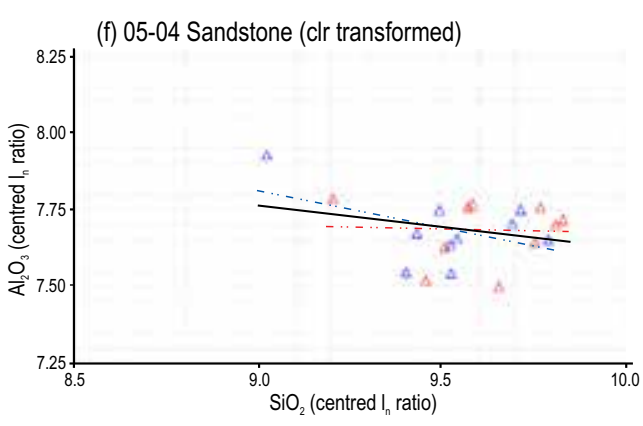

variance

(ratio upper / ratio lower) F value $=1.60$
not significant at $\alpha=0.05(3.18)$

both intervals, $n=20$ $y=-0.1358+8.9804$
$=0.072, R=-0.269$ not significant at $a=0.05( \pm 0.444)$

upper interval (red), $\mathrm{n}=10$ $y=-0.0216 x+7.887$ not significant at $a=0.05(+0.632)$

lower interval (blue), $n=10$ $y=-0.2408 x+9.975$
$z=0.215, R=-0.463$ $=0.215, R=-0.463$

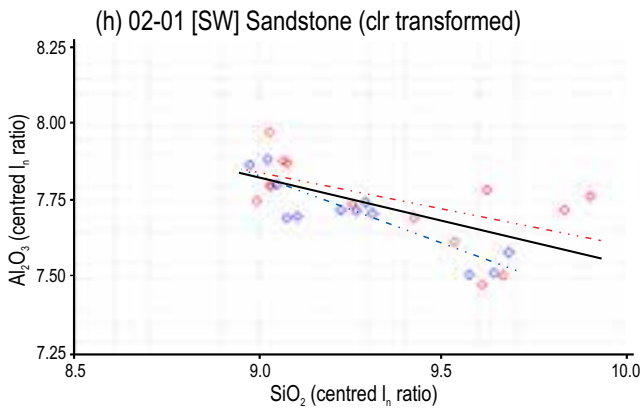

variance (ratio upper / ratio lower) not significant at $a=0.05(2.76)$

both intervals, $n=26$ $y=-0.2839+10.3735$ significant at $\alpha=0.05( \pm 0.388)$

upper interval (red), $n=14$ $y=-1.2330 x+13.2847$ $r^{2}=0.395, R=-0.629$
significant at $\alpha=0.05( \pm 0.532$

lower interval (blue) $n=12$ $y=-1.1997 x+12.7751$ ignificant at $a=0.05( \pm 0.576)$

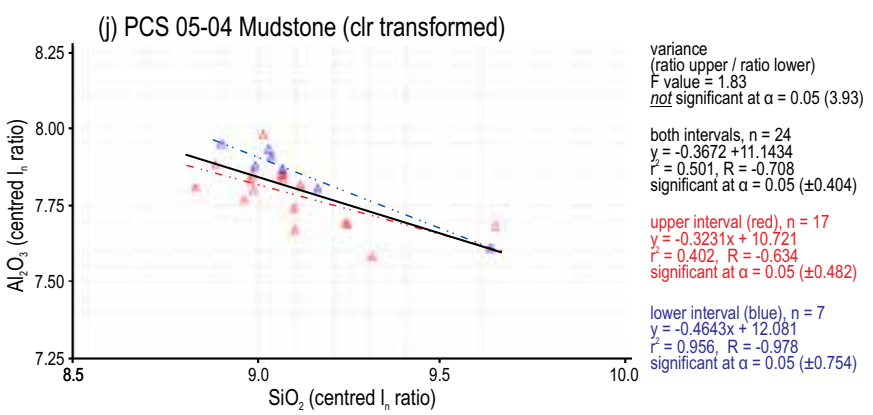

the negative gradient line of closure (Aitchison 1986), which in a plot of Si:Al runs from $0_{\mathrm{Si}}: 100_{\mathrm{Al}}$ through to $50_{\mathrm{Si}}: 50_{\mathrm{Al}}$, (pure kaolinite or similar), and down to $100_{\mathrm{Si}}: 0_{\mathrm{Al}}$ (pure silica). 
Figure 6. (previous page and below) Plots of $\mathrm{SiO}_{2}$ vs. $\mathrm{Al}_{2} \mathrm{O}_{3}$ indicating that variances are not significant (except PCS02-05) and correlations are mainly negative. Symbols area as in the legend for Figure 5. Abbreviations: $F=$ variance statistic, $n=$ number of samples analyzed, $\mathbf{r}^{2}=$ coefficient of determination, $\mathrm{R}=$ correlation coefficients, and $\alpha=$ values of significance.

(k) PCS 02-01 [SW] Mudstone (clr transformed)

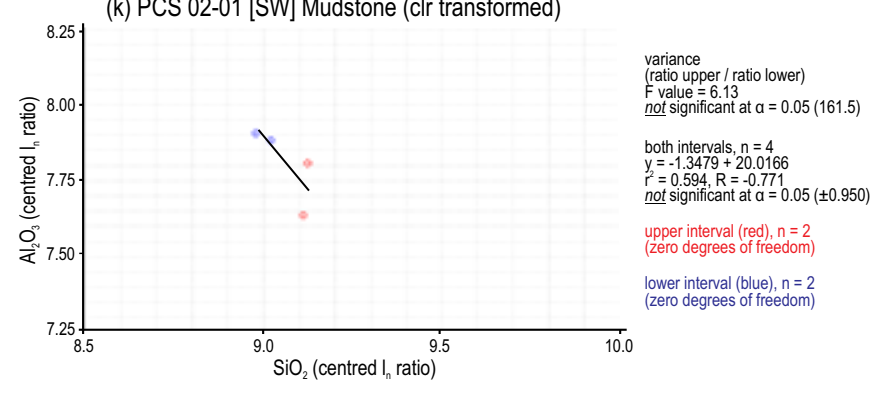

Different abundances of (alumino-) silicates in the samples trend left and below the closure line. Accordingly, even though it is likely $\mathrm{Al}$ always positively associates with $\mathrm{Si}$ (i.e., $\mathrm{Al}$ always occurs in an alumino-silicate mineral), the closure effect in a compositional dataset promotes a negative association between these two predominant elements (Davis 2002): any increase in the amount of quartz must correspond to a decrease in the amount of alumino-silicate.

As noted in the sedimentology, the upper interval contains more abundant coarser-grained lithologies. This is a potential source of bias, as quartz tends to concentrate in the coarser fraction (Korsch et al. 1993). But samples above and below the base of the grey interval exhibit a negative gradient, indicating that both high and low Si:Al ratios occur throughout the succession. Most importantly, the transformed data (Fig. 6) display more limited scatter about the regression line and significant negative correlations for the lower samples compared to the upper interval. Although the trend is not ubiquitous, it suggests less variable compositions and fewer minerals in the lower interval in all wells, regardless of grain size.

\section{$\mathrm{K}_{2} \mathrm{O}: \mathrm{Na}_{2} \mathrm{O}$}

Results: When $\mathrm{Na}_{2} \mathrm{O}$ is plotted against $\mathrm{K}_{2} \mathrm{O}$, no significant variances are noted. For all lithologies (Figs. 7c, e, g) there is a significant negative correlation to the data in the lower and upper intervals for all three boreholes, with $\mathrm{Na}$ content typically being less in the lower interval of each borehole. The same pattern is present in plots of sandstone lithologies (Figs. 7d, e, h), although correlations are significant in all cases except for the upper interval of PCS-05-04.

Interpretation: The $\mathrm{Na}_{2} \mathrm{O}$ vs. $\mathrm{K}_{2} \mathrm{O}$ scatter plot is commonly used in chemostratigraphic studies, but typically with $\mathrm{K}$ and $\mathrm{Na}$ expressed as ratios of $\mathrm{Ti}$ (whereby spurious correlations can be created if the data have not been transformed; Roll- inson 1993; Davis 2002). The plot is generally considered to reflect the proportion of albite to anorthite feldspar, and of clay minerals montmorillonite to illite (Sabaou et al. 2009). Higher Na values in the upper interval suggest a greater ratio of albite (Na-rich) in the feldspar component and probably more mafic rock (e.g., gabbro and basalt) weathered in the source. As previously noted, for the major oxides, the effect of data closure is what controls the negative trend.

\section{$\mathrm{Nb}: \mathrm{Ta}$}

Results: Raw data show the ratio of Nb:Ta is $\sim 15: 1$ (Fig. 8a). Significant variance in this ratio occurs between the upper and lower intervals in all wells (greater data spreads exist in the upper interval). However, there is only a significant positive correlation coefficient between the two elements in PCS-02-05 and for the lower interval in PCS-02-01 (for the plot of all lithologies, the three outliers of mudstone influence the significant correlation in PCS-05-04).

Interpretation: $\mathrm{Nb}$ and $\mathrm{Ta}$ are typically enriched in felsic igneous rocks (Yang et al. 2008) and these elements are known to substitute in rutile (Pearce et al. 2005; Meinhold, 2010; Tonje et al. 2013). Also, in silicic magma, the concentrations of $\mathrm{Nb}$ and $\mathrm{Ta}$ closely covary with the concentration of $\mathrm{TiO}_{2}$ and the ratio of $\mathrm{Nb} / \mathrm{Ta}$ decreases as the magmatic composition becomes less mafic and more silicic (Zhou et al. 2000). However, the variation in $\mathrm{Nb}$ should be considered when bulk geochemical data are analyzed in sandstone (Pe-Piper et al. 2008). In this study, for sandstone samples, variances are different between the upper and lower intervals indicating that the upper interval can have both more mafic and more silicic provenance components relative to the lower interval.

\section{$\mathrm{TiO}_{2}: \mathrm{Cr}$}

Results: When $\mathrm{TiO}_{2}$ is plotted against Cr (Fig. 9), the raw data indicate that $\mathrm{Cr}$ values are never greater than $\sim 1 / 60$ $\mathrm{TiO}_{2}$ values. Correlation coefficients are rarely significant (e.g., upper interval in PCS-02-01) because Cr shows little variation with respect to $\mathrm{TiO}_{2}$ However, differences in the variance of the $\mathrm{TiO}_{2}: \mathrm{Cr}$ ratio are significant in all wells, whether for all lithologies combined, or for sandstone only. $\mathrm{Cr}$ values are typically lower in the upper interval whereas $\mathrm{TiO}_{2}$ values are more variable and decrease from northeast to southwest in the upper interval.

Interpretation: The ratio of $\mathrm{Cr}: \mathrm{TiO}_{2}$ in the estimated average composition (Lentz 2003) of continental crust ( 1:53) and North American Shale Composition ( 1:63) is compatible with the present observations. However, whole-rock concentrations of $\mathrm{TiO}_{2}$ and $\mathrm{Cr}$ are controlled primarily by the abundances of the heavy minerals, e.g., chrome-spinel for $\mathrm{Cr}$ and rutile for $\mathrm{TiO}_{2}$ (Preston et al. 1998; Pearce et al. 2005; Meinhold 2010; Ratcliffe et al. 2010; Tonje et al. 2013). Also, $\mathrm{Cr}$ is more likely associated with the mafic-derived heavy 
(a) All data (raw compositional)
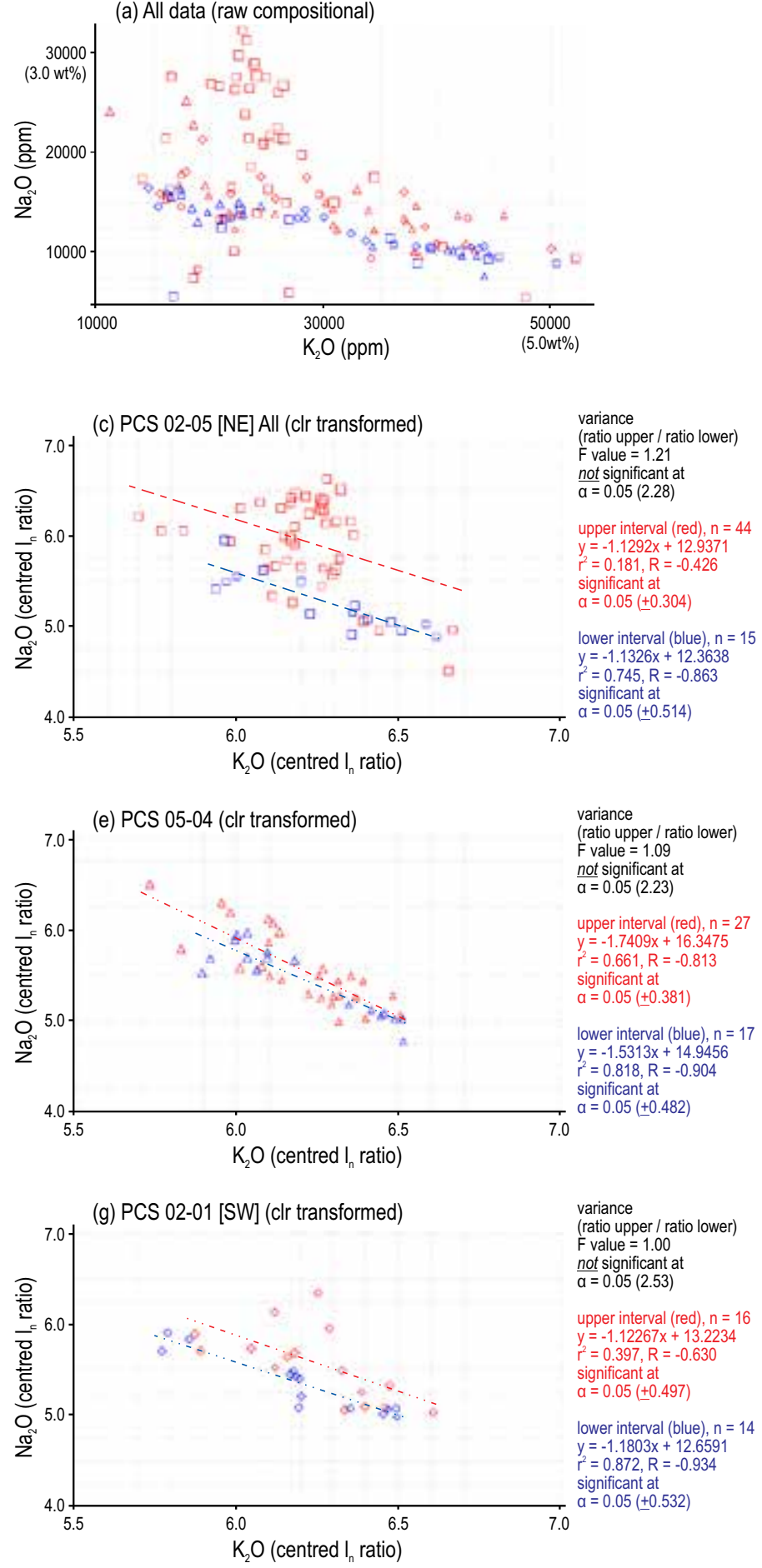

(b) All data (clr transformed)
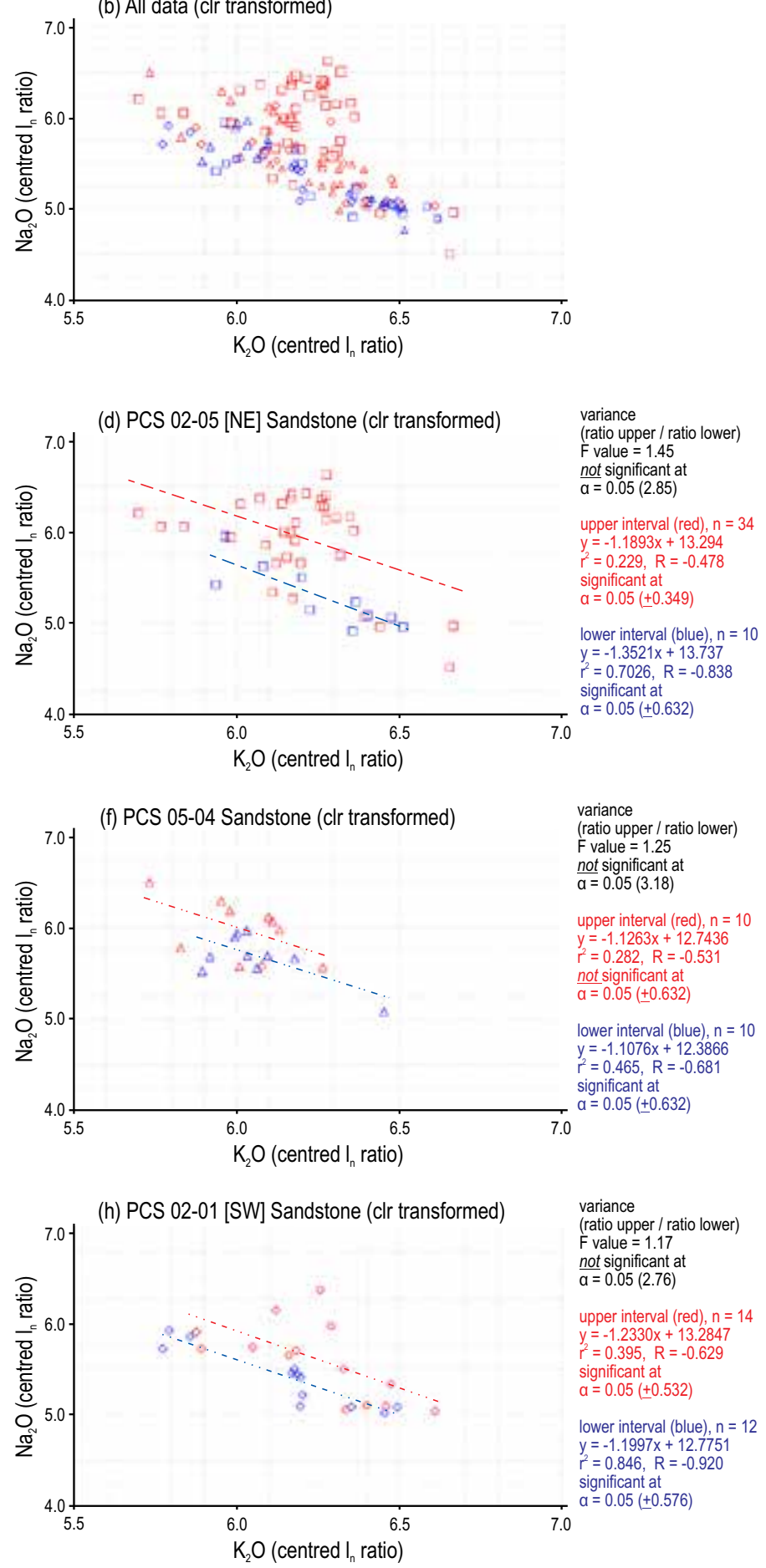

Figure 7. Plots of $\mathrm{K}_{2} \mathrm{O}$ vs. $\mathrm{Na}_{2} \mathrm{O}$ indicating that variances are not significant and negative correlations occur in all except F: sandstone in the upper interval of 05-04. Symbols are as in the legend for Figure 5. Abbreviations: $F=$ variance statistic, $\mathrm{n}=$ number of samples analyzed, $\mathbf{r}^{2}=$ coefficient of determination, $\mathrm{R}=$ correlation coefficients, and $\alpha=$ values of significance.

minerals (Garver et al. 1996; Pearce et al. 1999; Ratcliffe et al. 2010). The concentration of $\mathrm{TiO}_{2}$ is controlled by the composition of different types of magma (Ti more enriched in mafic magma) and $\mathrm{TiO}_{2}$ tends to be enriched in the residual phases during weathering (Zhou et al. 2000). The absence of significant correlations suggests that elemental con- centrations are not only a factor of the heavy mineral phase, but also of several other mineral phases, e.g., feldspars and clay minerals. Lower $\mathrm{Cr}$ values in the upper interval compared to the lower interval indicate that the upper interval had low to moderate mafic and more felsic influence in the source region. Variation in $\mathrm{TiO}_{2}$ concentration in the upper 

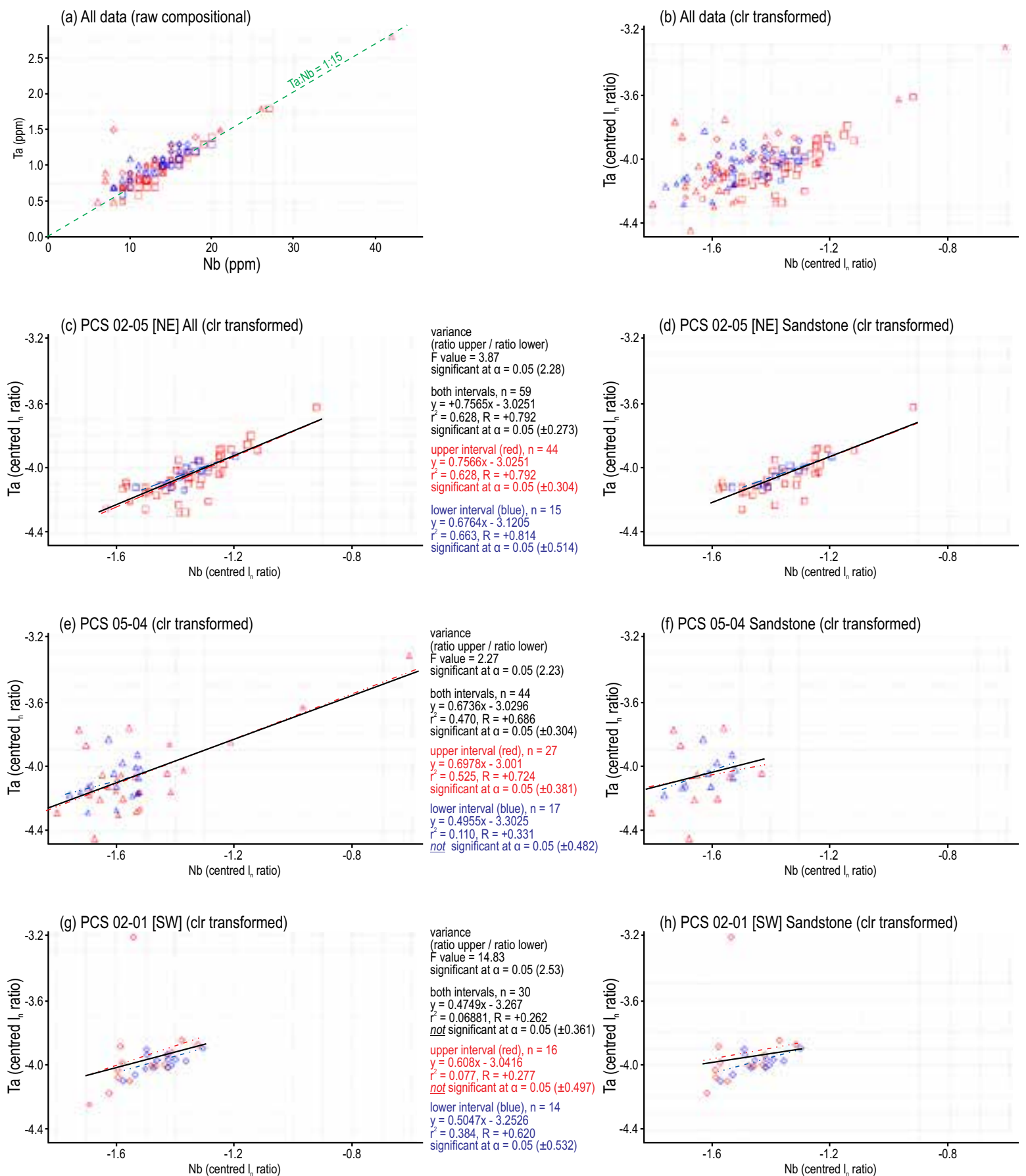

variance ratio upper / ratio lower) value $=4.10$
significant at $\alpha=0.05(2.85)$ both intervals, $n=44$ $y=+0.6946 x-3.1051$ $=0.637, R=+0.798$
significant at $\alpha=0.05( \pm 0.304)$ upper interval (red), $n=34$ $y=0.703 x-3.0976$ $=0.625, R=+0.790$
significant at $\alpha=0.05( \pm 0.349$ lower interval (blue), $\mathrm{n}=10$ $y=0.6544 x-3.1474$ $=0.836, R=+0.914$

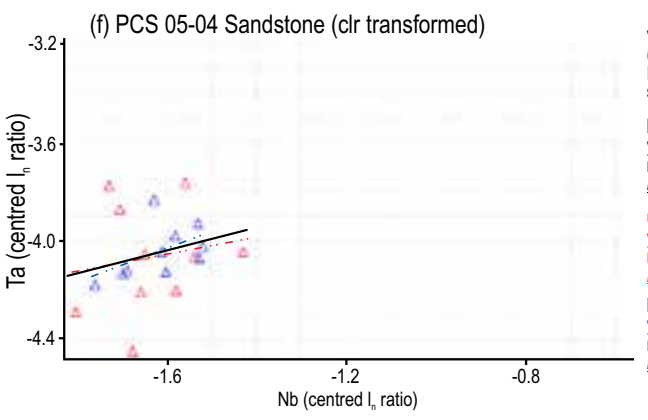

ariance (ritio upper / ratio lower) significant at $\alpha=0.05$ (3.18) both intervals, $n=20$ $y=0.4781 x-3.2815$ $y=0.4781 x-3.2815$
$r^{2}=0.068, R=+0.26$ not significant at $a=0.05( \pm 0.444)$ upper interval (red), $n=10$ $y=0.34 x-3.5165$ not significant at $\mathrm{a}=0.05( \pm 0.632)$ lower interval (blue), $\mathrm{n}=10$ $y=0.6942 x-2.9233$ $=0.2747, R=+0.524$

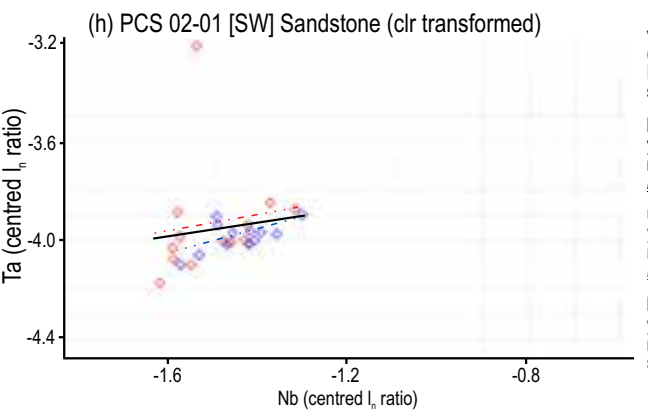

variance (ratio upper / ratio lower) F value $=14.45$
significant at $\alpha=0.05(2.76)$ both intervals, $n=26$ $\mathrm{y}=0.2684 \mathrm{x}-3.5641$
$\mathrm{r}^{2}=0.019 R=+0.139$ not significant at $\alpha=0.05( \pm 0.388)$ upper interval (red), $n=14$ $y=0.3335 x-3.4391$
$r^{2}=0.019 R=+0.137$ not significant at $\alpha=0.05( \pm 0.532)$ lower interval (blue), $n=12$ $y=0.4779 x-3.293$ significant at $a=0.05(+0.576$

Figure 8. Crossplots of $\mathrm{Nb}$ vs. Ta indicating that variances are significant and where present, correlations are positive. Symbols are as in the legend for Figure 5. Abbreviations: $F=$ variance statistic, $n=$ number of samples analyzed, $r^{2}=$ coefficient of determination, $\mathrm{R}=$ correlation coefficients, and $\alpha=$ values of significance.

interval may be due to the degree of mixture of varied source material or provenance change. Thus, the variability of $\mathrm{Cr}$ and $\mathrm{TiO}_{2}$ is related to polycyclic origin, e.g., mixing of heavy mineral phases and sediment recycling. St. Peter and Johnson (2009) previously reported the presence of a Ti-Fe placer deposit $\sim 25 \mathrm{~km}$ SE of Moncton in Hopewell Cape Formation (Mabou Group) strata, which they interpreted to reflect reworking of what would have been an uplifted, but now-buried, Ti deposit in Devonian(?) anorthosite.

\section{DISCUSSION}

The general lithofacies distribution in the studied boreholes suggests an alluvial fan to floodplain model, with the proximal fan located toward the northeast (Figs. 3, 10). Over time, the conglomerate units were able to prograde further toward the southwest. Of particular interest, however, is what we demarcate as the "bluish-grey interval", where exists a distinct combination of metre-scale bluish-grey beds 
(a) All data (raw compositional)

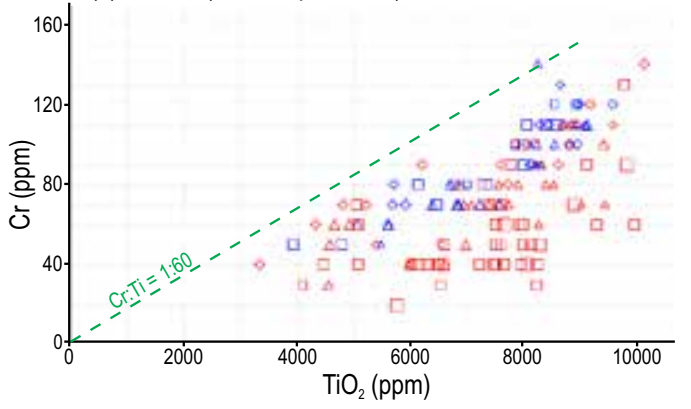

(c) PCS 02-05 [NE] All (clr transformed)

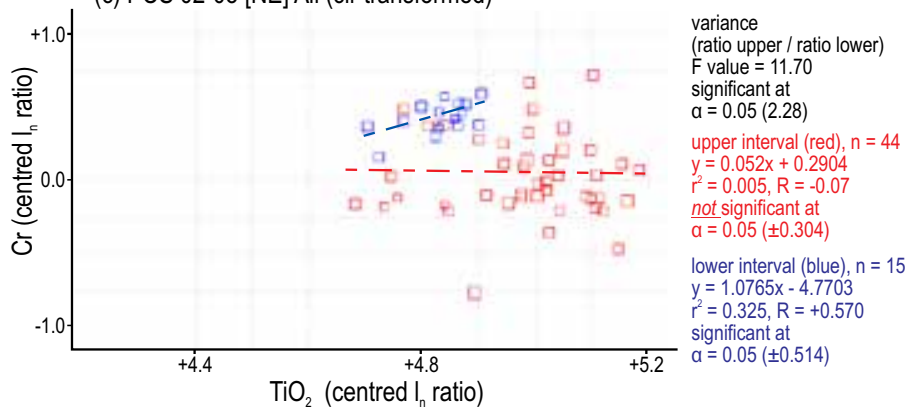

(e) PCS 05-04 (clr transformed)

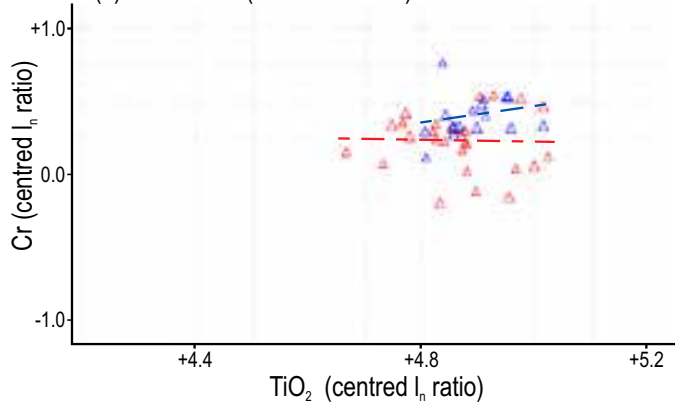

(g) PCS $02-01$ [SW] (clr transformed)
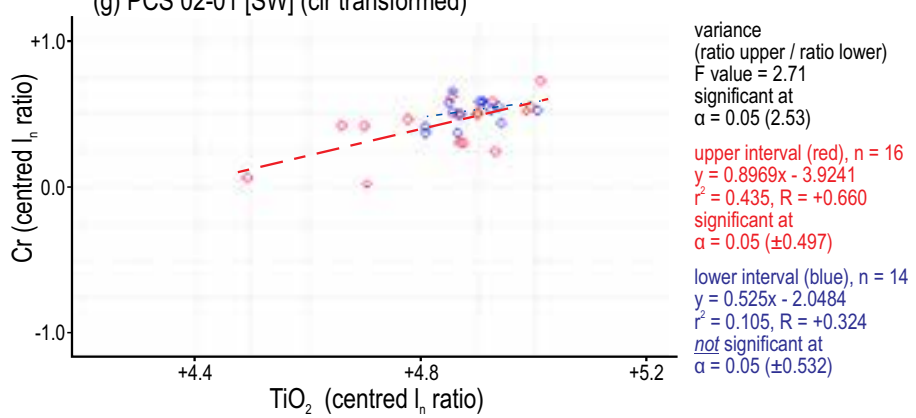

(b) All data (clr transformed)

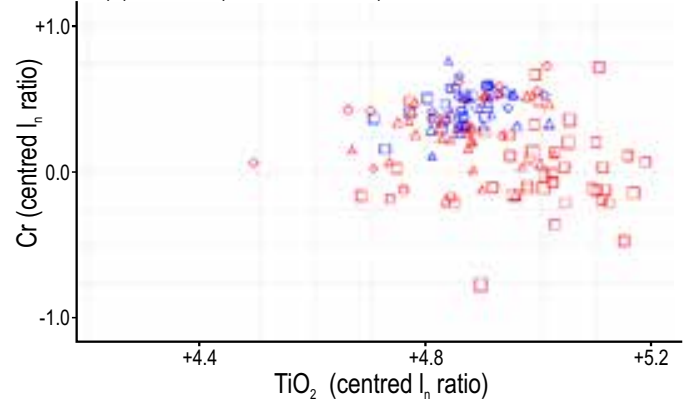

(d) PCS 02-05 [NE] Sandstone (clr transformed)

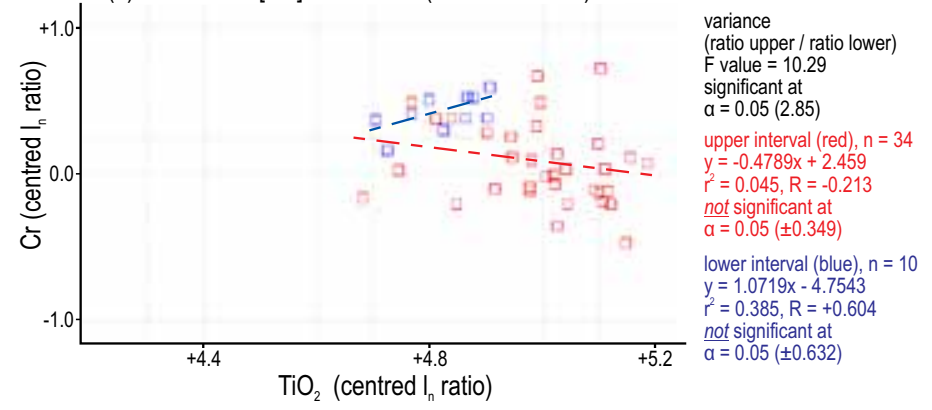

(f) PCS 05-04 Sandstone (clr transformed)

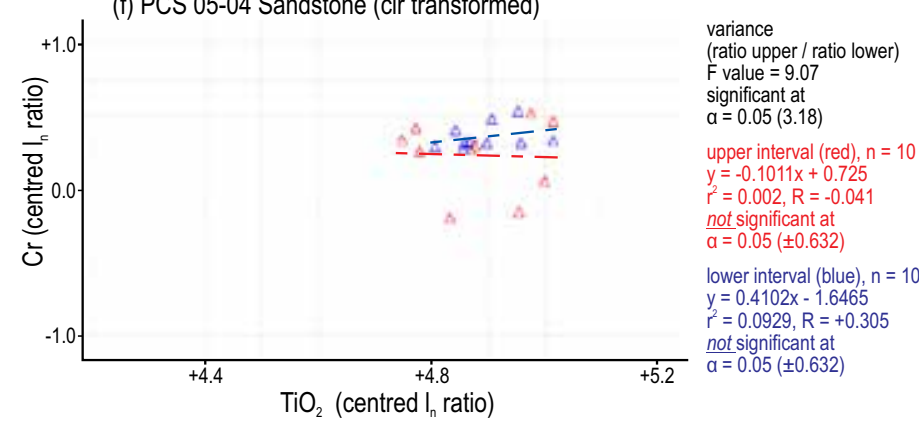

(h) PCS 02-01 [SW] Sandstone (clr transformed)

Figure 9. Crossplots of $\mathrm{TiO}_{2}$ vs. $\mathrm{Cr}$ indicating that variances are significant and correlations are mainly not significant. Symbols are as in the legend for Figure 5. Abbreviations: $F=$ variance statistic, $n=$ number of samples analyzed, $r^{2}=$ coefficient of determination, $\mathrm{R}=$ correlation coefficients, and $\alpha=$ values of significance.

of sandstone (non-red zones exist elsewhere but not at this scale), red or grey mudstone pebbles (i.e., rip-up clasts also present, but to a lesser extent, at other stratigraphic levels) and, unique to this interval, plant detritus. As previously noted, preservation of plant fragments and patchy grey colouration indicate a more prevalent reducing environment.
The presence of rip-ups suggests associated incision and reworking by channelization. This could be related to a rise in the water table (the terrestrial proxy for 'base level'), either related to relative sea- or lake level rise or simply a wetter climate resulting in more perennial discharge. The geochemical data above and below the base of the bluish-grey interval 

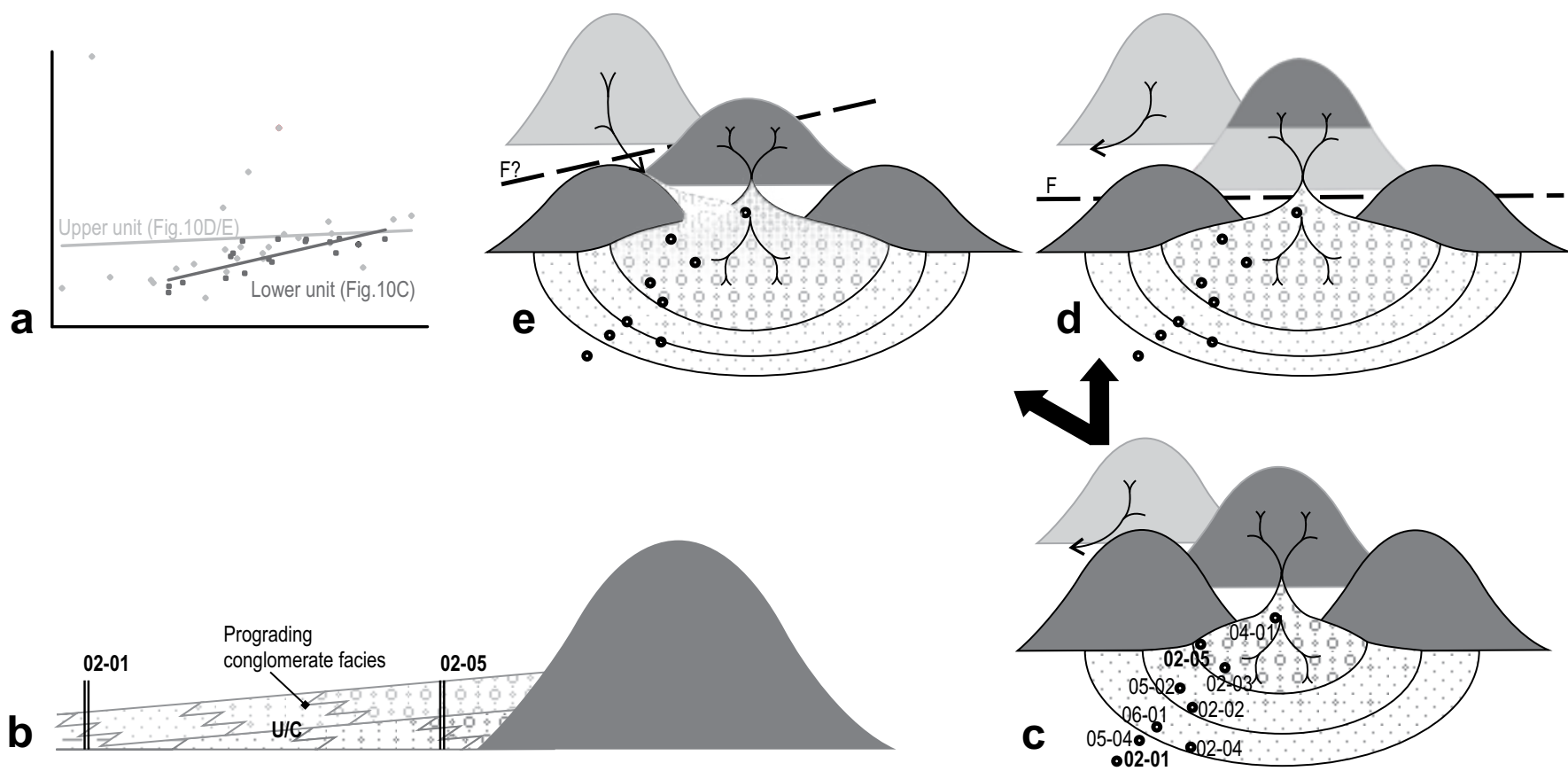

Figure 10. Schematic diagram illustrating depositional environments of the Mabou Group in the Sussex area. (a) Stylized graphical representation of data from the lower and upper units. (b) Schematic cross-section through the interpreted alluvial fan from distal (SW, borehole 02-01) to proximal (NE, borehole 02-05). (c) Early-Asbian: deposition of the lower red sandstone-siltstone interval. (d) Late-Asbian or younger: deposition of a more mineralogically varied upper red sandstone-siltstone interval due to uplift and exposure, erosion and transport of new rock types from the hinterland. (e) Late-Asbian or younger: deposition of a more mineralogically varied upper red sandstone-siltstone interval due to stream capture or expanded watershed resulting in erosion and transport of new rock types from the hinterland.

in addition indicate significant differences in the elemental compositions that likely reflect more varied provenance in the younger strata. This change could be due to gradual unroofing of additional rock types in the hinterland drainage basin.

In seismic profiles that cross the study area (Wilson and White 2005; fig 3b in Keighley 2008) a mid-Mabou angular unconformity, passing south into a (dis-) conformity can be picked, $\sim 300-400 \mathrm{~m}$ above top Windsor, to the north of the subsurface Windsor-salt diapir (Fig. 1c). The Mabou Group is everywhere poorly imaged south of the diapir in the study area, but the bluish-grey interval might sit on the same unconformity south of the diapir. If so, rip-up clasts may be the result of vertical, rather than lateral, incision due to relative base-level fall; the reducing environment was potentially the result of base-level rise during subsequent infill of the incised valley. The lack of any distinct change in the dips of beds in PCS cores from above and below the base of the grey-coloured interval favours a disconformable contact, but the limitations of assessing minor changes in bedding from core material cannot rule out an angular boundary. Elemental geochemistry indicates a more varied suite of detrital minerals above the base grey-coloured interval (i.e., above the unconformity). This is indicated in the provenance plots and the goodness of fit to regression lines of $\mathrm{Si}: \mathrm{Al}$ and $\mathrm{K}: \mathrm{Na}$, and statistically confirmed in f-tests of variance of $\mathrm{Nb}: \mathrm{Ta}$ and $\mathrm{Ti}: \mathrm{Cr}$ ratios between upper and lower intervals (Figs. 5 to 9). If tectonic uplift was involved in producing the unconformity, more varied source rocks could have been unroofed, weathered, and eroded from the hinterland. Alternatively, stream capture producing a larger hinterland exposing more varied lithologies may have resulted from uplift, or simply wetter climatic episodes, related to renewed relative base level rise following the development of the unconformity (Fig. 10).

Two different lithostratigraphic interpretations of the succession are possible. First, the grey sandstone interval, not previously recognized in outcrop in the Sussex area, may be considered equivalent to the Shepody Formation in the far southeast of New Brunswick. The lower red sandstonesiltstone interval would then be equivalent to the Middleborough Formation (syn. Maringouin Formation), and the upper red beds possibly equivalent to the Enragé Formation. In the type sections (southeastern New Brunswick), the thicknesses of the Maringouin, Shepody, and Enragé formations are $\sim 496$ to $\sim 700 \mathrm{~m}, \sim 200$ to $\sim 330 \mathrm{~m}$, and $\sim 100$ to $\sim 150 \mathrm{~m}$, respectively (St. Peter and Johnson 2009). If this interpretation is accepted, it would be the first indication in the Moncton Basin of a base-Shepody Formation disconformity, as Gussow (1953) previously identified an unconformity that he associated with the top of the formation. However, in contrast to the type sections, thicknesses of the equivalent 'formations' are quite different in the study area: $\sim 220$ to $\sim 97 \mathrm{~m}$, $\sim 75$ to $\sim 7 \mathrm{~m}$, and $\sim 300$ to $\sim 10 \mathrm{~m}$, respectively. 
Alternatively, where the Windsor Group is more extensively exposed in Nova Scotia, five transgressive-regressive cycles are delineated (Giles 2009). Interfingering red bed intervals can be more than $250 \mathrm{~m}$ thick (Ryan and Boehner 1994), and a major unconformity is identified in the Asbian. Contrastingly, in the Moncton Basin, no late-Asbian (cycle II, e.g., Lime-kiln Brook Formation) and post-Asbian (cycle III to IV) Windsor Group carbonates or evaporites are known (St. Peter and Johnson 2009): the Lime-kiln Brook Formation is present only in the far SE part of New Brunswick in the Cumberland Basin (Fig. 2; Craggs et al. 2017). If the final marine regression of the Windsor Group sea in the Moncton Basin took place before the development of the Asbian unconformity, then an alternative lithostratigraphy for the Sussex area could be that the lower red bed unit, although by definition Mabou Group (lying above the uppermost preserved limestone), may be a Windsor Group cycle I landward equivalent. The capping grey sandstone and upper red beds would be cycle II transgression and regression equivalent or younger (Fig. 10), and strata equivalent to the Shepody Formation would, if ever deposited, overlie the studied section. Red beds disconformably underlying grey and plant-bearing sandstones have also been considered Windsor Group equivalent in Québec, where they have been assigned to the Percé Group (Jutras et al. 2001; Jutras and Prichonnet 2005). Although the latter interpretation is favoured, a final decision as to the most appropriate lithostratigraphy is still considered premature, because the unconformity has still not been mapped (and confirmed) in outcrop.

\section{SUMMARY}

One of the main constraints on previous studies of the red bed succession assigned to the Mabou Group of New Brunswick has been limited data due to poor outcrop exposure. However, access to nearly $5 \mathrm{~km}$ of recent drill cores from 11 boreholes has allowed sedimentological logging of several hundred metres of a continuous red bed succession. The succession can be divided into four intervals, i.e., the lower red sandstone-siltstone interval, bluish-grey sandstone interval, upper red sandstone-siltstone interval, and red polymictic conglomerate interval. The lower three intervals are interpreted as braidplain or distal alluvial fan deposits. The conglomerate interval indicates predominately debris flow alluvial fan deposits. The bluish-grey sandstone interval is associated with relative base level change that may simply be related to climate change or possibly to the development of a disconformity at its base.

A disconformity within post-Windsor Group red beds is supported by whole-rock geochemistry of 131 samples from three of the drill holes. Elemental variations observed through analysis of major element oxides and trace elements suggest a more varied or mixed provenance above the grey-coloured sandstone interval. For example, $\mathrm{Nb}$ : Ta and Ti:Cr ratios indicate a significant difference in the variance between upper and lower intervals.

\section{ACKNOWLEDGEMENTS}

PotashCorp, and particularly project contacts Brian Roulston, Arnfinn Prugger, and Colin MacDonald, are thanked for funding the study and for permission to publish. Activation Laboratories Ltd., Ancaster, Ontario, undertook the geochemical analyses. Two anonymous reviewers provided many constructive comments that have significantly improved the manuscript, which originated as the main part of the first-named author's M.Sc. thesis at the University of New Brunswick.

\section{REFERENCES}

Abdul Aziz, H., Sanz-Rubio, E., Calvo, J.P., Hilgen, F.J., and Krijgsman, W. 2003. Palaeoenvironmental reconstruction of a Middle Miocene alluvial fan to cyclic shallow lacustrine depositional system in the Calatayud Basin (NE Spain). Sedimentology, 50, pp. 211-236. https://doi. org/10.1046/j.1365-3091.2003.00544.x

Activation Laboratories Ltd., 2014. Methods. URL < $\underline{\text { http:// }}$ www.actlabs.com/list.aspx? menu=64\&app $=226 \&-$ cat $1=549 \& \mathrm{tp}=12 \& \mathrm{lk}=$ no $>$ June 2014 .

Aitchison, J. 1986. The statistical analysis of compositional data. Chapman and Hall, London, 416 p. https://doi. org/10.1007/978-94-009-4109-0

Allen, J.P., Fielding, C.R., Rygel, M.C., and Gibling, M.R. 2013. Deconvolving signals of tectonic and climatic controls from continental basins: an example from the late Paleozoic Cumberland Basin, Atlantic Canada. Journal of Sedimentary Research, 83, pp. 847-872. https://doi. org/10.2110/jsr.2013.58

Anderle, J.P., Crosby, K.S., and Waugh, D.C.E. 1979. Potash at Salt Springs, New Brunswick. Economic Geology, 74, pp. 389-396. https://doi.org/10.2113/gsecongeo.74.2.389

Belt, E.S. 1964. Revision of Nova Scotia middle Carboniferous units. American Journal of Science, 262, pp. 653-673. https://doi.org/10.2475/ajs.262.5.653

Belt, E.S. 1965. Stratigraphy and paleogeography of Mabou Group and related middle Carboniferous facies, Nova Scotia, Canada. Geological Society of America Bulletin, 76, pp. 777-802. https://doi.org/10.1130/0016-7606(1965 $\lcm{76[777: S A P O M G] 2.0 . C O ; 2}$

Blair, T.C. and McPherson, J.G. 1992. The Trollheim alluvial fan and facies model revisited. Geological Society of America Bulletin, 104, pp. 762-769. https://doi. org/10.1130/0016-7606(1992) 104<0762:TTAFAF $>2.3$. $\underline{\mathrm{CO} ; 2}$

Blair, T.C. and McPherson, J.G. 2009. Processes and forms of alluvial fans. Geomorphology of Desert Environments, Springer, Netherlands, pp. 413-467. https://doi. org/10.1007/978-1-4020-5719-9 14

Butler, J.C. 1979. Numerical consequences of changing the units in which chemical analyses of igneous rocks are analyzed. Lithos, 12, pp. 33-39. https://doi.org/10.1016/00244937(79)90060-4

Can Mert, M., Filzmoser, P., and Hron, K. 2016. Error 
propagation in isometric log-ratio coordinates for compositional data: theoretical and practical considerations. Mathematical Geosciences, 48, pp. 941-961. https://doi. org/10.1007/s11004-016-9646-X

Chakraborti, P.P., Sarkar, A., Das, K., and Das, P. 2009. Alluvial fan to storm-dominated shelf transition in the Mesoproterozoic Singhora Group, Chattisgarh Supergroup, Central India. Precambrian Research, 170, pp. 88-106. https://doi.org/10.1016/j.precamres.2008.12.002

Chayes, F. 1960. On correlation between variables of constant sum. Journal of Geophysical Research, 65, pp. 41854193. https://doi.org/10.1029/JZ065i012p04185

Collinson, J.D. 1996. Alluvial sediments. In Sedimentary environments: processes, facies and stratigraphy. Edited by H.G. Reading. Blackwell Science, Oxford, pp. 37-82.

Craggs, S., Keighley, D., Waldron, J., and Park, A. 2017. Timing of salt tectonics affecting Pennsylvanian strata in the northern Cumberland Basin, SE New Brunswick, eastern Canada. Basin Analysis, 29, pp. 266-283.

Davis, J.C. 2002. Statistics and data analysis in geology, 3rd Edition. Wiley and Sons, New York, 638 p.

Falcon-Lang, H.J. 2004. Early Mississippian lycopsid forests in a delta-plain setting at Norton, near Sussex, New Brunswick, Canada. Journal of the Geological Society, London, 161, pp. 969-981. https://doi.org/10.1144/0016764903-168

Force, E.R. and Barr S.M. 2006. A Lower Carboniferous two-stage extensional basin along the Avalon-Meguma terrane boundary: evidence from southeastern Isle Madame, Nova Scotia. Atlantic Geology, 42, pp. 53-68. https://doi.org/10.4138/2156

Garver, J.I., Royce, P.R., and Smick, T.A. 1996. Chromium and nickel in shale of the Taconic foreland: a case study for the provenance of fine-grained sediments with an ultramafic source. Journal of Sedimentary Research, 66, pp. 100-106.

Gibling, M.R., Calder, J.H., Ryan, R., van de Poll, H.W., and Yeo, G.M. 1992. Late Carboniferous and early Permian drainage patterns in Atlantic Canada. Canadian Journal of Earth Science 29, pp. 338-352. https://doi.org/10.1139/ e92-030

Giles, P.S. 1981. Major transgressive-regressive cycles in middle to late Visean rocks of Nova Scotia. Nova Scotia Department of Mines and Energy, Paper 81-2, 27 p.

Giles, P.S. 2009. Orbital forcing and Mississippian sea level change: time series analysis of marine flooding events in the Viséan Windsor Group of eastern Canada and implications for Gondwana glaciation. Bulletin of Canadian Petroleum Geology, 57, pp. 449-471. https://doi. org/10.2113/gscpgbull.57.4.449

Gussow, W.C. 1953. Carboniferous stratigraphy and structural geology of New Brunswick, Canada. Bulletin of the American Association of Petroleum Geologists, 37, pp. 1713-1816.

Hadlari, T., Rainbird, R.H., and Donaldson, J.A. 2006. Alluvial, eolian and lacustrine sedimentology of a Paleoproterozoic half-graben, Baker Lake Basin, Nunavut, Can- ada. Sedimentary Geology, 190, pp. 47-70. https://doi. org/10.1016/j.sedgeo.2006.05.005

Hayward, N., Dehler, S.A., Grant, A.C., and Durling, P. 2014. Magnetic anomalies associated with salt tectonism, deep structure and regional tectonics in the Maritimes Basin, Atlantic Canada, 26, pp. 320-337. https://doi. org/10.1111/bre.12029

Heward, A.P. 1978. Alluvial fan sequence and megasequence models: with examples from Westphalian D-Stephanian B coalfields, Northern Spain. In Fluvial sedimentology. Edited by A.D. Miall. Canadian Society of Petroleum Geologists Memoir, 5, pp. 669-702.

Holt, N.M., García-Veigas, J., Lowenstein, T.K., Giles, P.S., and Williams-Stroud, S. 2014. The major-ion composition of Carboniferous seawater. Geochimica et Cosmochimica Acta, 134, pp. 317-334. https://doi.org/10.1016/j. gca.2014.03.009

Jutras, P. and Prichonnet, G. 2005. Record of late Mississippian tectonics in the new Percé Group (Viséan) of eastern Gaspésie, Québec. Canadian Journal of Earth Sciences, 42, pp. 815-832. https://doi.org/10.1139/e05-024

Jutras, P., Prichonnet, G., and Utting, J. 2001. Newly identified Carboniferous units (the Pointe Sawyer and Chemin-des-Pêcheurs formations) in the Gaspé Peninsula, Québec; implications regarding the evolution of the northwestern sector of the Maritimes Basin. Canadian Journal of Earth Sciences, 38, pp. 1-19. https://doi. org/10.1139/e00-073

Jutras, P., MacRae, R.A., and Utting, J. 2007. Viséan tectonostratigraphy and basin architecture beneath the Pennsylvanian New Brunswick Platform of eastern Canada. Bulletin of Canadian Petroleum Geology, 55, pp. 217236. https://doi.org/10.2113/gscpgbull.55.3.217

Jutras, P., McLeod, J., MacRae, R.A., and Utting, J. 2016. Complex interplay of faulting, glacioeustatic variations and halokinesis during deposition of Upper Viséan units over thick salt in the western Cumberland Basin of Atlantic Canada. Basin Research, 28, pp. 483-506. https://doi. org/10.1111/bre.12119

Keighley, D.G. 2008. A lacustrine shoreface succession in the Albert Formation, Moncton Basin, New Brunswick. Bulletin of Canadian Petroleum Geology, 56, pp. 235258. https://doi.org/10.2113/gscpgbull.56.4.235

Keighley, D.G. and Pickerill, R.K. 1994. The ichnogenus Beaconites and its distinction from Ancorichnus and Taenidium. Palaeontology, 37, pp. 305-337.

Keighley, D.G. and Pickerill, R.K. 2003. Ichnocoenoses from the Carboniferous of eastern Canada and their implications for the recognition of ichnofacies in nonmarine strata. Atlantic Geology, 39, pp. 1-22. https://doi. org/10.4138/1046

Khalifa, M.A., Soliman, H.E., and Wanas, H.A. 2006. The Cambrian Araba Formation in northeastern Egypt: facies and depositional environments. Journal of Asian Earth Sciences, 27, pp. 873-884. https://doi.org/10.1016/j.jseaes.2005.09.003

Korsch, R.J., Roser, B.P., and Kamprad, J.L. 1993. Geochem- 
ical, petrographic and grain-size variations within single turbidite beds. Sedimentary Geology, 83, pp. 15-35. https://doi.org/10.1016/0037-0738(93)90180-D

Köykkä, J. 2011. Precambrian alluvial fan and braidplain sedimentation patterns: example from the Mesoproterozoic Rjukan Rift Basin, southern Norway. Sedimentary Geology, 234, pp. 89-108. https://doi.org/10.1016/j.sedgeo.2010.12.004

Lentz, D.R. 2003. Geochemistry of sediments and sedimentary rocks: historical to research perspectives. In Geochemistry of sediments and sedimentary rocks: Evolutionary considerations to mineral deposit-forming environments. Edited by D.R. Lentz. Geological Association of Canada, Geotext, 4, pp. 1-6.

Logan, W.E. 1845. Appendix W: Geological Survey. In: Appendix 1 to the Fourth Volume. Journals of the Legislative

Assembly of the Province of Canada, 1844(5).

Logan, W.E. 1864. Geological map of Canada. Geological Survey of Canada, Report of Progress from its commencement to 1863. Atlas of Maps and Sections, with an Introduction and Appendix, Montreal, 1865.

Lyell, C. 1843. On the coal formation of Nova Scotia and on the age and relative position of the gypsum and accompanying marine limestones. American Journal of Arts and Sciences, 43, pp. 356-359.

Martins-Neto, M.A. 1996. Lacustrine fan-deltaic sedimentation in a Proterozoic rift basin: the Sopa-Brumadinho Tectonosequence, southeastern Brazil. Sedimentary Geology, 106, pp. 65-96. https://doi.org/10.1016/00370738(95)00152-2

McCutcheon, S.R. 1981. Stratigraphy and paleogeography of the Windsor Group in southern New Brunswick. New Brunswick Department of Natural Resources, Mineral Resources Branch, Open File Report, 81-31, 210 p.

McEwen, L.J., Owen, G., Matthews, J.A., and Hiemstra, J.F. 2011. Late Holocene development of a Norwegian alpine alluvial fan affected by proximal glacier variations, episodic distal undercutting, and colluvial activity. Geomorphology, 127, pp. 198-215. https://doi.org/10.1016/j.geomorph.2010.12.016

Meinhold, G. 2010. Rutile and its applications in earth sciences. Earth-Science Reviews, 102, pp. 1-28. https://doi. org/10.1016/j.earscirev.2010.06.001

Miall, A.D. 1977. A review of the braided river depositional environment. Earth-Science Reviews, 13, pp. 1-62. https://doi.org/10.1016/0012-8252(77)90055-1

Miall, A.D. 1978. Lithofacies types and vertical profile models in braided river deposits: a summary. In Fluvial Sedimentology. Edited by A.D. Miall. Canadian Society of Petroleum Geologist Memoir, 5, pp. 597-604.

Miall, A.D. 1996. The Geology of Fluvial Deposits. Springer-Verlag, Heidelberg, 582 p.

Murphy, J.B., Waldron, J.W., Kontak, D.J., Pe-Piper, G., and Piper, D.J. 2011. Minas Fault Zone: late Paleozoic history of an intra-continental orogenic transform fault in the Canadian Appalachians. Journal of Structural Geology, 33, pp. 312-328. https://doi.org/10.1016/j.jsg.2010.11.012
Norman, G.W.H. 1941a. Hillsborough map sheet, Albert and Westmorland counties, New Brunswick. Geological Survey of Canada, Map 647A (with marginal notes).

Norman, G.W.H. 1941b. Moncton, Westmorland and Albert Counties, New Brunswick. Geological Survey of Canada, Map 646A (with marginal notes).

North American Commission on Stratigraphic Nomenclature, 1983. North American Stratigraphic Code. American Association of Petroleum Geologists, Bulletin, 67, pp. 841-875.

Park, A.F. and St. Peter, C.J. 2009. Stratigraphy and structure of the Indian Mountain Deformed Zone, Westmorland County, southeastern New Brunswick. New Brunswick Department of Natural Resources; Minerals, Policy and Planning Division, Mineral Resource Report 2009-1, $114 \mathrm{p}$.

Park, A.F., St. Peter, C.J., and Keighley, D.G. 2007. Structural styles in Late Devonian-Early Carboniferous rocks along the southern margin of the Moncton Subbasin: Caledonia Mountain to Elgin, southeastern New Brunswick. In Geological investigations in New Brunswick for 2006. Edited by G.L. Martin. New Brunswick Department of Natural Resources; Minerals, Policy and Planning Division, Mineral Resource Report 2007-1, pp. 87-125.

Park, A.F., St. Peter, C.J., Keighley, D.G., and Wilson, P. 2010. Overstep and imbrication along a sidewall ramp and its relationship to a hydrocarbon play in Tournaisian rocks of the Moncton Basin: the Peck Creek section, Albert Mines area, southeastern New Brunswick. Bulletin of Canadian Petroleum Geology, 58, pp. 268-282. https://doi. org/10.2113/gscpgbull.58.3.268

Pearce, T.J., Besly, B.M., Wray, D.S., and Wright, D.K. 1999. Chemostratigraphy: a method to improve interwell correlation in barren sequences-a case study using onshore Duckmantian/Stephanian sequences (West Midlands, U.K.). Sedimentary Geology, 124, pp. 197-220. https:// doi.org/10.1016/S0037-0738(98)00128-6

Pearce, T.J., Wray, D.S., Ratcliffe, K.T., Wright, D.K., and Moscariello, A. 2005. Chemostratigraphy of the Upper Carboniferous Schooner Formation, southern North Sea. In Carboniferous hydrocarbon geology: the southern North Sea and surrounding onshore areas. Edited by J.D. Collinson, D.J. Evans, D.W. Holliday, and N.S. Jones. Yorkshire Geological Society, Occasional Publications Series, 7, pp. 47-164.

Pearce, T.J., Keighley, D.G., Morgan, T., and Flint, S. 2008. Chemostratigraphy in the Middle Member of the Green River Formation, Central Nine Mile Canyon, Southwest Uinta Basin, Utah. In Hydrocarbon systems and production in the Uinta Basin. Edited by M.W. Longman and C.D. Morgan. Rocky Mountain Association of Geologists and Utah Geological Association Publication, 37, pp. 121-132.

Pearson, K. 1896. Mathematical contributions to the theory of evolution. On a form of spurious correlation which may arise when indices are used in the measurement of organs. Proceedings of the Royal Society of London, 60, 
pp. 489-502. https://doi.org/10.1098/rspl.1896.0076

Pe-Piper, G., Triantafyllidis, S., and Piper, D.J. 2008. Geochemical identification of clastic sediment provenance from known sources of similar geology: the Cretaceous Scotian Basin, Canada. Journal of Sedimentary Research, 78, pp. 595-607. https://doi.org/10.2110/jsr.2008.067

Preston, J., Hartley, A., Hole, M., Buck, S., Bond, J., Mange, M., and Still, J. 1998. Integrated whole-rock trace element geochemistry and heavy mineral chemistry studies; aids to the correlation of continental red-bed reservoirs in the Beryl Field, UK North Sea. Petroleum Geoscience, 4, pp. 7-16. https://doi.org/10.1144/petgeo.4.1.7

Ratcliffe, K.T., Wright, A.M., Hallsworth, C., Morton, A., Zaitlin, B.A., Potocki, D., and Wray, D.S. 2004. An example of alternative correlation techniques in a low accommodation setting, nonmarine hydrocarbon system: the (Lower Cretaceous) Mannville Basal Quartz succession of southern Alberta. Bulletin of the American Association of Petroleum Geologists, 88, pp. 1419-1432. https://doi. org/10.1306/05100402035

Ratcliffe, K.T., Wright, A.M., Montgomery, P., Palfrey, A., Vonk, A., Vermeulen, J., and Barrett, M. 2010. Application of chemostratigraphy to the Mungaroo Formation, the Gorgon Field, offshore Northwest Australia. Australian Petroleum Production and Exploration Association Journal 2010, 50th Anniversary Issue, pp. 371-385.

Rhoads, D.C. 1967. Biogenic reworking of intertidal and subtidal sediments in Barnstable Habor and Bazzars Bay, Massachusetts. Journal of Geology, pp. 461-476. https:// doi.org/10.1086/627272

Rollinson, H.R. 1993. Using geochemical data: evaluation presentation, interpretation. Longman, England, $352 \mathrm{p}$.

Roser, B.P. and Korsch, R.J. 1988. Provenance signatures of sandstone-mudstone suites determined using discriminant function analysis of major-element data. Chemical Geology, 67, pp. 119-139. https://doi.org/10.1016/00092541(88)90010-1

Ryan, R.J. and Boehner, R.C. 1994. Geology of the Cumberland Basin, Cumberland, Colchester and Pictou Counties, Nova Scotia. Nova Scotia Department of Natural Resources, Mines and Energy Branches Memoir, 10, 222 p.

Sabaou, N., Ait-Salem, H., and Zazoun, R.S. 2009. Chemostratigraphy, tectonic setting and provenance of the Cambro-Ordovician clastic deposits of the subsurface Algerian Sahara. Journal of African Earth Sciences, 55, pp. 158-174. https://doi.org/10.1016/j.jafrearsci.2009.04.006

Sohn, Y.K., Rhee, C.W. and Kim, B.C. 1999. Debris flow and hyperconcentrated flood-flow deposits in an alluvial fan, northwestern part of the Cretaceous Yongdong Basin, central Korea. Journal of Geology, 107, pp 111-132. https://doi.org/10.1086/314334

Spalletti, L.A. and Pinol, F.C. 2005. From alluvial fan to playa: an Upper Jurassic ephemeral fluvial system, Neuquén Basin, Argentina. Gondwana Research, 8, pp. 363-383. https://doi.org/10.1016/S1342-937X(05)71141-2

St. Peter, C.J. 1993. Maritimes Basin evolution: key geologic and seismic evidence from the Moncton Subbasin of New
Brunswick. Atlantic Geology, 29, pp. 233-270. https:// doi.org/10.4138/2010

St. Peter, C.J. and Johnson, S.C. 2009. Stratigraphy and structural history of the late Paleozoic Maritimes Basin in southeastern New Brunswick, Canada. New Brunswick Department of Natural Resources; Minerals, Policy and Planning Division Memoir, 3, $348 \mathrm{p}$.

Stimson, M.R., Miller, R.F., Lucas, S.G., Park, A.F., and Hinds, S.J. 2016. Redescription of tetrapod trackways from the Mississippian Mabou Group, Lepreau Falls, New Brunswick, Canada. Atlantic Geology, 52, pp. 1-19. https://doi.org/10.4138/atlgeol.2016.001

Tonje, J.C., Ndjigui, P.D., Nyeck, B., and Bilong, P. 2013. Geochemical features of the Matomb alluvial rutile from the Neoproterozoic Pan-African belt, Southern Cameroon. Chemie der Erde - Geochemistry, 74, pp. 557-570.

Türkmen, İ., Aksoy, E., and Taşgin, C.K. 2007. Alluvial and lacustrine facies in an extensional basin: The Miocene of Malatya basin, eastern Turkey. Journal of Asian Earth Sciences, 30, pp. 181-198. https://doi.org/10.1016/j.jseaes.2006.08.006

Tuttle, M.L., Dean, W.E., and Parduhn, N.L. 1983. Inorganic geochemistry of Mahogany Zone Oil Shale in two cores from the Green River Formation. In Geochemistry and chemistry of oil shales. Edited by N. Miknis. American Chemical Society Symposium Series, 230, pp. 249-267. https://doi.org/10.1021/bk-1983-0230.ch013

Utting, J., Giles, P., and Dolby, G. 2010. Palynostratigraphy of the Mississippian and Pennsylvanian rocks, Joggins area, Nova Scotia and New Brunswick, Canada. Palynology, 34, pp. 43-89. https://doi.org/10.1080/01916121003620569

Veevers, S.J., Thomas, A.T., and Turner, P. 2007. Fan-delta sedimentation in the Silurian Coralliferous Formation of SW Wales: implications for the structure of the southern margin of the Welsh Basin. Geological Magazine, 144, pp. 319-331. https://doi.org/10.1017/S0016756806003013

Waldron, J.W.F., Rygel, M.C., Gibling, M.R., and Calder, J.H. 2013. Evaporite tectonics and the late Paleozoic stratigraphic development of the Cumberland basin, Appalachians of Atlantic Canada. Geological Society of America, Bulletin, 125, pp. 945-960. https://doi.org/10.1130/ B30718.1

Waldron, J.W.F, Barr, S.M., Park, A.F., White, C.E., and Hibbard, J.P. 2015. Late Paleozoic strike-slip faults in Maritime Canada and their role in the reconfiguration of the northern Appalachian orogen. Tectonics, 34, pp. 1-24. https://doi.org/10.1002/2015TC003882

Walker, T.R. 1967. Color of recent sediment in tropical Mexico: a contribution to the origin of red beds. Geological Society of America Bulletin, 78, pp. 917-920. https://doi. org/10.1130/0016-7606(1967)78[917:CORSIT]2.0.CO;2

Webb, T.C. 2009. New Brunswick Potash: A review of Developments and Potential Exploration Alternatives. New Brunswick Department of Natural Resources; Minerals, Policy and Planning Division, Information Circular 2008-4 (CD-ROM), 21 p.

Wilson, P. 2005. Stratigraphy, structural geology and tecton- 
ic history of the McCully area, Moncton Subbasin, southeastern New Brunswick. New Brunswick Department of Natural Resources; Minerals, Policy and Planning Division, Mineral Resource Report 2005-5, 104 p.

Wilson, P. and White, J.C. 2006. Tectonic evolution of the Moncton Basin, New Brunswick, eastern Canada: new evidence from field and sub-surface data. Bulletin of Canadian Petroleum Geology, 54, pp. 319-336. https://doi. org/10.2113/gscpgbull.54.4.319

Wilson, P., White, C.J., and Roulston, B.V. 2006. Structural geology of the Penobsquis salt structure: late Bashkirian inversion tectonics in the Moncton Basin, New Brunswick, eastern Canada. Canadian Journal of Earth Sciences, 43, pp. 405-419. https://doi.org/10.1139/e05-116

Wright, V.P. and Sandler, A. 1994. A hydrogeological model for the early diagenesis of Late Triassic alluvial sediments. Journal of the Geological Society, 151, pp. 897-900. https://doi.org/10.1144/gsigs.151.6.0897

Yang, S., Yim, W.W.-S., and Huang, G. 2008. Geochemical composition of inner shelf Quaternary sediments in the northern South China Sea with implications for provenance discrimination and paleoenvironmental reconstruction. Global and Planetary Change, 60, pp. 207-221. https://doi.org/10.1016/j.gloplacha.2007.02.005

Zhou, Y., Bohor, B.F., and Ren, Y. 2000. Trace element geochemistry of altered volcanic ash layers (tonsteins) in Late Permian coal-bearing formations of eastern Yunnan and western Guizhou Provinces, China. International Journal of Coal Geology, 44, pp. 305-324. https://doi.org/10.1016/ $\underline{\text { S0166-5162(00)00017-3 }}$

Editorial responsibility: Sandra M. Barr 
Appendix A. Whole-rock chemical analyses of samples from drill cores.

Core/ core core core core core core core core core core core core core core core core core $\begin{array}{lllllllllllllllllll}\text { Surface } & 02-01 & 02-01 & 02-01 & 02-01 & 02-01 & 02-01 & 02-01 & 02-01 & 02-01 & 02-01 & 02-01 & 02-01 & 02-01 & 02-01 & 02-01 & 02-01 & 02-01\end{array}$

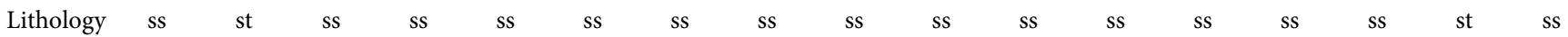

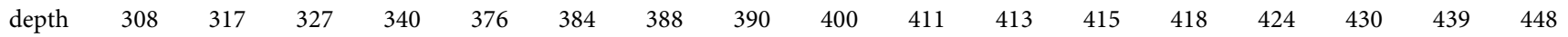
unit upper upper upper upper upper upper upper upper upper upper upper upper upper upper upper upper lower

$\mathrm{SiO}_{2} \quad 675200441000553900617400577300487500556200577500692700748700735800687600562900712200721700599400554400$

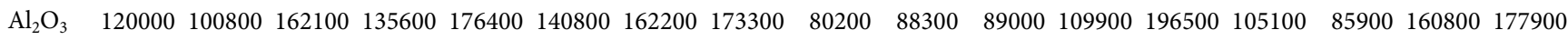
$\begin{array}{llllllllllllllllll}\mathrm{Fe}_{2} \mathrm{O}_{3}{ }^{(\mathrm{T})} & 55800 & 39200 & 74900 & 57100 & 81100 & 66000 & 80400 & 79400 & 33200 & 26800 & 32700 & 43900 & 49800 & 47300 & 39600 & 77700 & 80400\end{array}$

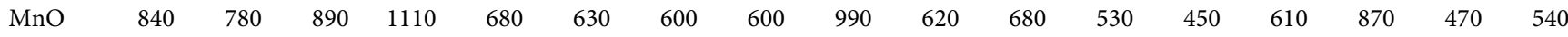

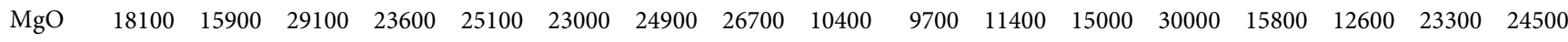
$\begin{array}{llllllllllllllllll}\mathrm{CaO} & 32200 & 129400 & 28400 & 33900 & 14300 & 73700 & 28700 & 16900 & 59900 & 38100 & 38900 & 28900 & 9800 & 30000 & 43800 & 10600 & 17200\end{array}$ $\begin{array}{lllllllllllllllllll}\mathrm{Na}_{2} \mathrm{O} & 15400 & 12300 & 16100 & 17500 & 10800 & 9500 & 10900 & 13500 & 15900 & 21300 & 18100 & 17600 & 10400 & 15900 & 14600 & 12600 & 10700\end{array}$ $\begin{array}{llllllllllllllllllll}\mathrm{K}_{2} \mathrm{O} & 25800 & 22200 & 37000 & 28500 & 42500 & 34100 & 39900 & 42600 & 15600 & 19400 & 17900 & 24500 & 50000 & 21800 & 17500 & 38900 & 44100\end{array}$ $\begin{array}{llllllllllllllllll}\mathrm{TiO}_{2} & 7550 & 5370 & 8600 & 7720 & 8930 & 7840 & 9160 & 8840 & 5200 & 3330 & 4320 & 4800 & 10120 & 7600 & 6200 & 9560 & 8690\end{array}$

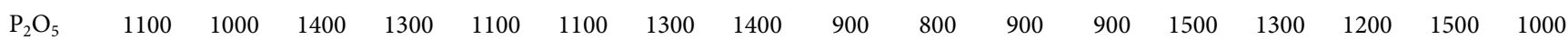
LOI $\quad \begin{array}{lllllllllllllllll}53700 & 194800 & 77900 & 64700 & 65400 & 137500 & 70300 & 63200 & 75100 & 51600 & 50600 & 53100 & 66600 & 51500 & 54300 & 54400 & 71900\end{array}$

\begin{tabular}{|c|c|c|c|c|c|c|c|c|c|c|c|c|c|c|c|c|c|}
\hline $\mathrm{Sc}$ & 12 & 10 & 18 & 14 & 18 & 16 & 18 & 18 & 6 & 5 & 6 & 9 & 22 & 11 & 8 & 17 & 19 \\
\hline $\mathrm{Be}$ & 2 & 2 & 3 & 2 & 3 & 2 & 3 & 3 & 1 & 1 & 1 & 2 & 4 & 1 & 1 & 3 & 3 \\
\hline $\mathrm{V}$ & 73 & 62 & 133 & 95 & 133 & 109 & 136 & 132 & 47 & 36 & 48 & 60 & 159 & 77 & 56 & 139 & 137 \\
\hline $\mathrm{Ba}$ & 318 & 383 & 505 & 374 & 443 & 337 & 368 & 417 & 463 & 394 & 336 & 719 & 443 & 270 & 634 & 382 & 550 \\
\hline $\mathrm{Sr}$ & 155 & 732 & 259 & 143 & 159 & 148 & 119 & 102 & 255 & 131 & 119 & 409 & 92 & 88 & 173 & 89 & 216 \\
\hline $\mathrm{Y}$ & 28 & 22 & 28 & 27 & 30 & 26 & 31 & 30 & 24 & 17 & 19 & 19 & 29 & 28 & 25 & 33 & 29 \\
\hline $\mathrm{Zr}$ & 263 & 165 & 178 & 215 & 170 & 162 & 188 & 213 & 284 & 174 & 198 & 150 & 170 & 397 & 367 & 254 & 189 \\
\hline $\mathrm{Cr}$ & 70 & 50 & 90 & 80 & 110 & 100 & 120 & 110 & 70 & 40 & 60 & 70 & 140 & 90 & 90 & 110 & 110 \\
\hline Co & 13 & 9 & 21 & 16 & 21 & 17 & 18 & 17 & 6 & 5 & 7 & 9 & 25 & 10 & 8 & 16 & 19 \\
\hline $\mathrm{Zn}$ & 90 & 90 & 140 & 120 & 150 & 110 & 120 & 130 & 60 & 50 & 60 & 80 & 120 & 70 & 70 & 110 & 140 \\
\hline $\mathrm{Ga}$ & 16 & 13 & 22 & 18 & 25 & 20 & 25 & 23 & 11 & 12 & 12 & 15 & 29 & 15 & 12 & 22 & 25 \\
\hline $\mathrm{Ge}$ & 3 & 1 & 3 & 2 & 3 & 3 & 3 & 3 & 2 & 2 & 2 & 2 & 3 & 2 & 2 & 3 & 3 \\
\hline $\mathrm{Rb}$ & 93 & 85 & 137 & 106 & 167 & 135 & 154 & 161 & 57 & 80 & 64 & 88 & 184 & 84 & 65 & 145 & 163 \\
\hline $\mathrm{Nb}$ & 13 & 9 & 14 & 12 & 16 & 14 & 16 & 15 & 9 & 8 & 8 & 9 & 18 & 13 & 10 & 16 & 15 \\
\hline Sn & 3 & 3 & 4 & 4 & 5 & 4 & 5 & 5 & 3 & 6 & 3 & 3 & 6 & 4 & 3 & 5 & 5 \\
\hline Cs & 5.3 & 4.6 & 8.8 & 6.6 & 10.3 & 8 & 8.7 & 9.4 & 2.4 & 3.6 & 2.8 & 4.3 & 10.3 & 4.1 & 3.2 & 8.3 & 9.8 \\
\hline $\mathrm{La}$ & 32.1 & 27.8 & 33.2 & 32.1 & 42.6 & 42.2 & 45 & 39.9 & 24.9 & 20.7 & 23.5 & 25.7 & 50.7 & 33.3 & 29.6 & 44.8 & 47.2 \\
\hline $\mathrm{Ce}$ & 62.4 & 55.9 & 66.2 & 66 & 85.5 & 85.8 & 91.2 & 78.8 & 52.2 & 39.6 & 46.2 & 49.2 & 95 & 67.2 & 61.3 & 88 & 92 \\
\hline $\operatorname{Pr}$ & 7.05 & 6.39 & 7.57 & 7.58 & 9.28 & 9.19 & 10.1 & 8.9 & 6.33 & 4.59 & 5.37 & 5.68 & 9.99 & 7.78 & 7.18 & 9.99 & 9.85 \\
\hline $\mathrm{Nd}$ & 27.1 & 25.2 & 29.7 & 30 & 35.6 & 33.9 & 38.3 & 33.2 & 25.5 & 18.5 & 21.2 & 22.7 & 37.3 & 30.7 & 29.3 & 37.7 & 36.3 \\
\hline $\mathrm{Sm}$ & 5.7 & 5.1 & 6.5 & 6.4 & 7.1 & 6.5 & 7.3 & 6.9 & 5.8 & 4 & 4.5 & 4.9 & 6.9 & 6.5 & 6.2 & 7.9 & 6.9 \\
\hline $\mathrm{Eu}$ & 1.25 & 1.07 & 1.41 & 1.35 & 1.59 & 1.35 & 1.57 & 1.47 & 1.14 & 0.85 & 1 & 1.08 & 1.47 & 1.31 & 1.26 & 1.65 & 1.41 \\
\hline Gd & 5.2 & 4.2 & 5.9 & 5.4 & 6.1 & 5.2 & 6.3 & 5.9 & 4.8 & 3.2 & 3.9 & 4 & 5.7 & 5.3 & 5.3 & 6.6 & 5.6 \\
\hline $\mathrm{Tb}$ & 0.8 & 0.7 & 0.9 & 0.9 & 1 & 0.8 & 1.1 & 1 & 0.7 & 0.5 & 0.6 & 0.6 & 0.9 & 0.9 & 0.8 & 1.1 & 0.9 \\
\hline Dy & 4.8 & 3.9 & 5.4 & 5 & 5.7 & 5 & 5.9 & 5.4 & 4.2 & 2.9 & 3.5 & 3.7 & 5.5 & 5 & 4.5 & 6 & 5.2 \\
\hline Ho & 1 & 0.8 & 1.1 & 1 & 1.1 & 1 & 1.2 & 1.1 & 0.8 & 0.6 & 0.7 & 0.7 & 1.1 & 1 & 0.9 & 1.2 & 1 \\
\hline Er & 2.8 & 2.2 & 3.1 & 2.9 & 3.2 & 2.8 & 3.3 & 3.2 & 2.4 & 1.7 & 2.2 & 2.2 & 3.3 & 3 & 2.6 & 3.5 & 3.1 \\
\hline $\mathrm{Tm}$ & 0.46 & 0.33 & 0.48 & 0.47 & 0.49 & 0.43 & 0.5 & 0.51 & 0.36 & 0.27 & 0.34 & 0.35 & 0.51 & 0.46 & 0.41 & 0.53 & 0.48 \\
\hline $\mathrm{Yb}$ & 3.2 & 2.2 & 3.3 & 3.1 & 3.3 & 3 & 3.3 & 3.5 & 2.4 & 1.9 & 2.2 & 2.2 & 3.5 & 3.1 & 2.7 & 3.5 & 3.3 \\
\hline $\mathrm{Lu}$ & 0.49 & 0.34 & 0.52 & 0.51 & 0.54 & 0.46 & 0.52 & 0.56 & 0.4 & 0.32 & 0.33 & 0.34 & 0.55 & 0.51 & 0.44 & 0.57 & 0.51 \\
\hline $\mathrm{Hf}$ & 6.6 & 3.9 & 4.8 & 5.8 & 4.8 & 4.5 & 5.1 & 5.7 & 7 & 4.3 & 5 & 3.9 & 4.6 & 9.8 & 9 & 6.7 & 5 \\
\hline $\mathrm{Ta}$ & 1 & 0.7 & 1.1 & 1 & 1.3 & 1.1 & 1.2 & 1.2 & 0.9 & 1.5 & 0.7 & 0.7 & 1.4 & 1.1 & 0.9 & 1.3 & 1.3 \\
\hline $\mathrm{Tl}$ & 0.6 & 0.5 & 0.9 & 0.7 & 0.9 & 0.7 & 0.8 & 0.9 & 0.3 & 0.4 & 0.4 & 0.6 & 1.1 & 0.4 & 0.4 & 0.8 & 1 \\
\hline $\mathrm{Pb}$ & 22 & 26 & 38 & 28 & 27 & 17 & 17 & 28 & 9 & 9 & 8 & 12 & 15 & 8 & 9 & 24 & 30 \\
\hline Th & 9.6 & 7.3 & 10.9 & 10.1 & 13 & 11 & 12.3 & 13.1 & 7.8 & 5.9 & 6.7 & 7.5 & 14.5 & 10.1 & 8.8 & 13.1 & 13.2 \\
\hline $\mathrm{U}$ & 2.4 & 2.1 & 3.4 & 3.1 & 3.3 & 2.7 & 4 & 3.4 & 1.9 & 1.4 & 1.6 & 1.8 & 4.1 & 2.6 & 2.2 & 3.3 & 3.1 \\
\hline
\end{tabular}


Appendix A. Continued.

\begin{tabular}{|c|c|c|c|c|c|c|c|c|c|c|c|c|c|c|c|c|c|}
\hline Core/ & core & core & core & core & core & core & core & core & core & core & core & core & core & core & core & core & core \\
\hline Surface & $02-01$ & $02-01$ & $02-01$ & $02-01$ & $02-01$ & $02-01$ & $02-01$ & $02-01$ & $02-01$ & $02-01$ & $02-01$ & $02-01$ & $02-01$ & 05-04 & 05-04 & 05-04 & 05-04 \\
\hline Lithology & ss & ss & ss & st & st & ss & ss & ss & ss & ss & ss & ss & ss & st & st & st & st \\
\hline depth & 455 & 457 & 468 & 478 & 480 & 494 & 514 & 515 & 524 & 529 & 530 & 542 & 588 & 287 & 306 & 342 & 352 \\
\hline unit & lower & lower & lower & lower & lower & lower & lower & lower & lower & lower & lower & lower & lower & upper & upper & upper & upper \\
\hline $\mathrm{SiO}_{2}$ & 714600 & 715600 & 543300 & 533000 & 549900 & 641800 & 590800 & 565800 & 619500 & 694700 & 639700 & 602100 & 618900 & 611000 & 641000 & 635400 & 687700 \\
\hline $\mathrm{Al}_{2} \mathrm{O}_{3}$ & 85400 & 88100 & 180100 & 182200 & 176200 & 129800 & 145500 & 163400 & 138300 & 88500 & 136800 & 151700 & 132100 & 157800 & 135500 & 113400 & 96900 \\
\hline $\mathrm{Fe}_{2} \mathrm{O}_{3}{ }^{(\mathrm{T})}$ & 34800 & 34300 & 84700 & 91000 & 83600 & 58700 & 64000 & 72100 & 63000 & 36000 & 58400 & 65200 & 59900 & 66900 & 66100 & 51300 & 35800 \\
\hline $\mathrm{MnO}$ & 990 & 880 & 600 & 640 & 620 & 860 & 830 & 670 & 740 & 1490 & 680 & 870 & 800 & 1130 & 780 & 870 & 1160 \\
\hline $\mathrm{MgO}$ & 12000 & 12800 & 27500 & 28300 & 27000 & 20800 & 24100 & 27700 & 22400 & 14400 & 23100 & 25000 & 25900 & 27300 & 19700 & 16300 & 13500 \\
\hline $\mathrm{CaO}$ & 53300 & 43500 & 19300 & 23900 & 20700 & 35300 & 40300 & 35100 & 33400 & 62800 & 28800 & 35100 & 33600 & 5700 & 15200 & 53500 & 51100 \\
\hline $\mathrm{Na}_{2} \mathrm{O}$ & 16000 & 16500 & 10400 & 9800 & 10600 & 13500 & 12000 & 10700 & 13600 & 14600 & 14300 & 11200 & 13400 & 10100 & 12300 & 13900 & 15700 \\
\hline $\mathrm{K}_{2} \mathrm{O}$ & 16200 & 14600 & 43600 & 44500 & 42900 & 27700 & 32400 & 38100 & 30000 & 15500 & 28400 & 33700 & 28400 & 37900 & 31200 & 25700 & 19900 \\
\hline $\mathrm{TiO}_{2}$ & 5670 & 5690 & 9570 & 8630 & 8990 & 8120 & 8430 & 8940 & 8270 & 5900 & 8800 & 8930 & 8040 & 9010 & 9420 & 8260 & 5960 \\
\hline $\mathrm{P}_{2} \mathrm{O}_{5}$ & 1000 & 900 & 1300 & 1300 & 1200 & 1300 & 1300 & 1500 & 1400 & 1000 & 1300 & 1300 & 1100 & 1400 & 1400 & 1100 & 800 \\
\hline LOI & 67900 & 58600 & 70000 & 74600 & 68800 & 63100 & 72500 & 74900 & 64500 & 72400 & 59400 & 71800 & 68600 & 54300 & 52100 & 64200 & 55200 \\
\hline $\mathrm{Sc}$ & 8 & 8 & 20 & 20 & 20 & 14 & 16 & 18 & 15 & 9 & 14 & 16 & 14 & 16 & 14 & 11 & 9 \\
\hline $\mathrm{Be}$ & 1 & 1 & 3 & 3 & 3 & 2 & 2 & 3 & 2 & 1 & 2 & 2 & 2 & 4 & 3 & 2 & 1 \\
\hline $\mathrm{V}$ & 57 & 61 & 153 & 145 & 149 & 96 & 114 & 135 & 107 & 61 & 104 & 114 & 104 & 109 & 96 & 87 & 73 \\
\hline $\mathrm{Ba}$ & 180 & 160 & 469 & 464 & 456 & 344 & 497 & 443 & 350 & 380 & 353 & 447 & 399 & 427 & 382 & 316 & 328 \\
\hline $\mathrm{Sr}$ & 198 & 127 & 146 & 168 & 144 & 121 & 205 & 175 & 137 & 190 & 129 & 176 & 169 & 105 & 111 & 108 & 110 \\
\hline $\mathrm{Y}$ & 25 & 23 & 30 & 29 & 29 & 29 & 29 & 29 & 28 & 26 & 29 & 31 & 28 & 40 & 33 & 33 & 24 \\
\hline $\mathrm{Zr}$ & 412 & 325 & 169 & 159 & 165 & 228 & 208 & 180 & 233 & 253 & 238 & 271 & 221 & 318 & 390 & 387 & 258 \\
\hline $\mathrm{Cr}$ & 70 & 80 & 120 & 130 & 120 & 90 & 110 & 120 & 110 & 70 & 100 & 100 & 100 & 70 & 70 & 60 & 40 \\
\hline Co & 9 & 10 & 22 & 21 & 21 & 16 & 17 & 19 & 16 & 10 & 16 & 17 & 16 & 18 & 15 & 12 & 9 \\
\hline $\mathrm{Zn}$ & 60 & 60 & 130 & 140 & 120 & 100 & 100 & 120 & 110 & 70 & 100 & 550 & 100 & 120 & 100 & 90 & 60 \\
\hline $\mathrm{Ga}$ & 12 & 13 & 26 & 25 & 25 & 18 & 20 & 23 & 19 & 12 & 18 & 21 & 19 & 21 & 18 & 14 & 11 \\
\hline $\mathrm{Ge}$ & 2 & 2 & 3 & 3 & 3 & 2 & 3 & 3 & 3 & 2 & 2 & 2 & 2 & 3 & 3 & 3 & 2 \\
\hline $\mathrm{Rb}$ & 58 & 58 & 168 & 168 & 160 & 110 & 124 & 144 & 115 & 60 & 110 & 126 & 109 & 147 & 115 & 95 & 72 \\
\hline $\mathrm{Nb}$ & 10 & 10 & 17 & 15 & 16 & 14 & 16 & 16 & 14 & 10 & 16 & 16 & 15 & 26 & 15 & 14 & 9 \\
\hline Sn & 3 & 4 & 5 & 5 & 5 & 4 & 4 & 5 & 5 & 3 & 4 & 7 & 4 & 5 & 3 & 2 & 2 \\
\hline Cs & 3 & 3 & 9.8 & 10.1 & 9.5 & 6.7 & 7.5 & 8.7 & 6.8 & 3.3 & 6.8 & 7.6 & 6.3 & 8.4 & 6.3 & 4.8 & 3.1 \\
\hline $\mathrm{La}$ & 28.2 & 27.8 & 45.7 & 42.3 & 46.7 & 34.5 & 50.8 & 40.3 & 39.5 & 27.7 & 35.5 & 45.1 & 34.8 & 42.6 & 42.9 & 34.3 & 25.6 \\
\hline $\mathrm{Ce}$ & 58.3 & 56.5 & 89.5 & 83.6 & 93.3 & 69.7 & 97.4 & 79.9 & 79.6 & 57.1 & 70.3 & 90.7 & 70 & 94.4 & 85.2 & 74 & 55.3 \\
\hline $\operatorname{Pr}$ & 6.77 & 6.47 & 9.84 & 9.3 & 10.2 & 7.81 & 10.5 & 8.94 & 8.82 & 6.66 & 8.02 & 9.93 & 7.73 & 9.36 & 9.01 & 8.56 & 6.77 \\
\hline $\mathrm{Nd}$ & 27.4 & 25.4 & 38.1 & 36.3 & 37.4 & 30.7 & 39.3 & 34.7 & 33.2 & 27.6 & 30.8 & 37.1 & 29.5 & 35.4 & 32.8 & 33.4 & 26.4 \\
\hline $\mathrm{Sm}$ & 6.1 & 5.5 & 7.4 & 7.3 & 7.2 & 6.3 & 7.4 & 7.1 & 6.4 & 6.5 & 6.3 & 7 & 6.2 & 7 & 6.8 & 6.8 & 5.6 \\
\hline $\mathrm{Eu}$ & 1.09 & 1.08 & 1.64 & 1.5 & 1.5 & 1.36 & 1.62 & 1.51 & 1.3 & 1.36 & 1.28 & 1.4 & 1.3 & 1.4 & 1.26 & 1.41 & 1.15 \\
\hline Gd & 5 & 4.5 & 6.3 & 5.7 & 5.9 & 5.4 & 6.3 & 5.9 & 5.3 & 5.5 & 5.2 & 5.6 & 5.5 & 6.9 & 6 & 6.6 & 4.9 \\
\hline $\mathrm{Tb}$ & 0.8 & 0.8 & 1 & 0.9 & 0.9 & 0.9 & 1 & 0.9 & 0.9 & 0.9 & 0.9 & 1 & 0.9 & 1.2 & 1 & 1 & 0.8 \\
\hline Dy & 4.5 & 4.4 & 5.6 & 5.3 & 5.6 & 5 & 5.6 & 5.4 & 5.2 & 4.6 & 5.2 & 5.5 & 5 & 7.1 & 5.8 & 5.9 & 4.7 \\
\hline Ho & 0.9 & 0.9 & 1.1 & 1 & 1.1 & 1 & 1.1 & 1.1 & 1.1 & 0.9 & 1.1 & 1.1 & 1 & 1.5 & 1.2 & 1.2 & 0.9 \\
\hline Er & 2.6 & 2.5 & 3.2 & 3 & 3.2 & 2.8 & 3.1 & 3.1 & 3 & 2.5 & 3.1 & 3.1 & 2.9 & 4 & 3.5 & 3.4 & 2.4 \\
\hline $\mathrm{Tm}$ & 0.4 & 0.37 & 0.5 & 0.47 & 0.48 & 0.44 & 0.47 & 0.48 & 0.45 & 0.39 & 0.48 & 0.49 & 0.45 & 0.63 & 0.55 & 0.51 & 0.38 \\
\hline $\mathrm{Yb}$ & 2.7 & 2.5 & 3.4 & 3.2 & 3.1 & 3 & 3.2 & 3.2 & 3.1 & 2.7 & 3.3 & 3.3 & 3 & 4.1 & 3.8 & 3.4 & 2.6 \\
\hline $\mathrm{Lu}$ & 0.43 & 0.42 & 0.55 & 0.52 & 0.5 & 0.48 & 0.51 & 0.51 & 0.5 & 0.43 & 0.51 & 0.55 & 0.47 & 0.65 & 0.61 & 0.51 & 0.39 \\
\hline $\mathrm{Hf}$ & 10.1 & 8.2 & 4.6 & 4.4 & 4.6 & 5.9 & 5.5 & 4.8 & 5.9 & 6.3 & 6.4 & 6.9 & 5.9 & 7.5 & 8.5 & 8.6 & 5.7 \\
\hline $\mathrm{Ta}$ & 0.8 & 0.9 & 1.3 & 1.2 & 1.3 & 1.1 & 1.2 & 1.2 & 1.1 & 0.8 & 1.2 & 1.3 & 1.1 & 1.8 & 1.3 & 0.9 & 0.7 \\
\hline $\mathrm{Tl}$ & 0.3 & 0.3 & 0.9 & 0.9 & 0.8 & 0.7 & 0.7 & 0.8 & 0.7 & 0.4 & 0.6 & 0.7 & 0.6 & 0.9 & 0.6 & 0.5 & 0.4 \\
\hline $\mathrm{Pb}$ & 10 & 8 & 33 & 30 & 23 & 24 & 30 & 28 & 24 & 12 & 20 & 53 & 20 & 30 & 31 & 25 & 14 \\
\hline Th & 8.9 & 8.1 & 14 & 12.7 & 13 & 10.1 & 12.6 & 12.2 & 11.2 & 8.1 & 11.1 & 12.3 & 10.7 & 12.7 & 12 & 10.1 & 7.4 \\
\hline $\mathrm{U}$ & 2.3 & 2.3 & 3.3 & 3.2 & 3.2 & 2.7 & 3.2 & 3.6 & 2.9 & 2.2 & 3.1 & 3.1 & 3 & 3 & 3 & 3.4 & 1.9 \\
\hline
\end{tabular}


Appendix A. Continued.

Core/ core core core core core core core core core core core core core core core core core $\begin{array}{lllllllllllllllllll}\text { Surface } & 05-04 & 05-04 & 05-04 & 05-04 & 05-04 & 05-04 & 05-04 & 05-04 & 05-04 & 05-04 & 05-04 & 05-04 & 05-04 & 05-04 & 05-04 & 05-04 & 05-04\end{array}$ $\begin{array}{llllllllllllllllll}\text { Lithology } & \text { st } & \text { ss } & \text { ss } & \text { ss } & \text { st } & \text { ss } & \text { st } & \text { st } & \text { st } & \text { st } & \text { st } & \text { st } & \text { st } & \text { st } & \text { st } & \text { st } & \text { st }\end{array}$

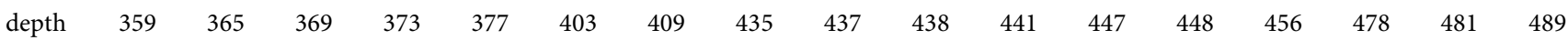
unit upper upper upper upper upper upper upper upper upper upper upper upper upper upper upper upper upper

$\mathrm{SiO}_{2} \quad 561500666800682500619800607000634700554400505600532500527900482400536200505000581400550400509100529700$

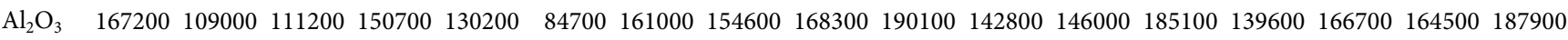
$\begin{array}{llllllllllllllllllll}\mathrm{Fe}_{2} \mathrm{O}_{3}{ }^{(\mathrm{T})} & 77100 & 35500 & 40800 & 68200 & 58300 & 21800 & 73400 & 68000 & 69900 & 78500 & 60400 & 61200 & 80400 & 59700 & 75600 & 75000 & 79200\end{array}$

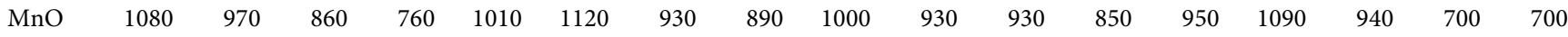
$\begin{array}{llllllllllllllllll}\mathrm{MgO} & 27200 & 14100 & 15900 & 24700 & 21100 & 8200 & 28400 & 25400 & 27700 & 31500 & 24600 & 28000 & 41800 & 27600 & 31100 & 29300 & 26500\end{array}$ $\begin{array}{llllllllllllllllllll}\mathrm{CaO} & 22300 & 56100 & 45000 & 13100 & 50900 & 96800 & 27800 & 53100 & 41000 & 19100 & 77800 & 55400 & 21500 & 43700 & 26100 & 38500 & 25100\end{array}$ $\begin{array}{lllllllllllllllllll}\mathrm{Na}_{2} \mathrm{O} & 12400 & 25200 & 22800 & 16300 & 14400 & 24100 & 14700 & 12300 & 13100 & 13700 & 12800 & 14200 & 13700 & 15000 & 13400 & 9700 & 10200\end{array}$ $\begin{array}{llllllllllllllllllll}\mathrm{K}_{2} \mathrm{O} & 37700 & 17900 & 18600 & 32900 & 30800 & 11200 & 38100 & 34400 & 37200 & 41800 & 30800 & 33900 & 45800 & 30200 & 37000 & 38400 & 43200\end{array}$ $\begin{array}{llllllllllllllllll}\mathrm{TiO}_{2} & 8520 & 6590 & 6970 & 9410 & 7730 & 4550 & 8380 & 7880 & 8310 & 8210 & 7070 & 7540 & 8220 & 7380 & 8800 & 8810 & 8680\end{array}$

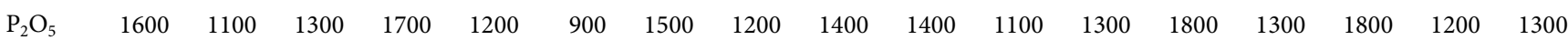
LOI $\quad \begin{array}{llllllllllllllllllll}65600 & 55500 & 58700 & 55300 & 74300 & 101200 & 75000 & 120300 & 92600 & 82800 & 148100 & 102600 & 81800 & 87100 & 75400 & 107800 & 82200\end{array}$

\begin{tabular}{|c|c|c|c|c|c|c|c|c|c|c|c|c|c|c|c|c|c|}
\hline $\mathrm{Sc}$ & 17 & 10 & 10 & 16 & 13 & 6 & 17 & 16 & 18 & 19 & 15 & 15 & 22 & 14 & 18 & 18 & 19 \\
\hline $\mathrm{Be}$ & 3 & 1 & 1 & 3 & 2 & 1 & 3 & 3 & 3 & 4 & 2 & 2 & 4 & 2 & 3 & 3 & 3 \\
\hline V & 110 & 73 & 77 & 121 & 85 & 48 & 122 & 117 & 129 & 144 & 106 & 133 & 155 & 105 & 137 & 163 & 143 \\
\hline $\mathrm{Ba}$ & 429 & 553 & 573 & 384 & 440 & 213 & 425 & 504 & 518 & 518 & 431 & 453 & 533 & 563 & 548 & 468 & 455 \\
\hline Sr & 103 & 216 & 215 & 91 & 267 & 609 & 118 & 252 & 321 & 199 & 321 & 276 & 190 & 640 & 275 & 173 & 189 \\
\hline $\mathrm{Y}$ & 28 & 26 & 25 & 30 & 29 & 22 & 31 & 28 & 29 & 40 & 25 & 28 & 31 & 27 & 35 & 28 & 27 \\
\hline $\mathrm{Zr}$ & 175 & 261 & 333 & 238 & 286 & 181 & 188 & 174 & 198 & 309 & 164 & 217 & 139 & 192 & 218 & 145 & 144 \\
\hline $\mathrm{Cr}$ & 80 & 40 & 50 & 100 & 70 & 30 & 80 & 80 & 90 & 90 & 70 & 80 & 100 & 70 & 100 & 110 & 110 \\
\hline Co & 22 & 9 & 9 & 17 & 14 & 4 & 19 & 17 & 19 & 22 & 15 & 16 & 25 & 21 & 20 & 20 & 21 \\
\hline $\mathrm{Zn}$ & 150 & 60 & 60 & 120 & 90 & 27 & 110 & 100 & 120 & 130 & 100 & 100 & 140 & 760 & 120 & 130 & 110 \\
\hline $\mathrm{Ga}$ & 22 & 12 & 12 & 20 & 16 & 8 & 21 & 20 & 21 & 27 & 17 & 18 & 26 & 17 & 21 & 23 & 24 \\
\hline $\mathrm{Ge}$ & 3 & 2 & 2 & 3 & 2 & 2 & 3 & 3 & 3 & 3 & 2 & 2 & 3 & 2 & 3 & 3 & 3 \\
\hline $\mathrm{Rb}$ & 155 & 61 & 63 & 130 & 111 & 38 & 144 & 129 & 143 & 161 & 110 & 123 & 175 & 112 & 142 & 158 & 164 \\
\hline $\mathrm{Nb}$ & 14 & 10 & 9 & 15 & 12 & 6 & 14 & 13 & 17 & 42 & 11 & 12 & 13 & 12 & 21 & 14 & 14 \\
\hline Sn & 4 & 2 & 2 & 4 & 3 & 1 & 4 & 3 & 4 & 6 & 3 & 3 & 4 & 5 & 4 & 4 & 4 \\
\hline Cs & 8.9 & 2.3 & 2.8 & 7.6 & 5.9 & 1.5 & 8.7 & 8.2 & 9.2 & 10.1 & 7.2 & 7.4 & 11.3 & 6.5 & 8.9 & 9.1 & 9.5 \\
\hline $\mathrm{La}$ & 37.3 & 24.2 & 26.2 & 34.4 & 37.1 & 19.7 & 37.4 & 36.7 & 38.3 & 38.6 & 28.7 & 31.8 & 34.4 & 26.6 & 40.2 & 35.5 & 40.8 \\
\hline $\mathrm{Ce}$ & 79.4 & 51.4 & 53.1 & 72.4 & 77.4 & 45.8 & 79.6 & 83.9 & 82.6 & 89.2 & 62 & 67.4 & 80 & 59.3 & 84.8 & 74.6 & 83.9 \\
\hline $\operatorname{Pr}$ & 8.92 & 6.32 & 6.27 & 8.06 & 8.35 & 5.46 & 8.6 & 9.02 & 9.07 & 9.04 & 6.78 & 7.17 & 8.91 & 6.7 & 9.23 & 8.24 & 9.16 \\
\hline $\mathrm{Nd}$ & 34.2 & 24.7 & 24.7 & 31.1 & 31.7 & 23.1 & 33.8 & 35.1 & 35.8 & 36 & 26.5 & 27 & 36.5 & 27.7 & 35.5 & 31.3 & 34.6 \\
\hline Sm & 7 & 5.3 & 4.9 & 6.3 & 6.4 & 4.6 & 7 & 6.3 & 6.9 & 8.2 & 5.1 & 5.6 & 7.2 & 5.7 & 7 & 6.4 & 6.8 \\
\hline $\mathrm{Eu}$ & 1.5 & 1.12 & 1.02 & 1.37 & 1.28 & 1.13 & 1.36 & 1.38 & 1.37 & 1.57 & 1.12 & 1.21 & 1.59 & 1.25 & 1.47 & 1.32 & 1.39 \\
\hline Gd & 6.1 & 4.7 & 4.5 & 5.9 & 5.6 & 4.2 & 6.1 & 5.9 & 5.9 & 7.7 & 4.8 & 5 & 6.3 & 5.2 & 6.8 & 5.7 & 5.9 \\
\hline $\mathrm{Tb}$ & 1 & 0.8 & 0.7 & 1 & 0.9 & 0.6 & 1 & 0.9 & 0.9 & 1.3 & 0.8 & 0.9 & 1 & 0.8 & 1.1 & 0.9 & 0.9 \\
\hline Dy & 5.6 & 4.7 & 4.3 & 5.6 & 5.4 & 3.7 & 5.5 & 5.4 & 5.7 & 7.4 & 4.4 & 5 & 5.7 & 4.6 & 6.6 & 5.1 & 5.6 \\
\hline Ho & 1.1 & 0.9 & 0.9 & 1.2 & 1.1 & 0.7 & 1.1 & 1.1 & 1.1 & 1.5 & 0.9 & 1 & 1.1 & 0.9 & 1.3 & 1.1 & 1.1 \\
\hline Er & 3.2 & 2.7 & 2.5 & 3.2 & 3.1 & 2 & 3.1 & 3 & 3.1 & 4.1 & 2.6 & 2.8 & 3.3 & 2.5 & 3.6 & 3.1 & 3.1 \\
\hline $\mathrm{Tm}$ & 0.49 & 0.4 & 0.38 & 0.52 & 0.46 & 0.3 & 0.49 & 0.46 & 0.48 & 0.59 & 0.39 & 0.43 & 0.5 & 0.4 & 0.54 & 0.46 & 0.47 \\
\hline $\mathrm{Yb}$ & 3.3 & 2.7 & 2.6 & 3.5 & 3.1 & 2.1 & 3.2 & 3 & 3.2 & 3.7 & 2.6 & 2.9 & 3.2 & 2.6 & 3.7 & 2.9 & 3.2 \\
\hline $\mathrm{Lu}$ & 0.53 & 0.42 & 0.41 & 0.56 & 0.49 & 0.33 & 0.49 & 0.46 & 0.52 & 0.58 & 0.41 & 0.45 & 0.5 & 0.4 & 0.56 & 0.45 & 0.48 \\
\hline Hf & 4.2 & 5.7 & 6.6 & 5.5 & 6.6 & 3.9 & 4.4 & 4.1 & 4.4 & 6.8 & 3.8 & 4.6 & 3.5 & 4.3 & 5 & 3.4 & 3.6 \\
\hline $\mathrm{Ta}$ & 0.9 & 0.8 & 0.7 & 1.1 & 1 & 0.5 & 0.9 & 1.1 & 1.2 & 2.8 & 0.9 & 0.8 & 1.1 & 1 & 1.5 & 1 & 1 \\
\hline $\mathrm{Tl}$ & 0.8 & 0.3 & 0.3 & 0.7 & 0.6 & 0.2 & 0.7 & 0.7 & 0.7 & 0.8 & 0.5 & 0.6 & 0.9 & 0.6 & 0.7 & 0.7 & 0.8 \\
\hline $\mathrm{Pb}$ & 45 & 15 & 19 & 33 & 23 & 11 & 31 & 25 & 22 & 23 & 19 & 16 & 33 & 265 & 33 & 25 & 21 \\
\hline Th & 11.6 & 7.8 & 7.8 & 11.4 & 9.7 & 5.6 & 11 & 10.3 & 11.2 & 14.1 & 8.8 & 9.8 & 12.4 & 9.3 & 11.5 & 12 & 12.2 \\
\hline $\mathrm{U}$ & 2.8 & 2.1 & 2.1 & 3.1 & 2.8 & 1.7 & 3.2 & 3.2 & 3.5 & 4.8 & 2.8 & 3.6 & 4.5 & 3.3 & 3.3 & 3.5 & 3.1 \\
\hline
\end{tabular}


Appendix A. Continued.

Core/ core core core core core core core core core core core core core core core core core $\begin{array}{lllllllllllllllllll}\text { Surface } & 05-04 & 05-04 & 05-04 & 05-04 & 05-04 & 05-04 & 05-04 & 05-04 & 05-04 & 05-04 & 05-04 & 05-04 & 05-04 & 05-04 & 05-04 & 05-04 & 05-04\end{array}$

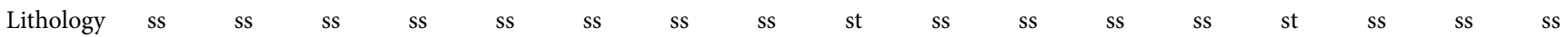

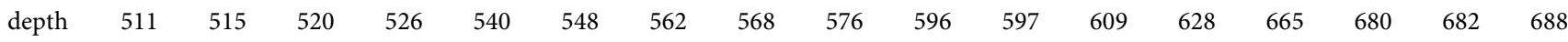
unit upper upper upper upper upper upper lower lower lower lower lower lower lower lower lower lower lower

$\mathrm{SiO}_{2} \quad 716900697600680900733200714000740300712500693700679900698800713100706400674400556200631500533300664500$

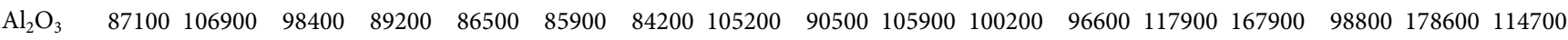
$\begin{array}{llllllllllllllllll}\mathrm{Fe}_{2} \mathrm{O}_{3}{ }^{(\mathrm{T})} & 35500 & 39200 & 49500 & 34300 & 30300 & 34200 & 29300 & 43400 & 35800 & 45100 & 36300 & 38100 & 49600 & 81100 & 40500 & 81100 & 48900\end{array}$ $\begin{array}{lrllllllllllllllll}\mathrm{MnO} & 830 & 640 & 690 & 640 & 710 & 710 & 830 & 650 & 920 & 560 & 730 & 860 & 820 & 700 & 1170 & 710 & 1140\end{array}$ $\begin{array}{llllllllllllllllll}\mathrm{MgO} & 11100 & 15000 & 14400 & 10800 & 10800 & 11700 & 10600 & 14100 & 11200 & 15800 & 14100 & 12400 & 16400 & 28800 & 14000 & 30100 & 18300\end{array}$ $\begin{array}{llllllllllllllllllllll}\mathrm{CaO} & 45800 & 34300 & 39500 & 34800 & 46800 & 36900 & 56800 & 29700 & 56700 & 23800 & 41700 & 43400 & 34300 & 32000 & 71900 & 34400 & 48800\end{array}$ $\begin{array}{lllllllllllllllllll}\mathrm{Na}_{2} \mathrm{O} & 17900 & 13900 & 14000 & 16700 & 16700 & 15400 & 15600 & 15000 & 14100 & 14900 & 16400 & 15800 & 14600 & 10700 & 13100 & 10300 & 13800\end{array}$ $\begin{array}{llllllllllllllllllll}\mathrm{K}_{2} \mathrm{O} & 17500 & 22600 & 21700 & 19600 & 17300 & 16100 & 16600 & 22500 & 19800 & 20900 & 17400 & 17500 & 24500 & 39300 & 18900 & 40900 & 22900\end{array}$

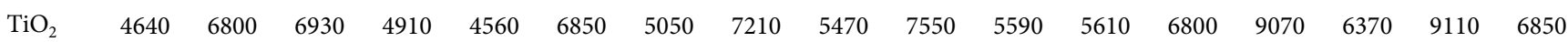
$\begin{array}{llllllllllllllllll}\mathrm{P}_{2} \mathrm{O}_{5} & 800 & 1400 & 1100 & 800 & 1000 & 1200 & 700 & 1400 & 800 & 1200 & 1000 & 1000 & 1100 & 1500 & 1200 & 1500 & 1400\end{array}$

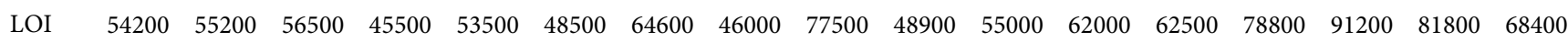

\begin{tabular}{|c|c|c|c|c|c|c|c|c|c|c|c|c|c|c|c|c|c|}
\hline $\mathrm{Sc}$ & 7 & 10 & 10 & 7 & 7 & 8 & 7 & 10 & 8 & 11 & 9 & 8 & 11 & 19 & 9 & 19 & 12 \\
\hline $\mathrm{Be}$ & 1 & 2 & 2 & 1 & 1 & 1 & 1 & 2 & 1 & 2 & 2 & 1 & 2 & 3 & 2 & 3 & 2 \\
\hline V & 52 & 74 & 71 & 50 & 50 & 64 & 54 & 76 & 58 & 82 & 66 & 64 & 82 & 138 & 67 & 137 & 85 \\
\hline $\mathrm{Ba}$ & 350 & 276 & 275 & 809 & 325 & 269 & 360 & 290 & 509 & 265 & 250 & 282 & 360 & 435 & 546 & 470 & 558 \\
\hline Sr & 87 & 86 & 84 & 203 & 179 & 115 & 269 & 97 & 275 & 90 & 113 & 217 & 130 & 178 & 503 & 191 & 221 \\
\hline Y & 21 & 24 & 28 & 20 & 18 & 26 & 21 & 26 & 22 & 26 & 20 & 20 & 24 & 30 & 24 & 30 & 25 \\
\hline $\mathrm{Zr}$ & 229 & 269 & 348 & 267 & 217 & 480 & 247 & 306 & 268 & 337 & 231 & 257 & 251 & 171 & 347 & 158 & 249 \\
\hline $\mathrm{Cr}$ & 60 & 70 & 70 & 60 & 50 & 80 & 60 & 70 & 50 & 70 & 60 & 60 & 70 & 110 & 70 & 110 & 70 \\
\hline Co & 7 & 12 & 12 & 8 & 6 & 8 & 7 & 11 & 9 & 11 & 10 & 9 & 12 & 20 & 11 & 20 & 13 \\
\hline $\mathrm{Zn}$ & 40 & 280 & 290 & 180 & 60 & 60 & 40 & 80 & 60 & 100 & 70 & 90 & 80 & 110 & 130 & 110 & 80 \\
\hline $\mathrm{Ga}$ & 10 & 13 & 13 & 10 & 10 & 10 & 9 & 13 & 10 & 14 & 12 & 11 & 15 & 22 & 11 & 22 & 14 \\
\hline $\mathrm{Ge}$ & 2 & 2 & 2 & 2 & 2 & 2 & 2 & 2 & 2 & 2 & 2 & 2 & 2 & 3 & 2 & 3 & 2 \\
\hline $\mathrm{Rb}$ & 64 & 86 & 81 & 72 & 64 & 62 & 58 & 85 & 70 & 81 & 68 & 66 & 87 & 148 & 66 & 150 & 85 \\
\hline $\mathrm{Nb}$ & 7 & 10 & 11 & 8 & 7 & 10 & 8 & 11 & 8 & 11 & 8 & 8 & 10 & 13 & 9 & 14 & 11 \\
\hline Sn & 2 & 3 & 3 & 2 & 2 & 2 & 2 & 3 & 2 & 3 & 2 & 2 & 3 & 4 & 2 & 4 & 3 \\
\hline Cs & 2.5 & 4.2 & 3.7 & 2.7 & 2.6 & 2.5 & 2.4 & 4.2 & 3.3 & 4.1 & 3.3 & 3 & 4.5 & 8.1 & 3.4 & 8.8 & 4.6 \\
\hline $\mathrm{La}$ & 22.7 & 26.1 & 30.3 & 21.7 & 21.4 & 31.6 & 22.1 & 31.5 & 24.6 & 33.6 & 25.3 & 24.2 & 31.4 & 39.3 & 26.1 & 38.4 & 29.3 \\
\hline $\mathrm{Ce}$ & 47.7 & 58 & 65 & 45.5 & 46.3 & 66.5 & 48.6 & 67.6 & 53.8 & 69.7 & 53.3 & 52.1 & 65.1 & 83.5 & 58 & 81 & 64.9 \\
\hline $\operatorname{Pr}$ & 5.65 & 6.84 & 7.48 & 5.34 & 5.14 & 7.64 & 5.63 & 7.19 & 6.12 & 7.73 & 6.06 & 5.9 & 7.44 & 9.07 & 6.5 & 8.92 & 6.79 \\
\hline $\mathrm{Nd}$ & 21.9 & 27.6 & 30 & 21.2 & 21 & 29.4 & 22.2 & 30 & 25.8 & 29.1 & 23.8 & 22.8 & 27.6 & 36.1 & 26 & 34.9 & 27.7 \\
\hline Sm & 4.6 & 5.8 & 5.8 & 4.6 & 4.1 & 6.2 & 4.8 & 5.8 & 5.3 & 5.3 & 4.6 & 4.8 & 5.2 & 6.5 & 5.5 & 6.8 & 5.7 \\
\hline $\mathrm{Eu}$ & 0.95 & 1.15 & 1.17 & 0.91 & 0.89 & 1.18 & 0.96 & 1.23 & 1.13 & 1.06 & 0.93 & 0.99 & 1.14 & 1.4 & 1.04 & 1.33 & 1.18 \\
\hline Gd & 4.3 & 5.2 & 5 & 3.9 & 3.9 & 5.3 & 4.1 & 5.6 & 4.8 & 4.4 & 4.3 & 4.2 & 4.6 & 5.6 & 5 & 5.6 & 5.1 \\
\hline $\mathrm{Tb}$ & 0.7 & 0.8 & 0.9 & 0.6 & 0.6 & 0.9 & 0.7 & 0.8 & 0.7 & 0.7 & 0.7 & 0.7 & 0.8 & 0.9 & 0.8 & 0.9 & 0.8 \\
\hline Dy & 4.1 & 4.5 & 4.9 & 3.6 & 3.4 & 5.1 & 3.9 & 5 & 4.2 & 4.5 & 3.9 & 3.9 & 4.3 & 5.4 & 4.3 & 5.2 & 4.8 \\
\hline Ho & 0.8 & 0.9 & 1 & 0.7 & 0.6 & 1 & 0.8 & 1 & 0.8 & 0.9 & 0.8 & 0.8 & 0.9 & 1.1 & 0.9 & 1.1 & 0.9 \\
\hline Er & 2.2 & 2.5 & 2.7 & 2 & 1.9 & 2.9 & 2 & 2.8 & 2.3 & 2.7 & 2.3 & 2.2 & 2.5 & 2.9 & 2.5 & 3 & 2.6 \\
\hline $\mathrm{Tm}$ & 0.34 & 0.41 & 0.41 & 0.3 & 0.29 & 0.47 & 0.3 & 0.44 & 0.35 & 0.43 & 0.35 & 0.33 & 0.38 & 0.46 & 0.39 & 0.47 & 0.41 \\
\hline $\mathrm{Yb}$ & 2.2 & 2.7 & 2.7 & 2.1 & 2 & 3.2 & 2 & 3 & 2.3 & 2.9 & 2.4 & 2.2 & 2.6 & 3.1 & 2.6 & 3 & 2.8 \\
\hline $\mathrm{Lu}$ & 0.34 & 0.42 & 0.46 & 0.33 & 0.31 & 0.49 & 0.33 & 0.47 & 0.37 & 0.45 & 0.38 & 0.37 & 0.42 & 0.47 & 0.43 & 0.46 & 0.44 \\
\hline Hf & 4.8 & 6.2 & 7.3 & 5.8 & 4.9 & 10.4 & 5.4 & 7.1 & 5.9 & 7.1 & 5 & 5.4 & 5.4 & 3.9 & 7.5 & 3.5 & 5.7 \\
\hline $\mathrm{Ta}$ & 0.9 & 0.9 & 0.8 & 0.5 & 0.8 & 1.1 & 0.7 & 1 & 0.7 & 0.9 & 0.7 & 0.7 & 1.1 & 0.9 & 0.8 & 1.1 & 1 \\
\hline $\mathrm{Tl}$ & 0.3 & 0.4 & 0.4 & 0.3 & 0.5 & 0.3 & 0.3 & 0.5 & 0.4 & 0.4 & 0.3 & 0.3 & 0.4 & 0.8 & 0.3 & 0.7 & 0.5 \\
\hline $\mathrm{Pb}$ & 8 & 103 & 96 & 62 & 9 & 12 & 9 & 20 & 16 & 25 & 13 & 26 & 21 & 25 & 48 & 20 & 17 \\
\hline Th & 6.9 & 8.3 & 9.1 & 7.1 & 5.5 & 9.7 & 6.5 & 7.5 & 7.3 & 9.4 & 7.4 & 7 & 8.8 & 11.4 & 8 & 11.9 & 7.5 \\
\hline $\mathrm{U}$ & 1.7 & 2.4 & 2.2 & 1.7 & 1.5 & 2.6 & 1.8 & 2.4 & 2.1 & 2.8 & 2.1 & 2 & 2.6 & 3.2 & 2.4 & 3.1 & 2.3 \\
\hline
\end{tabular}


Appendix A. Continued.

\begin{tabular}{|c|c|c|c|c|c|c|c|c|c|c|c|c|c|c|c|c|c|}
\hline Core/ & core & core & core & core & core & core & core & core & core & core & core & core & core & core & core & core & core \\
\hline Surface & 05-04 & 05-04 & 05-04 & 05-04 & 05-04 & 05-04 & 02-05 & 02-05 & $02-05$ & $02-05$ & $02-05$ & $02-05$ & $02-05$ & 02-05 & $02-05$ & $02-05$ & 02-05 \\
\hline Lithology & ss & st & st & st & st & st & ss & $\mathrm{cg}$ & ss & ss & ss & ss & ss & ss & ss & ss & ss \\
\hline depth & 691 & 716 & 736 & 759 & 763 & 769 & 255 & 265 & 275 & 285 & 295 & 305 & 315 & 325 & 335 & 345 & 355 \\
\hline unit & lower & lower & lower & lower & lower & lower & upper & upper & upper & upper & upper & upper & upper & upper & upper & upper & upper \\
\hline $\mathrm{SiO}_{2}$ & 678400 & 572800 & 539300 & 527000 & 479000 & 537200 & 675800 & 726800 & 505300 & 536500 & 733200 & 686500 & 649000 & 720400 & 719100 & 680900 & 718200 \\
\hline $\mathrm{Al}_{2} \mathrm{O}_{3}$ & 93600 & 147800 & 174000 & 173000 & 185000 & 179400 & 112500 & 124400 & 87700 & 77400 & 115300 & 138000 & 118900 & 112400 & 110300 & 128600 & 121600 \\
\hline $\mathrm{Fe}_{2} \mathrm{O}_{3}{ }^{(\mathrm{T})}$ & 32200 & 67300 & 77000 & 85100 & 92300 & 77900 & 41000 & 27600 & 34100 & 25000 & 47200 & 53500 & 47400 & 46900 & 41700 & 54100 & 51400 \\
\hline $\mathrm{MnO}$ & 1410 & 850 & 740 & 800 & 810 & 710 & 780 & 530 & 730 & 880 & 630 & 750 & 850 & 480 & 620 & 730 & 46 \\
\hline $\mathrm{MgO}$ & 14400 & 26200 & 29200 & 34800 & 47100 & 34100 & 16400 & 16700 & 13900 & 11500 & 18400 & 21700 & 17300 & 19000 & 15600 & 18900 & 18700 \\
\hline $\mathrm{CaO}$ & 59700 & 48600 & 30200 & 32900 & 32100 & 29200 & 48800 & 14500 & 170700 & 170400 & 7800 & 11200 & 58200 & 4400 & 16000 & 26200 & 6400 \\
\hline $\mathrm{Na}_{2} \mathrm{O}$ & 14500 & 10700 & 9700 & 10300 & 7700 & 9700 & 21500 & 27700 & 10200 & 17400 & 18600 & 27500 & 26300 & 15000 & 21100 & 26000 & 22500 \\
\hline $\mathrm{K}_{2} \mathrm{O}$ & 18400 & 34300 & 42100 & 41300 & 44100 & 43400 & 23400 & 24100 & 22100 & 14000 & 23600 & 25000 & 22200 & 26700 & 24600 & 26000 & 25900 \\
\hline $\mathrm{TiO}_{2}$ & 6680 & 8190 & 8530 & 8900 & 8230 & 8280 & 7480 & 8030 & 6260 & 6090 & 9280 & 8220 & 7940 & 7970 & 7480 & 8240 & 7980 \\
\hline $\mathrm{P}_{2} \mathrm{O}_{5}$ & 1200 & 1100 & 1200 & 1300 & 1300 & 1300 & 1300 & 1300 & 900 & 1000 & 1500 & 1400 & 1200 & 1100 & 700 & 1400 & 1400 \\
\hline LOI & 63000 & 85600 & 84300 & 84000 & 101600 & 83600 & 56100 & 27200 & 155500 & 145100 & 29600 & 26000 & 57800 & 29500 & 29700 & 36800 & 26600 \\
\hline Sc & 9 & 16 & 18 & 19 & 21 & 19 & 11 & 12 & 8 & 8 & 12 & 13 & 12 & 11 & 10 & 14 & 1 \\
\hline $\mathrm{Be}$ & 2 & 3 & 3 & 3 & 3 & 3 & 2 & 2 & 1 & 1 & 2 & 2 & 1 & 2 & 1 & 2 & \\
\hline $\mathrm{V}$ & 64 & 115 & 123 & 141 & 177 & 131 & 85 & 80 & 67 & 56 & 95 & 97 & 86 & 86 & 80 & 97 & 8 \\
\hline $\mathrm{Ba}$ & 263 & 395 & 548 & 467 & 395 & 490 & 368 & 952 & 698 & 271 & 413 & 600 & 404 & 412 & 441 & 412 & 39 \\
\hline $\mathrm{Sr}$ & 166 & 209 & 245 & 193 & 169 & 221 & 128 & 141 & 137 & 148 & 99 & 151 & 149 & 81 & 117 & 136 & 107 \\
\hline $\mathrm{Y}$ & 28 & 28 & 29 & 30 & 24 & 30 & 24 & 25 & 34 & 29 & 31 & 24 & 27 & 26 & 25 & 26 & 2 \\
\hline $\mathrm{Zr}$ & 391 & 204 & 172 & 166 & 124 & 173 & 314 & 299 & 264 & 283 & 370 & 241 & 326 & 303 & 336 & 249 & 29 \\
\hline $\mathrm{Cr}$ & 80 & 90 & 100 & 110 & 140 & 90 & 50 & 40 & 40 & 40 & 60 & 30 & 40 & 50 & 40 & 40 & 6 \\
\hline Co & 10 & 17 & 20 & 20 & 25 & 20 & 10 & 10 & 5 & 2 & 12 & 11 & 8 & 13 & 8 & 11 & 1 \\
\hline $\mathrm{Zn}$ & 50 & 100 & 100 & 100 & 280 & 100 & 60 & 50 & 40 & 40 & 60 & 60 & 50 & 80 & 50 & 60 & 8 \\
\hline $\mathrm{Ga}$ & 11 & 19 & 22 & 22 & 24 & 22 & 11 & 12 & 9 & 7 & 12 & 12 & 11 & 14 & 10 & 11 & 1 \\
\hline $\mathrm{Ge}$ & 2 & 3 & 3 & 3 & 3 & 3 & 1 & 1 & 1 & 1 & 2 & 1 & 1 & 2 & 1 & 1 & \\
\hline $\mathrm{Rb}$ & 66 & 125 & 157 & 155 & 163 & 155 & 70 & 69 & 65 & 40 & 71 & 72 & 61 & 92 & 68 & 72 & 8 \\
\hline $\mathrm{Nb}$ & 10 & 13 & 14 & 14 & 12 & 14 & 13 & 12 & 12 & 11 & 16 & 10 & 12 & 14 & 13 & 11 & 1 \\
\hline Sn & 2 & 3 & 4 & 4 & 5 & 4 & 2 & 2 & 2 & 2 & 3 & 2 & 2 & 2 & 2 & 2 & \\
\hline Cs & 3.4 & 7.3 & 9.1 & 9.1 & 9.4 & 9.1 & 3.4 & 2.8 & 4.1 & 2 & 3.9 & 3.6 & 2.9 & 4.1 & 3.1 & 3.8 & 3.9 \\
\hline $\mathrm{La}$ & 7.8 & 32 & 3.9 & 43.6 & 35.6 & 38.1 & 28.7 & 30.1 & 35.8 & 23.1 & 37.1 & 35.1 & 30.6 & 39.3 & 25.9 & 36.8 & 36.2 \\
\hline $\mathrm{Ce}$ & 62.5 & 67.5 & 83.7 & 91.7 & 74.5 & 81.4 & 56.3 & 62.6 & 58.1 & 47.3 & 78 & 73.7 & 59.3 & 71.2 & 62.8 & 63.3 & 60.1 \\
\hline $\operatorname{Pr}$ & 7.32 & 7.58 & 9.27 & 9.76 & 8.12 & 8.86 & 6.31 & 7.35 & 8.71 & 6.13 & 8.47 & 7.82 & 6.9 & 7.12 & 7.03 & 7.05 & 6.63 \\
\hline $\mathrm{Nd}$ & 29 & 29.4 & 36.4 & 35.9 & 29.6 & 33.9 & 23.2 & 28.1 & 33.8 & 23.8 & 31.8 & 28.2 & 25.6 & 26.1 & 28.4 & 25.4 & 22.4 \\
\hline $\mathrm{Sm}$ & 6.3 & 6.1 & 6.6 & 6.6 & 5.8 & 6.9 & 4.5 & 5.4 & 6.7 & 4.8 & 6.3 & 5.1 & 5.1 & 5.2 & 5.8 & 5.2 & 4.5 \\
\hline $\mathrm{Eu}$ & 1.27 & 1.27 & 1.33 & 1.32 & 1.21 & 1.33 & 0.96 & 1.09 & 1.38 & 0.99 & 1.26 & 1.06 & 1.14 & 1.05 & 1.17 & 1.17 & 0.99 \\
\hline $\mathrm{Gd}$ & 5.9 & 5.4 & 5.8 & 5.6 & 4.8 & 5.8 & 4.1 & 4.4 & 6 & 4.2 & 5.4 & 4.1 & 4.4 & 4.6 & 4.8 & 4.5 & 4. \\
\hline $\mathrm{Tb}$ & 0.9 & 0.9 & 0.9 & 0.9 & 0.8 & 0.9 & 0.7 & 0.7 & 0.9 & 0.7 & 0.9 & 0.7 & 0.7 & 0.8 & 0.7 & 0.8 & 0.7 \\
\hline Dy & 4.9 & 5 & 5.3 & 5.6 & 4.6 & 5.4 & 4.1 & 4.1 & 5.5 & 4.2 & 5.3 & 4 & 4.4 & 4.9 & 4.2 & 4.5 & 4. \\
\hline Ho & 1 & 1 & 1.1 & 1.1 & 0.9 & 1.1 & 0.8 & 0.8 & 1.1 & 0.9 & 1.1 & 0.8 & 0.9 & 1 & 0.9 & 0.9 & 0.9 \\
\hline Er & 2.8 & 2.9 & 2.9 & 3.1 & 2.5 & 2.9 & 2.6 & 2.5 & 3.1 & 2.5 & 3.1 & 2.4 & 2.6 & 3 & 2.5 & 2.6 & 2.6 \\
\hline $\mathrm{Tm}$ & 0.42 & 0.44 & 0.44 & 0.45 & 0.39 & 0.48 & 0.4 & 0.39 & 0.46 & 0.4 & 0.48 & 0.38 & 0.4 & 0.46 & 0.39 & 0.4 & 0.42 \\
\hline $\mathrm{Yb}$ & 2.9 & 2.9 & 2.9 & 3.2 & 2.7 & 3.2 & 2.7 & 2.7 & 3.2 & 2.6 & 3.3 & 2.6 & 2.8 & 3.1 & 2.7 & 2.7 & 2.9 \\
\hline $\mathrm{Lu}$ & 0.46 & 0.43 & 0.46 & 0.51 & 0.42 & 0.49 & 0.47 & 0.47 & 0.55 & 0.45 & 0.56 & 0.46 & 0.47 & 0.53 & 0.46 & 0.45 & 0.5 \\
\hline $\mathrm{Hf}$ & 8.3 & 4.5 & 3.8 & 3.9 & 3 & 4.2 & 8.9 & 8.6 & 7.6 & 8.3 & 10.7 & 6.8 & 9.3 & 8.1 & 9.5 & 7.1 & 8.7 \\
\hline $\mathrm{Ta}$ & 0.8 & 1.1 & 1 & 1 & 0.9 & 1 & 0.8 & 0.8 & 0.8 & 0.7 & 1.1 & 0.8 & 0.7 & 0.9 & 0.8 & 0.8 & \\
\hline $\mathrm{Tl}$ & 0.3 & 0.6 & 0.7 & 0.7 & 0.7 & 0.7 & 0.3 & 0.3 & 0.3 & 0.2 & 0.4 & 0.3 & 0.3 & 0.4 & 0.3 & 0.3 & 0.4 \\
\hline $\mathrm{Pb}$ & 11 & 26 & 25 & 25 & 66 & 22 & 34 & 9 & 18 & 13 & 29 & 22 & 19 & 15 & 22 & 20 & 21 \\
\hline Th & 8.8 & 10.2 & 11.4 & 12.2 & 11.2 & 11.9 & 9.1 & 9.3 & 7.6 & 7 & 9.8 & 9.3 & 9.2 & 8.1 & 8.6 & 9.3 & 9.7 \\
\hline $\mathrm{U}$ & 2.7 & 2.9 & 3.1 & 3 & 3.6 & 3.4 & 2.7 & 2.2 & 2.5 & 2.3 & 3.1 & 2.7 & 2.5 & 2.5 & 2.6 & 2.9 & 2. \\
\hline
\end{tabular}


Appendix A. Continued.

Core/ core core core core core core core core core core core core core core core core core

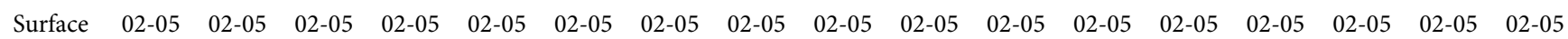
$\begin{array}{llllllllllllllllll}\text { Lithology } & \mathrm{cg} & \mathrm{ss} & \mathrm{ss} & \mathrm{cg} & \mathrm{ss} & \mathrm{ss} & \mathrm{ss} & \mathrm{ss} & \mathrm{ss} & \mathrm{ss} & \mathrm{ss} & \mathrm{ss} & \mathrm{cg} & \mathrm{ss} & \mathrm{cg} & \text { ss } & \text { ss }\end{array}$

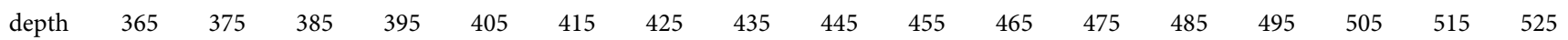
unit upper upper upper upper upper upper upper upper upper upper upper upper upper upper upper upper upper

$\mathrm{SiO}_{2} \quad 646000746300742100678200590600706100641700522100600700696300668700336600690900680900638700647900689300$

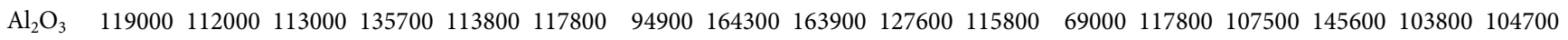
$\begin{array}{llllllllllllllllll}\mathrm{Fe}_{2} \mathrm{O}_{3}{ }^{(\mathrm{T})} & 36100 & 44400 & 42800 & 55800 & 46600 & 44200 & 45000 & 56400 & 82100 & 42700 & 39500 & 36300 & 47400 & 40000 & 71600 & 40400 & 38000\end{array}$

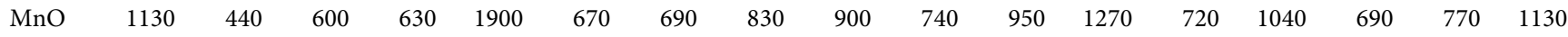
$\begin{array}{llllllllllllllllll}\mathrm{MgO} & 14700 & 17000 & 15500 & 25400 & 15400 & 17000 & 14600 & 33500 & 32700 & 16600 & 16100 & 12700 & 18100 & 16300 & 24300 & 16900 & 13400\end{array}$ $\begin{array}{llllllllllllllllll}\mathrm{CaO} & 66700 & 7500 & 14700 & 13900 & 98400 & 16000 & 82000 & 61700 & 5800 & 26500 & 52000 & 278900 & 31100 & 52100 & 9500 & 64900 & 51500\end{array}$ $\begin{array}{lllllllllllllllllll}\mathrm{Na}_{2} \mathrm{O} & 28800 & 21500 & 26400 & 15000 & 26900 & 19800 & 16600 & 5600 & 10700 & 32200 & 27500 & 7500 & 21400 & 23800 & 17500 & 16300 & 26600\end{array}$ $\begin{array}{lllllllllllllllllll}\mathrm{K}_{2} \mathrm{O} & 23900 & 26000 & 23500 & 30900 & 20100 & 28100 & 21900 & 47700 & 40400 & 22800 & 22300 & 18600 & 26500 & 23100 & 34400 & 25100 & 20800\end{array}$

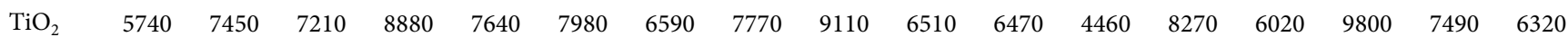
$\begin{array}{llllllllllllllllll}\mathrm{P}_{2} \mathrm{O}_{5} & 1200 & 1300 & 1400 & 1400 & 1500 & 600 & 1200 & 1100 & 1400 & 1400 & 1500 & 1100 & 1400 & 1200 & 1300 & 1000 & 1400\end{array}$ LOI $\quad \begin{array}{llllllllllllllllllll} & 61800 & 23600 & 18400 & 42000 & 77900 & 30700 & 78400 & 98100 & 47800 & 28400 & 49300 & 235200 & 44800 & 56500 & 44600 & 72000 & 47500\end{array}$

\begin{tabular}{|c|c|c|c|c|c|c|c|c|c|c|c|c|c|c|c|c|c|}
\hline $\mathrm{Sc}$ & 10 & 11 & 10 & 13 & 12 & 12 & 9 & 17 & 17 & 11 & 10 & 7 & 12 & 10 & 15 & 10 & 9 \\
\hline $\mathrm{Be}$ & 1 & 2 & 1 & 2 & 1 & 2 & 1 & 4 & 4 & 1 & 1 & 1 & 2 & 2 & 3 & 2 & 1 \\
\hline V & 67 & 83 & 74 & 88 & 85 & 85 & 64 & 119 & 124 & 80 & 72 & 56 & 92 & 69 & 119 & 84 & 65 \\
\hline $\mathrm{Ba}$ & 561 & 466 & 418 & 407 & 387 & 453 & 326 & 433 & 468 & 454 & 417 & 210 & 372 & 362 & 418 & 568 & 379 \\
\hline Sr & 150 & 104 & 143 & 90 & 208 & 106 & 110 & 87 & 89 & 165 & 159 & 182 & 113 & 121 & 84 & 104 & 150 \\
\hline $\mathrm{Y}$ & 22 & 23 & 24 & 30 & 31 & 24 & 26 & 29 & 33 & 21 & 24 & 23 & 30 & 24 & 32 & 30 & 24 \\
\hline $\mathrm{Zr}$ & 188 & 317 & 324 & 308 & 225 & 344 & 266 & 171 & 273 & 196 & 227 & 160 & 434 & 251 & 292 & 321 & 225 \\
\hline $\mathrm{Cr}$ & 20 & 40 & 40 & 70 & 40 & 100 & 50 & 90 & 90 & 30 & 40 & 40 & 50 & 40 & 90 & 60 & 40 \\
\hline Co & 7 & 10 & 9 & 17 & 6 & 11 & 8 & 19 & 21 & 9 & 9 & 0.9 & 10 & 8 & 18 & 11 & 7 \\
\hline $\mathrm{Zn}$ & 60 & 60 & 70 & 120 & 60 & 80 & 60 & 150 & 130 & 60 & 60 & 50 & 80 & 80 & 130 & 100 & 60 \\
\hline $\mathrm{Ga}$ & 12 & 12 & 13 & 19 & 13 & 15 & 11 & 24 & 24 & 14 & 13 & 9 & 13 & 12 & 22 & 14 & 11 \\
\hline $\mathrm{Ge}$ & 1 & 2 & 2 & 2 & 1 & 2 & 2 & 2 & 3 & 1 & 2 & 1 & 2 & 2 & 2 & 2 & 2 \\
\hline $\mathrm{Rb}$ & 69 & 74 & 73 & 112 & 61 & 96 & 69 & 171 & 152 & 72 & 68 & 62 & 82 & 72 & 133 & 104 & 65 \\
\hline $\mathrm{Nb}$ & 11 & 13 & 11 & 18 & 11 & 14 & 13 & 17 & 27 & 10 & 10 & 9 & 16 & 10 & 20 & 15 & 9 \\
\hline Sn & 1 & 2 & 1 & 2 & 1 & 2 & 1 & 3 & 4 & 1 & 1 & 0.9 & 3 & 1 & 3 & 2 & 1 \\
\hline Cs & 2.6 & 3.4 & 2.6 & 6.1 & 2.1 & 4.4 & 2.9 & 11 & 9.6 & 2.7 & 2.4 & 3.7 & 4.4 & 3 & 7.9 & 5.1 & 2.5 \\
\hline $\mathrm{La}$ & 35.7 & 34.3 & 29.6 & 43.6 & 32.9 & 24.9 & 30.2 & 40.9 & 43.2 & 29.7 & 31.2 & 22 & 39.5 & 26.6 & 43.9 & 33.4 & 28.9 \\
\hline $\mathrm{Ce}$ & 62 & 55.8 & 58.6 & 68.4 & 74.8 & 48.2 & 48.9 & 61.6 & 81.3 & 56.3 & 53.4 & 45.7 & 67.9 & 46.5 & 73.4 & 42.9 & 54.5 \\
\hline $\operatorname{Pr}$ & 7.24 & 5.98 & 6.58 & 7.4 & 8.71 & 5.45 & 6.17 & 6.92 & 8.62 & 6.4 & 6.3 & 5.73 & 7.35 & 5.46 & 7.94 & 5.94 & 6.35 \\
\hline $\mathrm{Nd}$ & 25.9 & 21.4 & 23.5 & 25.4 & 31.1 & 19.3 & 21.6 & 23 & 29 & 23.1 & 21.9 & 20.5 & 26.6 & 19.7 & 27.6 & 21 & 22.3 \\
\hline Sm & 4.7 & 4.2 & 4.8 & 5.5 & 6.2 & 4 & 4.6 & 4.8 & 6.5 & 4.7 & 4.5 & 4.3 & 5.4 & 4.1 & 6 & 4.6 & 4.6 \\
\hline $\mathrm{Eu}$ & 0.99 & 0.91 & 1.06 & 1.17 & 1.41 & 0.88 & 0.98 & 1.05 & 1.3 & 1.07 & 1.03 & 0.94 & 1.03 & 0.9 & 1.27 & 0.97 & 1.03 \\
\hline Gd & 3.8 & 3.9 & 4.2 & 5 & 5.3 & 3.7 & 4.1 & 4.4 & 5.7 & 3.8 & 3.8 & 4 & 5 & 3.6 & 5.3 & 4.3 & 4.1 \\
\hline $\mathrm{Tb}$ & 0.6 & 0.7 & 0.7 & 0.9 & 0.8 & 0.7 & 0.7 & 0.8 & 1 & 0.6 & 0.7 & 0.7 & 0.9 & 0.6 & 0.9 & 0.8 & 0.7 \\
\hline Dy & 3.7 & 4.1 & 4.1 & 5.4 & 4.9 & 4.3 & 4.4 & 5.2 & 6.3 & 3.7 & 3.9 & 3.9 & 5.2 & 3.8 & 5.8 & 5 & 4 \\
\hline Ho & 0.7 & 0.8 & 0.8 & 1.1 & 1 & 0.9 & 0.9 & 1.1 & 1.3 & 0.7 & 0.8 & 0.8 & 1.1 & 0.8 & 1.2 & 1 & 0.8 \\
\hline Er & 2.2 & 2.5 & 2.4 & 3.2 & 2.8 & 2.7 & 2.6 & 3.1 & 3.6 & 2.1 & 2.3 & 2.1 & 3.1 & 2.3 & 3.5 & 3 & 2.3 \\
\hline $\mathrm{Tm}$ & 0.33 & 0.39 & 0.38 & 0.5 & 0.41 & 0.42 & 0.41 & 0.48 & 0.56 & 0.33 & 0.35 & 0.31 & 0.47 & 0.35 & 0.53 & 0.48 & 0.35 \\
\hline $\mathrm{Yb}$ & 2.4 & 2.7 & 2.6 & 3.4 & 2.8 & 2.9 & 2.8 & 3.3 & 3.8 & 2.2 & 2.4 & 2.1 & 3.3 & 2.4 & 3.6 & 3.3 & 2.4 \\
\hline $\mathrm{Lu}$ & 0.41 & 0.45 & 0.44 & 0.57 & 0.45 & 0.51 & 0.46 & 0.55 & 0.64 & 0.36 & 0.41 & 0.32 & 0.55 & 0.39 & 0.6 & 0.57 & 0.4 \\
\hline $\mathrm{Hf}$ & 5.5 & 8.5 & 9.2 & 9.3 & 6.5 & 10.2 & 7.8 & 5.4 & 8.1 & 5.7 & 6.6 & 4.6 & 12 & 7 & 8.9 & 9.5 & 6.5 \\
\hline $\mathrm{Ta}$ & 0.6 & 0.8 & 0.8 & 1.2 & 0.7 & 1 & 0.8 & 1.1 & 1.8 & 0.7 & 0.7 & 0.6 & 1.1 & 0.7 & 1.4 & 1 & 0.7 \\
\hline $\mathrm{Tl}$ & 0.3 & 0.4 & 0.3 & 0.5 & 0.3 & 0.4 & 0.3 & 0.9 & 0.8 & 0.3 & 0.3 & 0.3 & 0.4 & 0.3 & 0.7 & 0.5 & 0.3 \\
\hline $\mathrm{Pb}$ & 13 & 20 & 18 & 20 & 15 & 15 & 17 & 15 & 43 & 16 & 13 & 26 & 27 & 16 & 34 & 20 & 16 \\
\hline Th & 7.1 & 8.7 & 8.4 & 11.2 & 7.8 & 9.8 & 7.3 & 11.2 & 12.7 & 10.5 & 8.2 & 5.5 & 10.6 & 7.4 & 12.1 & 9.1 & 7.5 \\
\hline $\mathrm{U}$ & 2 & 2.7 & 2.2 & 3.2 & 2 & 2.9 & 2.3 & 3.9 & 3.4 & 2.2 & 2 & 2.2 & 3.4 & 1.9 & 3.4 & 3.3 & 1.9 \\
\hline
\end{tabular}


Appendix A. Continued.

\begin{tabular}{|c|c|c|c|c|c|c|c|c|c|c|c|c|c|c|c|c|c|}
\hline Core/ & core & core & core & core & core & core & core & core & core & core & core & core & core & core & core & core & core \\
\hline Surface & $02-05$ & $02-05$ & $02-05$ & $02-05$ & $02-05$ & $02-05$ & $02-05$ & 02-05 & $02-05$ & $02-05$ & $02-05$ & $02-05$ & $02-05$ & $02-05$ & $02-05$ & $02-05$ & 02-05 \\
\hline Lithology & $\mathrm{cg}$ & ss & ss & ss & ss & $\mathrm{cg}$ & ss & ss & st & st & st & ss & ss & ss & ss & ss & ss \\
\hline depth & 535 & 545 & 555 & 565 & 575 & 585 & 595 & 605 & 615 & 625 & 635 & 645 & 655 & 665 & 675 & 685 & 695 \\
\hline unit & upper & upper & upper & upper & upper & upper & upper & upper & upper & upper & upper & upper & upper & upper & upper & upper & lower \\
\hline $\mathrm{SiO}_{2}$ & 706900 & 704000 & 604000 & 690800 & 676000 & 678200 & 741700 & 684500 & 317600 & 511700 & 499500 & 321600 & 544400 & 724400 & 550800 & 732700 & 568700 \\
\hline $\mathrm{Al}_{2} \mathrm{O}_{3}$ & 115900 & 123700 & 125400 & 118400 & 103600 & 128700 & 93900 & 120800 & 77100 & 135600 & 93000 & 104800 & 93300 & 110300 & 208800 & 81400 & 145700 \\
\hline $\mathrm{Fe}_{2} \mathrm{O}_{3}^{(\mathrm{T})}$ & 42000 & 49100 & 32300 & 47400 & 47700 & 49200 & 34700 & 44400 & 33800 & 55400 & 25100 & 44300 & 35300 & 48000 & 66200 & 33500 & 66200 \\
\hline $\mathrm{MnO}$ & 770 & 640 & 1000 & 990 & 1450 & 780 & 1050 & 770 & 560 & 720 & 760 & 410 & 890 & 580 & 480 & 960 & 560 \\
\hline $\mathrm{MgO}$ & 15100 & 18300 & 18600 & 17900 & 14200 & 17100 & 12300 & 17800 & 12400 & 23900 & 12600 & 16200 & 12800 & 14900 & 30700 & 10500 & 20000 \\
\hline $\mathrm{CaO}$ & 29600 & 18400 & 86200 & 28500 & 51300 & 22800 & 36400 & 33300 & 193700 & 76800 & 124300 & 186400 & 115900 & 24000 & 7900 & 47000 & 54000 \\
\hline $\mathrm{Na}_{2} \mathrm{O}$ & 29700 & 31200 & 29000 & 20800 & 27600 & 26700 & 21500 & 21700 & 8300 & 15800 & 13300 & 6100 & 13500 & 14000 & 9500 & 15700 & 11500 \\
\hline $\mathrm{K}_{2} \mathrm{O}$ & 22500 & 23200 & 23900 & 24700 & 16600 & 26400 & 16100 & 25300 & 18900 & 29600 & 20800 & 26900 & 21400 & 24100 & 52100 & 16300 & 35800 \\
\hline $\mathrm{TiO}_{2}$ & 6580 & 8110 & 7570 & 7910 & 9950 & 7640 & 7390 & 7610 & 4090 & 6540 & 5980 & 5050 & 5070 & 7260 & 9770 & 5060 & 7970 \\
\hline $\mathrm{P}_{2} \mathrm{O}_{5}$ & 1400 & 1600 & 1000 & 1300 & 1900 & 1600 & 2000 & 1500 & 900 & 1800 & 1400 & 1100 & 1100 & 1600 & 1900 & 1200 & 1300 \\
\hline LOI & 34100 & 28000 & 78300 & 45100 & 48100 & 38200 & 39700 & 47000 & 138400 & 83400 & 104400 & 90900 & 96500 & 41000 & 60600 & 53700 & 71700 \\
\hline $\mathrm{Sc}$ & 10 & 13 & 13 & 11 & 12 & 12 & 9 & 11 & 8 & 13 & 9 & 11 & 9 & 10 & 21 & 7 & 16 \\
\hline $\mathrm{Be}$ & 1 & 2 & 2 & 2 & 1 & 2 & 1 & 2 & 1 & 2 & 1 & 2 & 2 & 2 & 4 & 1 & 3 \\
\hline $\mathrm{V}$ & 75 & 91 & 101 & 73 & 81 & 92 & 68 & 90 & 64 & 101 & 127 & 87 & 64 & 75 & 161 & 49 & 112 \\
\hline $\mathrm{Ba}$ & 909 & 689 & 391 & 344 & 288 & 406 & 244 & 344 & 363 & 451 & 662 & 342 & 539 & 272 & 462 & 320 & 736 \\
\hline $\mathrm{Sr}$ & 200 & 184 & 190 & 108 & 164 & 139 & 253 & 288 & 935 & 771 & 2751 & 1542 & 1205 & 85 & 93 & 311 & 664 \\
\hline $\mathrm{Y}$ & 23 & 26 & 25 & 27 & 37 & 25 & 33 & 29 & 15 & 24 & 20 & 19 & 19 & 24 & 30 & 22 & 28 \\
\hline $\mathrm{Zr}$ & 270 & 336 & 278 & 282 & 633 & 309 & 397 & 329 & 108 & 194 & 241 & 89 & 207 & 349 & 165 & 260 & 206 \\
\hline $\mathrm{Cr}$ & 40 & 50 & 50 & 60 & 60 & 60 & 70 & 70 & 30 & 50 & 40 & 70 & 40 & 80 & 130 & 60 & 90 \\
\hline Co & 9 & 11 & 11 & 13 & 8 & 11 & 9 & 13 & 5 & 15 & 8 & 8 & 7 & 12 & 28 & 7 & 17 \\
\hline $\mathrm{Zn}$ & 60 & 70 & 70 & 80 & 60 & 80 & 60 & 80 & 70 & 160 & 70 & 80 & 90 & 70 & 120 & 50 & 90 \\
\hline $\mathrm{Ga}$ & 13 & 14 & 15 & 15 & 12 & 15 & 11 & 14 & 10 & 15 & 10 & 14 & 11 & 14 & 28 & 10 & 19 \\
\hline $\mathrm{Ge}$ & 2 & 2 & 2 & 2 & 2 & 2 & 2 & 2 & 0.9 & 1 & 1 & 1 & 1 & 2 & 2 & 2 & 2 \\
\hline $\mathrm{Rb}$ & 72 & 79 & 85 & 87 & 54 & 86 & 53 & 88 & 63 & 89 & 66 & 96 & 70 & 86 & 184 & 55 & 124 \\
\hline $\mathrm{Nb}$ & 12 & 13 & 12 & 13 & 14 & 14 & 13 & 14 & 9 & 11 & 10 & 9 & 13 & 16 & 19 & 10 & 15 \\
\hline Sn & 1 & 2 & 1 & 2 & 1 & 2 & 1 & 2 & 1 & 3 & 2 & 1 & 2 & 2 & 4 & 1 & 3 \\
\hline Cs & 2.8 & 3.4 & 3.6 & 4.7 & 2.4 & 4.1 & 2.4 & 4.5 & 3.9 & 6.3 & 4.1 & 6.1 & 3.9 & 4.6 & 10.6 & 2.5 & 7.3 \\
\hline $\mathrm{La}$ & 32 & 38.3 & 23.5 & 34.3 & 38.3 & 32 & 31.6 & 27.4 & 29.2 & 31.8 & 25.6 & 25.5 & 28.5 & 33.4 & 51.4 & 23.9 & 41.7 \\
\hline $\mathrm{Ce}$ & 55.7 & 72.4 & 48.5 & 58.4 & 77.8 & 61.4 & 66.1 & 57.4 & 51.9 & 62.5 & 49.5 & 49 & 53.3 & 64.1 & 97.1 & 48.2 & 80.6 \\
\hline $\operatorname{Pr}$ & 6.36 & 8.41 & 5.96 & 6.49 & 8.86 & 6.91 & 8.11 & 7.18 & 5.4 & 6.96 & 5.62 & 5.64 & 6.2 & 7.33 & 10.7 & 5.93 & 9.02 \\
\hline $\mathrm{Nd}$ & 22.2 & 30.2 & 21.2 & 22 & 31.4 & 24.4 & 30.6 & 26.5 & 18.2 & 26.3 & 21.3 & 20 & 23.4 & 25.6 & 35.2 & 22.5 & 31 \\
\hline $\mathrm{Sm}$ & 4.6 & 5.9 & 4.4 & 4.7 & 6.4 & 5.1 & 6.8 & 5.7 & 3.4 & 5.4 & 4.4 & 3.9 & 5 & 5.2 & 6.5 & 5 & 5.6 \\
\hline $\mathrm{Eu}$ & 1.02 & 1.21 & 1.06 & 1.04 & 1.38 & 1.08 & 1.35 & 1.17 & 0.67 & 1.13 & 0.86 & 0.84 & 1 & 1 & 1.34 & 1 & 1.14 \\
\hline $\mathrm{Gd}$ & 4.1 & 5.1 & 3.9 & 4.3 & 5.8 & 4.4 & 5.9 & 4.9 & 2.7 & 4.7 & 3.9 & 3.4 & 3.9 & 4.3 & 5.4 & 4.4 & 4.7 \\
\hline $\mathrm{Tb}$ & 0.7 & 0.8 & 0.7 & 0.8 & 1 & 0.7 & 1 & 0.8 & 0.4 & 0.8 & 0.6 & 0.6 & 0.6 & 0.7 & 0.9 & 0.7 & 0.8 \\
\hline Dy & 4.1 & 4.8 & 4.1 & 4.8 & 6 & 4.5 & 5.6 & 4.8 & 2.6 & 4.5 & 3.7 & 3.4 & 3.6 & 4.3 & 5.3 & 4 & 4.8 \\
\hline Ho & 0.8 & 1 & 0.8 & 1 & 1.2 & 0.9 & 1.1 & 1 & 0.5 & 0.9 & 0.7 & 0.7 & 0.7 & 0.9 & 1.1 & 0.8 & 1 \\
\hline Er & 2.4 & 2.8 & 2.5 & 2.8 & 3.6 & 2.7 & 3.1 & 2.8 & 1.5 & 2.5 & 2.2 & 1.9 & 2 & 2.5 & 3.2 & 2.2 & 2.8 \\
\hline $\mathrm{Tm}$ & 0.38 & 0.44 & 0.39 & 0.44 & 0.56 & 0.42 & 0.47 & 0.43 & 0.23 & 0.4 & 0.33 & 0.29 & 0.31 & 0.39 & 0.49 & 0.33 & 0.43 \\
\hline $\mathrm{Yb}$ & 2.5 & 3 & 2.7 & 3.1 & 4 & 2.9 & 3.2 & 3 & 1.5 & 2.7 & 2.2 & 1.9 & 2.1 & 2.7 & 3.3 & 2.3 & 2.9 \\
\hline $\mathrm{Lu}$ & 0.42 & 0.5 & 0.45 & 0.52 & 0.7 & 0.48 & 0.55 & 0.5 & 0.26 & 0.45 & 0.36 & 0.32 & 0.35 & 0.45 & 0.53 & 0.37 & 0.49 \\
\hline $\mathrm{Hf}$ & 8 & 9.7 & 8.1 & 8.2 & 17.7 & 8.9 & 11.2 & 9.3 & 3 & 5.2 & 6.6 & 2.7 & 5.7 & 9.9 & 5 & 7.3 & 6.2 \\
\hline $\mathrm{Ta}$ & 0.8 & 0.9 & 0.8 & 1 & 1 & 1 & 0.9 & 0.9 & 0.5 & 0.8 & 0.7 & 0.7 & 0.7 & 1 & 1.3 & 0.7 & 1 \\
\hline $\mathrm{Tl}$ & 0.3 & 0.4 & 0.4 & 0.4 & 0.2 & 0.4 & 0.3 & 0.4 & 0.3 & 0.5 & 0.3 & 0.4 & 0.3 & 0.4 & 1 & 0.3 & 0.6 \\
\hline $\mathrm{Pb}$ & 20 & 22 & 18 & 29 & 24 & 25 & 20 & 26 & 13 & 30 & 20 & 9 & 49 & 13 & 21 & 9 & 20 \\
\hline Th & 8.8 & 10.2 & 9.7 & 9.4 & 12.8 & 10.4 & 9.3 & 9.4 & 4.8 & 8.3 & 7.7 & 6.8 & 6.4 & 9.2 & 13.5 & 7 & 10.4 \\
\hline $\mathrm{U}$ & 2.3 & 2.6 & 2.8 & 2.7 & 3.2 & 2.7 & 2.6 & 2.9 & 1.5 & 2.5 & 2.7 & 1.9 & 1.7 & 2.6 & 3.8 & 2 & 2.8 \\
\hline
\end{tabular}


Appendix A. Continued.

\begin{tabular}{|c|c|c|c|c|c|c|c|c|c|c|c|c|c|c|}
\hline Core/ & core & core & core & core & core & core & core & core & core & core & core & core & core & core \\
\hline Surface & 02-05 & 02-05 & 02-05 & 02-05 & 02-05 & 02-05 & $02-05$ & $02-05$ & 02-05 & 02-05 & 02-05 & 02-05 & 02-05 & 02-05 \\
\hline Lithology & ss & ss & ss & st & st & st & ss & ss & ss & ss & st & ss & st & ss \\
\hline depth & 705 & 715 & 725 & 735 & 745 & 755 & 765 & 775 & 785 & 795 & 805 & 815 & 825 & 835 \\
\hline unit & lower & lower & lower & lower & lower & lower & lower & lower & lower & lower & lower & lower & lower & lower \\
\hline $\mathrm{SiO}_{2}$ & 711200 & 668900 & 681500 & 549600 & 537000 & 650100 & 566900 & 628600 & 554400 & 559900 & 578100 & 283900 & 658300 & 533700 \\
\hline $\mathrm{Al}_{2} \mathrm{O}_{3}$ & 88200 & 119500 & 107600 & 176700 & 196900 & 104000 & 168800 & 101900 & 184100 & 166200 & 154300 & 74600 & 108100 & 163200 \\
\hline $\mathrm{Fe}_{2} \mathrm{O}_{3}{ }^{(\mathrm{T})}$ & 32400 & 50100 & 42800 & 79300 & 89900 & 34500 & 77100 & 34500 & 86100 & 71600 & 64700 & 30900 & 42100 & 62800 \\
\hline $\mathrm{MnO}$ & 1240 & 870 & 1130 & 590 & 610 & 1730 & 730 & 1670 & 650 & 790 & 800 & 320 & 1510 & 1020 \\
\hline $\mathrm{MgO}$ & 11200 & 16200 & 14900 & 28100 & 28700 & 15500 & 27600 & 17500 & 31800 & 32000 & 33300 & 17700 & 21400 & 48400 \\
\hline $\mathrm{CaO}$ & 59900 & 37900 & 48500 & 23800 & 15300 & 76600 & 29400 & 85300 & 15800 & 37100 & 42100 & 223900 & 59600 & 42500 \\
\hline $\mathrm{Na}_{2} \mathrm{O}$ & 16300 & 13300 & 14300 & 9600 & 9000 & 13400 & 10100 & 12500 & 9400 & 10500 & 10800 & 5700 & 13600 & 9000 \\
\hline $\mathrm{K}_{2} \mathrm{O}$ & 16500 & 26900 & 22700 & 45400 & 50400 & 21100 & 42000 & 21000 & 44400 & 39400 & 36100 & 16800 & 21800 & 38200 \\
\hline $\mathrm{TiO}_{2}$ & 4780 & 7340 & 6460 & 8200 & 8530 & 6750 & 8390 & 6120 & 8920 & 8560 & 7840 & 3910 & 6990 & 8050 \\
\hline $\mathrm{P}_{2} \mathrm{O}_{5}$ & 1100 & 1300 & 1300 & 1600 & 1700 & 1300 & 1500 & 1200 & 1400 & 1600 & 1400 & 800 & 1400 & 1500 \\
\hline LOI & 61800 & 55400 & 60100 & 68300 & 64800 & 82400 & 68400 & 92000 & 62500 & 75100 & 76100 & 81600 & 71900 & 91200 \\
\hline $\mathrm{Sc}$ & 7 & 11 & 10 & 19 & 21 & 9 & 17 & 9 & 19 & 17 & 15 & 7 & 10 & 18 \\
\hline $\mathrm{Be}$ & 1 & 2 & 2 & 3 & 4 & 2 & 3 & 2 & 3 & 3 & 3 & 1 & 2 & 3 \\
\hline $\mathrm{V}$ & 54 & 84 & 66 & 146 & 156 & 69 & 142 & 73 & 147 & 130 & 117 & 48 & 77 & 138 \\
\hline $\mathrm{Ba}$ & 358 & 335 & 654 & 460 & 477 & 307 & 497 & 666 & 460 & 408 & 581 & 214 & 360 & 440 \\
\hline $\mathrm{Sr}$ & 267 & 108 & 223 & 123 & 133 & 124 & 152 & 432 & 117 & 134 & 359 & 701 & 201 & 166 \\
\hline $\mathrm{Y}$ & 24 & 28 & 25 & 29 & 28 & 28 & 28 & 28 & 27 & 29 & 29 & 15 & 30 & 30 \\
\hline $\mathrm{Zr}$ & 223 & 309 & 273 & 146 & 155 & 282 & 168 & 384 & 176 & 179 & 200 & 92 & 269 & 198 \\
\hline $\mathrm{Cr}$ & 50 & 80 & 70 & 100 & 120 & 80 & 110 & 80 & 120 & 110 & 100 & 50 & 80 & 110 \\
\hline Co & 9 & 14 & 13 & 21 & 24 & 11 & 21 & 11 & 23 & 20 & 18 & 4 & 11 & 23 \\
\hline $\mathrm{Zn}$ & 50 & 80 & 70 & 110 & 120 & 70 & 110 & 70 & 120 & 120 & 110 & 70 & 70 & 200 \\
\hline $\mathrm{Ga}$ & 10 & 15 & 13 & 22 & 27 & 13 & 23 & 13 & 25 & 22 & 19 & 10 & 14 & 22 \\
\hline $\mathrm{Ge}$ & 2 & 2 & 2 & 2 & 3 & 2 & 2 & 2 & 2 & 2 & 2 & 1 & 2 & 2 \\
\hline $\mathrm{Rb}$ & 56 & 93 & 78 & 149 & 176 & 75 & 148 & 75 & 164 & 142 & 127 & 62 & 80 & 138 \\
\hline $\mathrm{Nb}$ & 10 & 14 & 13 & 16 & 17 & 14 & 17 & 12 & 20 & 18 & 16 & 9 & 15 & 16 \\
\hline Sn & 1 & 2 & 2 & 4 & 4 & 2 & 3 & 2 & 4 & 3 & 3 & 1 & 2 & 4 \\
\hline Cs & 2.8 & 5.2 & 4.2 & 9.8 & 10.6 & 4.2 & 9.2 & 4.4 & 10 & 8.6 & 7.5 & 3.8 & 4.7 & 8.8 \\
\hline $\mathrm{La}$ & 23.8 & 37.7 & 31.5 & 44.1 & 50.5 & 30 & 46.8 & 31.1 & 48.7 & 43.8 & 35.6 & 18.8 & 33.6 & 39.6 \\
\hline $\mathrm{Ce}$ & 48.7 & 76.2 & 63.4 & 84.1 & 100 & 62.1 & 90.8 & 63.6 & 93.1 & 85 & 70.1 & 36.3 & 71.5 & 79.3 \\
\hline $\operatorname{Pr}$ & 6.1 & 8.66 & 7.33 & 9.3 & 11.1 & 7.53 & 10.2 & 7.46 & 10.4 & 9.71 & 8.1 & 4.23 & 8.49 & 8.99 \\
\hline $\mathrm{Nd}$ & 23.3 & 30.2 & 26.3 & 34.4 & 37.2 & 28 & 33.9 & 27.6 & 34.9 & 34 & 28.6 & 14.6 & 31.4 & 31.9 \\
\hline $\mathrm{Sm}$ & 5.5 & 6.1 & 5.7 & 6.2 & 6.6 & 6.1 & 6.4 & 6.3 & 6.4 & 6.8 & 5.9 & 3 & 6.7 & 6.5 \\
\hline $\mathrm{Eu}$ & 1.16 & 1.21 & 1.19 & 1.29 & 1.33 & 1.27 & 1.29 & 1.19 & 1.33 & 1.38 & 1.22 & 0.6 & 1.24 & 1.32 \\
\hline $\mathrm{Gd}$ & 4.8 & 5.2 & 4.9 & 5.4 & 5.3 & 5.5 & 5.2 & 5.3 & 5.4 & 5.7 & 5.2 & 2.5 & 5.8 & 5.4 \\
\hline $\mathrm{Tb}$ & 0.8 & 0.9 & 0.8 & 0.9 & 0.9 & 0.9 & 0.9 & 0.9 & 0.9 & 1 & 0.9 & 0.4 & 0.9 & 0.9 \\
\hline Dy & 4.4 & 5 & 4.6 & 5.2 & 5.3 & 5 & 5.2 & 4.9 & 5.5 & 5.6 & 5 & 2.5 & 5.5 & 5.2 \\
\hline Ho & 0.8 & 1 & 0.9 & 1 & 1.1 & 1 & 1 & 1 & 1.1 & 1.1 & 1 & 0.5 & 1.1 & 1 \\
\hline Er & 2.2 & 2.9 & 2.5 & 2.9 & 3.1 & 2.8 & 3 & 2.8 & 3.3 & 3.2 & 2.8 & 1.4 & 3.1 & 2.9 \\
\hline $\mathrm{Tm}$ & 0.34 & 0.44 & 0.39 & 0.45 & 0.47 & 0.42 & 0.45 & 0.41 & 0.5 & 0.48 & 0.43 & 0.22 & 0.46 & 0.44 \\
\hline $\mathrm{Yb}$ & 2.3 & 3 & 2.6 & 3 & 3.2 & 2.9 & 3 & 2.8 & 3.4 & 3.2 & 2.9 & 1.5 & 3.2 & 3 \\
\hline $\mathrm{Lu}$ & 0.37 & 0.49 & 0.44 & 0.49 & 0.55 & 0.49 & 0.52 & 0.48 & 0.56 & 0.54 & 0.51 & 0.25 & 0.54 & 0.51 \\
\hline $\mathrm{Hf}$ & 6.2 & 9 & 7.6 & 4.3 & 4.6 & 8.4 & 5.1 & 11 & 5.6 & 5.6 & 5.7 & 2.8 & 7.9 & 5.8 \\
\hline $\mathrm{Ta}$ & 0.7 & 1 & 0.9 & 1 & 1.2 & 1 & 1.2 & 0.9 & 1.3 & 1.2 & 1.1 & 0.6 & 1 & 1.1 \\
\hline $\mathrm{Tl}$ & 0.3 & 0.4 & 0.4 & 0.7 & 0.8 & 0.3 & 0.7 & 0.4 & 0.7 & 0.6 & 0.6 & 0.3 & 0.4 & 0.6 \\
\hline $\mathrm{Pb}$ & 11 & 22 & 20 & 29 & 27 & 17 & 31 & 17 & 26 & 31 & 30 & 17 & 19 & 33 \\
\hline Th & 6.7 & 9.6 & 8.3 & 11.3 & 12.7 & 8.6 & 11.7 & 9.3 & 13.3 & 11.9 & 10.4 & 5.3 & 9 & 11 \\
\hline $\mathrm{U}$ & 1.9 & 2.9 & 2.4 & 3.3 & 3.5 & 2.6 & 4 & 2.7 & 3.6 & 3.4 & 3.1 & 1.6 & 2.7 & 3.4 \\
\hline
\end{tabular}

Notes: data in ppm; ss = sandstone; st = siltstone or finer grained. 